Monitoring Surveys of the New Haven

Capping Project,

$1993-1994$

\title{
Disposal Area
}

Monitoring System

DAMOS
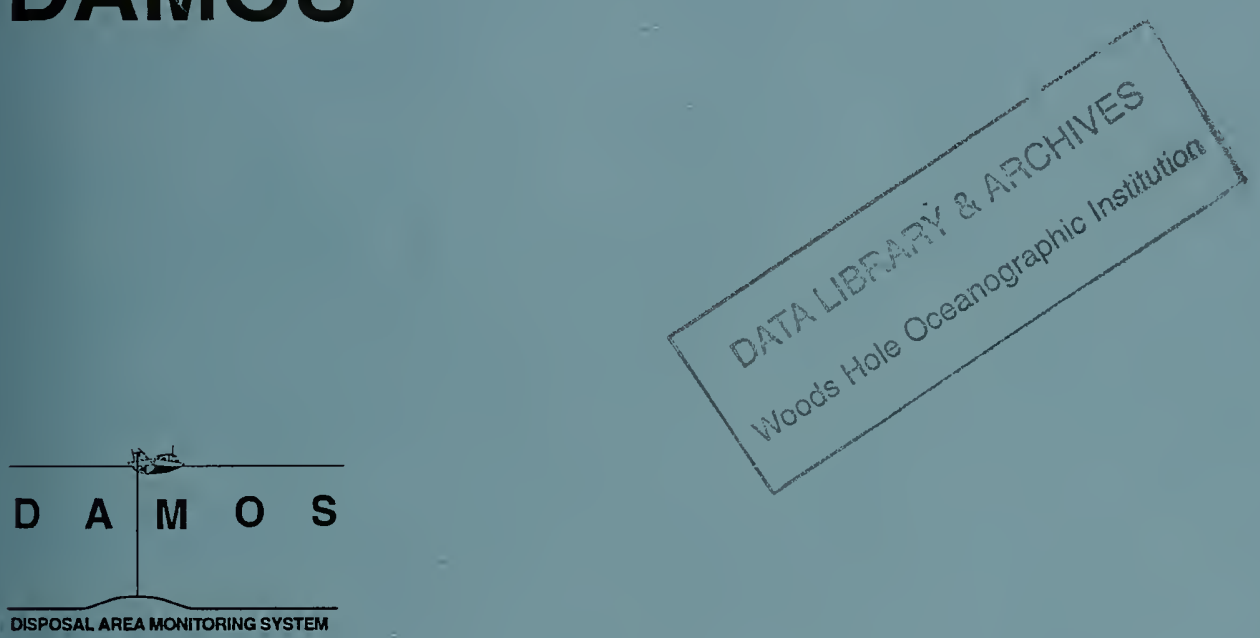

Contribution 111

July 1996

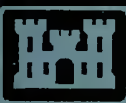

US Army Corps

of Engineers

New England Division

TC

187

D57

no. 111 


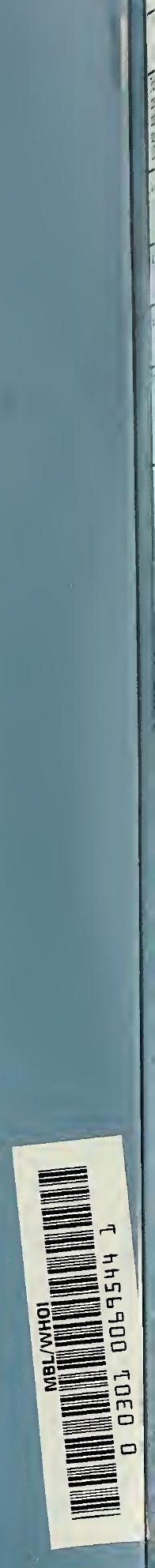


Public reporting concern for the collection of information is estimated to average l hour per persons inculding the time for reviewing instructions, searching exsisting data sources, gathering and measuring data needed and correcting and reviewing the collection of information. Send comments regarding this burden estimate or any other aspect of this collectikon of information including suggestions for reducing this burden to Washington Headquaters Services, Directoriate for Information Observations and Records, 1216 Jefferson Davis Highway, Suite 1204, Arlington VA 22202-4302 and to the Office of Management and Support.

\begin{tabular}{|l|l|c|}
\hline 1. AGENCY USE ONLY (LEAVE BLANK) & $\begin{array}{c}\text { 2. REPORT DATE } \\
\text { July } 1996\end{array}$ & $\begin{array}{c}\text { 3. REPORT TYPE AND DATES } \\
\text { Final Report }\end{array}$ \\
\hline
\end{tabular}

4. TITLE AND SUBTITLE

MONITORING SURVEYS OF THE NEW HAVEN CAPPING PROJECT, 1993-1994

6. FUNDING NUMBERS

6. AUTHORS

John T. Morris, Judith Charles, and David C. Inglin

\section{PERFROMING ORGANIZATION NAME(S) AND ADDRESS(ES)}

Science Applications Intenational Corporation

221 Thrid Street

Newport, RI 02840

8. PERFORMING

ORGANIZATION REPORT

SAIC No. 319

9. SPONSORING/MONITORING AGENCY NAMES(S) AND ADDRESS(ES)

US Army Corps of Engineers-New England Division

424 Trapelo Road

Waltham, MA 02254-9149
10. SPONSORING/

MONITORING AGENCY

DAMOS Contribution

Number 111

11. SUPPLEMENTARY NOTES Avaiable from: DAMOS PROGRAMMANAGER Regulatory Division, USACE-NED 424 Trapelo Road Waltham, MA 02254-9149

12a. DISTRIBUTION/AVAIABILTY STATEMENT

Approved for public release; distribution unlimited

12b. DISTRIBUTION CODE

\section{ABSTRACT}

Dredging of the New Haven Harbor Channel and five private marine terminals occurred between October 1993 and February 1994. These projects involved removal of an estimated barge volume of $500,000 \mathrm{~m} 3$ of unacceptably contaminated dredged material (UDM) from the inner portion of the federal channel and about $90,000 \mathrm{~m} 3$ from the five private terminals. The UDM was approved for open water disposal and sediment capping at Central Long Island Sound Disposal Site (CLIS). A total barge volume of $569,000 \mathrm{~m} 3$ ( $506,000 \mathrm{~m} 3$ federal and $63,000 \mathrm{~m} 3$ private) of cap dredged material (CDM) was used to establish a sediment cap over the UDM deposit.

A taut-wired, moored Disposal Area Monitoring System (DAMOS) disposal buoy "NHAV" was deployed in the center of a basin-like feature created by a ring of seven historical disposal mounds. The ring of mounds, which requried ten years to construct, would serve as a lateral containment measure, limiting the spread of the initial UDM deposit and facilitating efficient capping operations. Capping material was placed at various points surrounding the NHAV buoy to ensure sufficient coverage of the UDM mound. The end result of disposal activity at CLIS was the development of a flat, stable, confined aquatic disposal (CAD) mound.

Science Applications International Corporation (SAIC) completed five precesion bathymetric surveys (baseline, interim disposal, precap, interim cap, and postcap), two Remote Monitoring of the Seafloor (REMOTS) surveys, and three geotechnical coring surveys of the NHAV 93 mound. The strategic repetition of the survey activity over the NHAV 93 mound has given the SAIC and NED an excellent perspective on $\mathrm{CAD}$ mound development and insight toward the disposal and oceanographic processes that affect the bottom feature. The bathymetric data provided "snapshots" of the developing mounds, allowing time-series comparisons of the various stages of CAD mound construction. The REMOTS photographs were used to determine relative shear strength of the containment ring as well as the areal extent of the UDM deposit. Geotechnical cores and grab samples were used to define the physical characteristics, document the bulk density, and estimate the consolidation of the NHAV93 mound.

Comparisons between the baseline, interim disposal, and precap monitoring surveys revealed a UDM deposit $510 \mathrm{~m}$ in diameter and $2.5 \mathrm{~m}$ in height, containing a volume of $312,000 \mathrm{~m} 3$ of new material. A significant amount of consolidation was detected over the apex of the disposal mound before capping operations commenced. The NHAV 93 mound was then capped to a thickness of 0.5 to $1.0 \mathrm{~m}$ with CDM from the outer harbor, resulting in a total mound diameter of $600-800 \mathrm{~m}$ and height of 2.5 at the apex. Volume difference calculations based on the baseline, precap, interim cap, and the postcap surveys detected $402,000 \mathrm{~m} 3$ of cap material overlying the initial UDM deposit and a total mound volume of $714,000 \mathrm{~m} 3$.

Although 402,000m 3 of CDM was placed over the initial UDM mound, there was no increase in net mound height at the apex. It has been determined through precision bathymetric surveying and geotechnical coring that consoildation of the UDM deposit and compaction of the basement sediments had occurred during the middle stages of CAD mound construction. As a result, no apparent changes in the mound height were detected after the completion of capping operations over the NHAV 93 mound.

Monitoring of NHAV 93 mound has continued through 1995. The long-term focus of these operations has pertained to mound stabilty and compaction/consoildation of the NHAV 93 mound; REMOTS sediment-profile surveys have determined the recolonization rate of the mound; and additional sediment cores and grab samples investigated the potential for migration of contaminents into overlying cap material. The results of these datasets have been submitted to NED under seperate DAMOS report titles.

Central Long Island Sound (CLIS), Capping , bathymetric survey , Remote Monitoring of the Seafloor

(REMOTS), open water disposal, dredged material 


\section{MONITORING SURVEYS \\ OF THE NEW HAVEN CAPPING PROJECT, \\ 1993 - 1994}

CONTRIBUTION \#111

July 1996

Report No.

SAIC Report No. 319

Submitted to:

Regulatory Division

New England Division

U.S. Army Corps of Engineers

424 Trapelo Road

Waltham, MA 02254-9149

Prepared by:

John T. Morris

Judith Charles

David C. Inglin

Submitted by:

Science Applications International Corporation

Admiral's Gate

221 Third Street

Newport, RI 02840

(401) $847-4210$ 


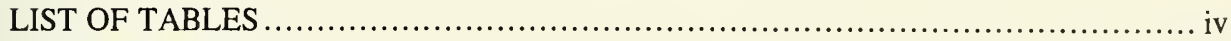

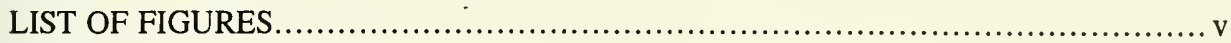

EXECUTIVE SUMMARY ........................................................... vii

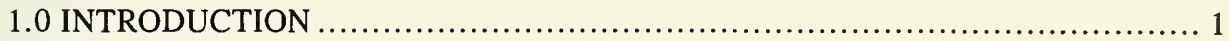

2.0 DECISION PROCESS FOR THE DREDGING OF NEW HAVEN HARBOR ....... 10

2.1 Physical Testing of Sediment ........................................... 10

2.2 Chemical Testing of Sediment.............................................. 12

2.2.1 Metals ........................................................ 12

2.2.2 Organic Compounds .......................................... 12

2.3 Bioaccumulation/Bioassay Tests ...................................... 14

2.4 Disposal and Capping Operations....................................... 15

2.4.1 Disposal of UDM ........................................... 15

2.4.2 Capping Operations ........................................... 15

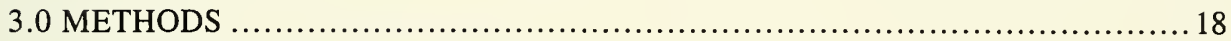

3.1 Precision Bathymetric Surveys ......................................... 18

3.2 REMOTS ${ }^{\circledR}$ Sediment-Profile Surveys ......................................... 19

3.2.1 Baseline Survey ................................................ 19

3.2.2 Precap Survey................................................. 21

3.3 Geotechnical Cores/Surface Grabs ...................................... 21

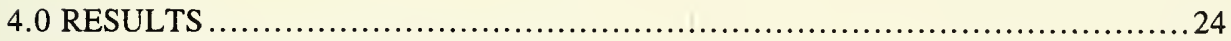

4.1 Repetitive Bathymetric Surveys ....................................... 24

4.1.1 Baseline Survey (19-20 September 1993) ......................... 24

4.1.2 Interim Disposal Survey (23-25 October 1993) .....................24

4.1.3 Precap Survey (2-3 November 1993) .............................227

4.1.4 Interim Cap Surveys (23-24 November 1993 and

12-13 January 1994) ........................................... 32

4.1.5 Postcap Survey (13-14 March 1994) ............................. 32

4.2 REMOTS $^{\circledR}$ Sediment-Profile Surveys ...................................... 41

4.2.1 Grain Size Distribution ....................................... 41

4.2.2 Prism Penetration Depth ....................................... 41

4.2.3 Mean Apparent Redox Potential Discontinuity (RPD) Depth ......... 42

4.2.4 Infaunal Successional Stage......................................... 42

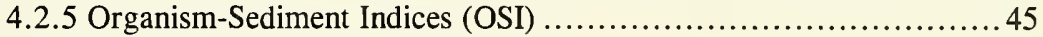




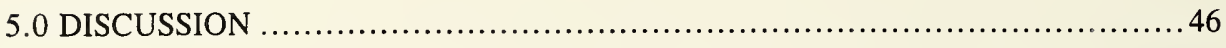

6.0 CONCLUSIONS ........................................................ 54

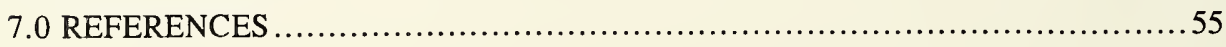

INDEX

APPENDICES 
Table 1-1. Summary of Monitoring Surveys for the New Haven Capping Project, September 1993 to March 1994

Table 1-2. Amounts of Sediments Dredged from New Haven Harbor, October 1993 to February 1994.

Table 2-1. New England River Basins Commission (NERBC) Classification of Dredged Sediment 13

Table 4-1. Summary of Volume Difference Calculations for the New Haven Capping Project, September 1993 to March 1994 

Figure 1-1. Location of the federal navigation channel, Gulf Oil, Mobil Oil Corporation, the New Haven Terminal, Northeast Petroleum, and Wyatt Incorporated in New Haven Harbor

Figure 1-2. Timeline of disposal and environmental monitoring activity during the New Haven Capping Project 1993-1994 ….............................. 3

Figure 1-3. Location of the Central Long Island Sound Disposal Site (CLIS) ............ 7

Figure 1-4. Location of the NHAV buoy over the basin created by seven historic disposal mounds

Figure 2-1. Sediment and benthic sampling locations in the federal navigation channel, New Haven Harbor

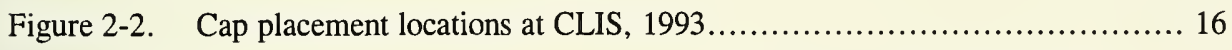

Figure 3-1. Station replicate locations for the baseline REMOTS ${ }^{\circledR}$ sediment-profile survey conducted 21-22 September 1993

Figure 3-2. Station locations for the precap REMOTS ${ }^{\circledR}$ sediment-profile survey conducted 4 November 1993 with dredged material thickness seen in REMOTS ${ }^{\circledR}$ analysis and $0.5 \mathrm{~m}$ contour from bathymetry

Figure 4-1. Contoured bathymetric chart around the disposal point following disposal of $50 \%$ of the sediments for the federal inner harbor dredging project, October 1993 (depth in meters) 25

Figure 4-2. Depth difference contour chart (in meters) based on the comparison of the interim disposal (October 1993) and baseline (September 1993) bathymetric surveys 26

Figure 4-3. Contoured bathymetric chart of the mound complex at precap status or $100 \%$ completion of the dredging of the inner harbor sediments plus approximately 76,000 $\mathrm{m}^{3}$ of cap material, 2 November 1993 (depth in meters) 28 
Figure 4-4. Depth difference contour chart (in meters) based on the comparison of interim disposal (October 1993) and precap (November 1993) bathymetric surveys

Figure 4-5. Bathymetric profile plots of survey lane 35 from the interim disposal survey (October 1993) and precap survey (November 1993)

Figure 4-6. Depth difference contour chart (in meters) based on the comparison of the precap (2 November 1993) and baseline (September 1993) bathymetric surveys

Figure 4-7. Contoured bathymetric chart of the mound complex following completion of $50 \%$ of the capping operations, 23 November 1993 (depth in meters)..... 33

Figure 4-8. Contoured bathymetric chart based on data collected by Ocean Surveys, Inc. at the completion of the private dredging operations, January 1994 (depth in meters)

Figure 4-9. Depth difference contour chart (in meters) based on the comparison of the interim cap (23 November 1993) and precap (2 November 1993) bathymetric surveys

Figure 4-10. Depth difference contour chart (in meters) based on the comparison of the Ocean Surveys, Inc. interim cap (January 1994) and SAIC baseline (September 1993) bathymetric surveys

Figure 4-11. Depth difference contour chart (in meters) based on the comparison of the SAIC precap survey (2 November 1993) and the Ocean Surveys, Inc. interim cap survey (January 1994)

Figure 4-12. Contoured bathymetric chart of the mound complex following completion of the capping operations (postcap), March 1994

Figure 4-13. Depth difference contour chart (in meters) based on the comparison of the postcap (March 1994) versus baseline (September 1993) bathymetric surveys 
Figure 4-14. Depth difference contour chart showing apparent cap material thickness (in meters) based on the comparison of the postcap (March 1994) versus precap (2 November 1993) surveys

Figure 4-15. Mean RPD and OSI values for the five disposal mounds and the east-southeast valley feature during the baseline REMOTS ${ }^{\circledR}$ survey

Figure 4-16. Infaunal successional stages at the five disposal mounds and eastsoutheast valley feature during the baseline REMOTS ${ }^{\circledR}$ survey....

Figure 5-1. Suggested pattern of future disposal at CLIS to maximize site capacity and construct a network of containment cells 48

Figure 5-2. July 1994 subbottom data. Contour plot of subbottom layer 1 (cap thickness) $1600 \times 525 \mathrm{~m}$ analysis area over the NHAV 93 mound, $0.25 \mathrm{~m}$ contour interval.

Figure 5-3. July 1994 subbottom data. Contour plot of subbottom layer 1 (cap thickness) overlaid onto cap material footprint plot of March 1994, $1600 \times 525 \mathrm{~m}$ analysis area over the NHAV 93 mound. 

Dredging of the New Haven Harbor Channel and five private marine terminals occurred between October 1993 and February 1994. These projects involved removal of an estimated barge volume of $500,000 \mathrm{~m}^{3}$ of unacceptably contaminated dredged material (UDM) from the inner portion of the federal channel and about $90,000 \mathrm{~m}^{3}$ from the five private terminals. The UDM was approved for open water disposal and sediment capping at the Central Long Island Sound Disposal Site (CLIS). A total barge volume of $569,000 \mathrm{~m}^{3}$ $\left(506,000 \mathrm{~m}^{3}\right.$ federal and $63,000 \mathrm{~m}^{3}$ private) of cap dredged material (CDM) was used to establish a sediment cap over the UDM deposit.

A taut-wired, moored Disposal Area Monitoring System (DAMOS) disposal buoy "NHAV" was deployed in the center of a basin-like feature created by a ring of seven historic disposal mounds. The ring of mounds, which required ten years to construct, would serve as a lateral containment measure, limiting the spread of the initial UDM deposit and facilitating efficient capping operations. Deposition of UDM from the federal project was completed at the NHAV buoy, while the privately dredged UDM was disposed at a point to the southwest of the buoy. Capping material was placed at various points surrounding the NHAV buoy to ensure sufficient coverage of the UDM mound. The end result of disposal activity at CLIS was the development of a flat, stable, confined aquatic disposal (CAD) mound.

The decision to cap the material was based on the results of the Ampelisca bioassay test using the sediments sampled from the federal channel project. Biological testing of the private marine terminal projects was not pursued due to a cooperative plan for capping both the federal and private projects, providing a cost-efficient method of disposal.

Science Applications International Corporation (SAIC) completed five precision bathymetric surveys (baseline, interim disposal, precap, interim cap, and postcap), two Remote Monitoring of the Seafloor (REMOTS ${ }^{\circledR}$ ) surveys, and three geotechnical coring surveys of the NHAV 93 mound. The strategic repetition of survey activity over the NHAV 93 mound has given SAIC and NED an excellent perspective on CAD mound development and insight toward the disposal and oceanographic processes that affect the bottom feature. The bathymetric data provided "snapshots" of the developing mounds, allowing time-series comparisons of the various stages of CAD mound construction. The REMOTS ${ }^{\circledR}$ photographs were used to determine the relative shear strength of the containment ring as well as the areal extent of the UDM deposit. Geotechnical cores and grab samples were used to define the physical characteristics, document the bulk density, and estimate the consolidation of the NHAV 93 mound. 
Comparisons between the baseline, interim disposal, and precap monitoring surveys revealed a UDM deposit $510 \mathrm{~m}$ in diameter and $2.5 \mathrm{~m}$ in height, containing a volume of $312,000 \mathrm{~m}^{3}$ of new material. A significant amount of consolidation was detected over the apex of the disposal mound before capping operations commenced. The NHAV 93 mound was then capped to a thickness of 0.5 to $1.0 \mathrm{~m}$ with CDM from the outer harbor, resulting in a total mound diameter of $600-800 \mathrm{~m}$ and height of $2.5 \mathrm{~m}$ at the apex. Volume difference calculations based on the baseline, precap, interim cap, and postcap surveys detected $402,000 \mathrm{~m}^{3}$ of cap material overlying the initial UDM deposit and a total mound volume of $714,000 \mathrm{~m}^{3}$.

Although $402,000 \mathrm{~m}^{3}$ of CDM was placed over the initial UDM mound, there was no increase in net mound height at the apex. It has been determined through precision bathymetric surveying and geotechnical coring that consolidation of the UDM deposit and compaction of the basement sediments had occurred during the middle stages of CAD mound construction. As a result, no apparent changes in mound height were detected after the completion of capping operations over the NHAV 93 mound.

Monitoring of the NHAV 93 mound has continued through 1995, including additional precision bathymetric surveys, subbottom profiling, REMOTS ${ }^{\circledR}$ sediment-profile photography, sediment surface grab samples for chemical analysis, and geotechnical coring. The long-term focus of these operations has pertained to mound stability and compaction/consolidation of the NHAV 93 mound; REMOTS ${ }^{\circledR}$ sediment-profile surveys have determined the recolonization rate of the mound; and additional sediment cores and grab samples investigated the potential for migration of contaminants into the overlying cap material. The results of these datasets have been submitted to NED under separate DAMOS report titles. 


\subsection{INTRODUCTION}

From October 1993 to February 1994, the New Haven Harbor was dredged to improve navigational access within the federal channel and operations efficiency at five area marine terminals (Figure 1-1). As part of the Dredged Material Management Plan, formulated by the New England Division (NED) of the US Army Corps of Engineers (USACE), the federal channel project sediments were sampled and subjected to a variety of tests to determine their physical and chemical properties. The results of a standard Ampelisca bioassay test indicated that the federal channel project material was not suitable for unconfined open water disposal and required capping. Capping is a subaqueous containment method which uses dredged material determined to be suitable for unconfined open water disposal to overlay and isolate the unacceptably contaminated dredged material (UDM) from the environment (Fredette 1994). The process was introduced to the Central Long Island Sound Disposal Site (CLIS) in 1979 with the formation of the Stamford-New Haven mounds (STNH-N and STNH-S; SAIC 1995).

Subaqueous capping is the most cost effective and environmentally sound approach to manage large volumes of UDM. Results of the Stamford-New Haven Project suggested that careful navigational controls and point deposition techniques at a taut-wired buoy could be used to form a discrete mound of UDM (SAIC 1995). In addition, these results suggested that precise deposition of cap dredged material (CDM), both at the center and at the flanks of the UDM mound, could be accomplished with tight navigational control and project planning. As a result of the operational success of the 1979 capping project, additional capping projects were conducted at CLIS. These include the Mill-Quinnipiac River mound (MQR), Norwalk mound (NORWALK), and two Experimental Cap Sites (CS-1 and CS-2). Physical monitoring of the mounds indicates that they have been stable even after the passage of three hurricanes (SAIC 1995).

A successful capping project requires an effective monitoring program in addition to predisposal planning and well-organized dredging and disposal operations (SAIC 1995). Science Applications International Corporation (SAIC) conducted a series of five environmental surveys including the collection of various types of data at each stage of the dredging project (Table 1-1). The data collected at CLIS includes precision bathymetry, Remote Ecological Monitoring of the Seafloor (REMOTS ${ }^{\circledR}$ ) sediment-profile photographs, sediment grab samples, and geotechnical cores (Figure 1-2). The strategic repetition of survey operations over the disposal site during the New Haven Capping Project provided SAIC and NED a wealth of information on the developing mound.

The baseline survey conducted from 19 to 20 September 1993 was intended to define the predisposal conditions at the site to provide a baseline for comparison to the future survey 


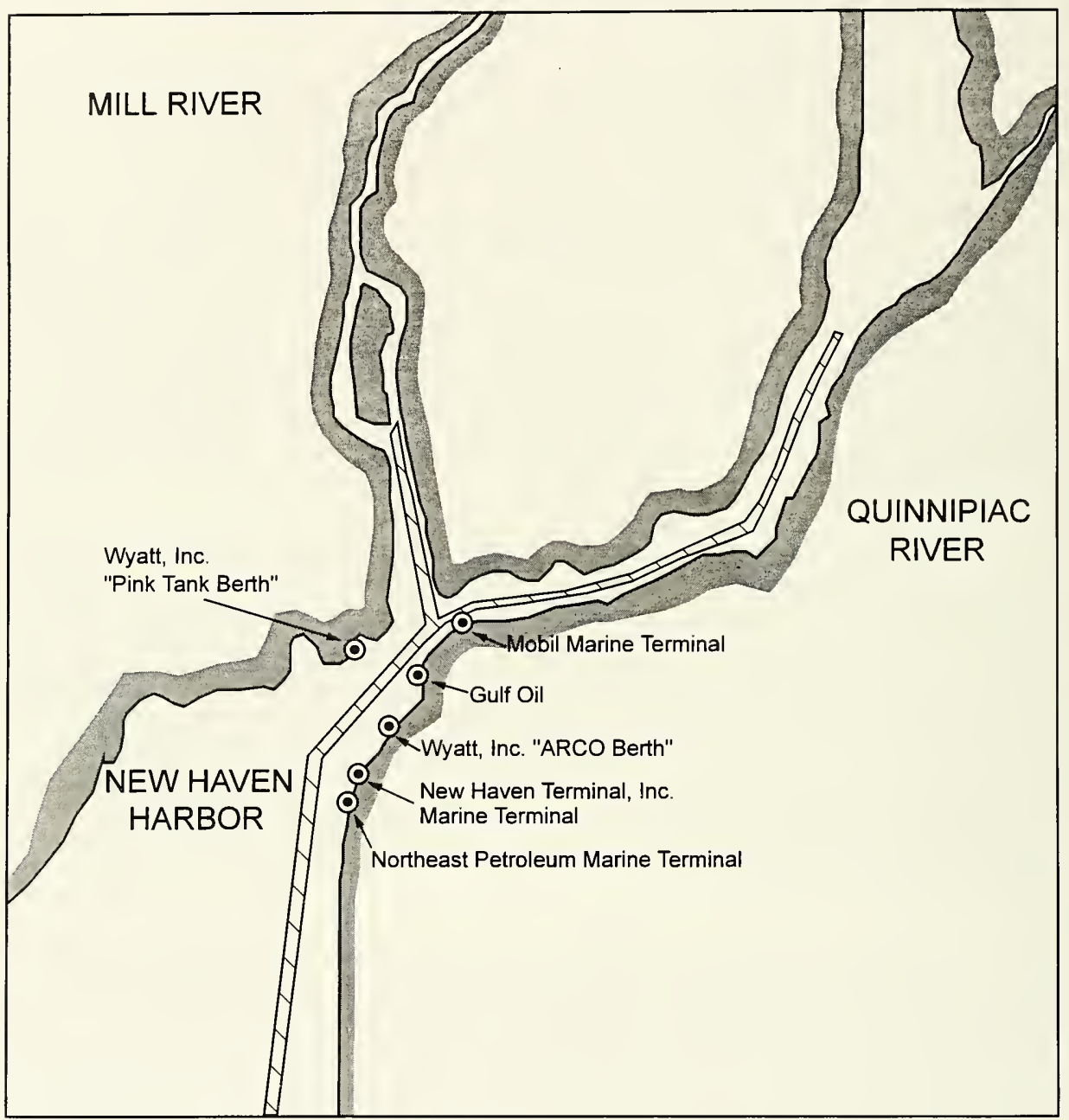

Figure 1-1. Location of the federal navigation channel, Gulf Oil, Mobil Oil Corporation, the New Haven Terminal, Northeast Petroleum, and Wyatt Incorporated in New Haven Harbor (adapted from HMM Associates, Inc. 1993) 


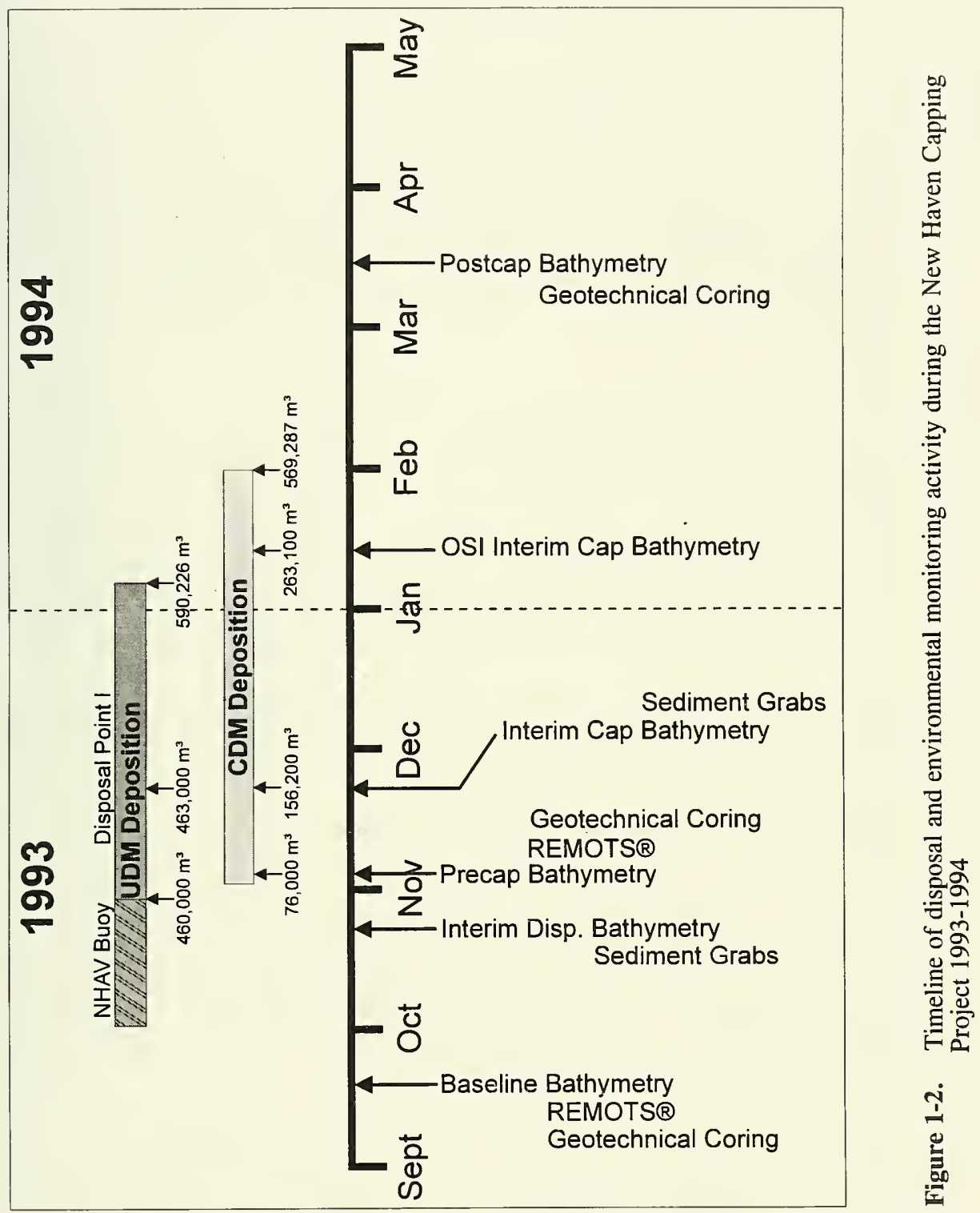


Summary of Monitoring Surveys for the New Haven Capping Project, September 1993 to March 1994

\begin{tabular}{|c|c|c|c|c|c|c|}
\hline Event & $\begin{array}{c}\text { Baseline } \\
\text { (Predisposal) }\end{array}$ & $\begin{array}{l}\text { Interim } \\
\text { Disposal }\end{array}$ & Precap* & $\begin{array}{l}\text { Interim } \\
\text { Cap }\end{array}$ & $\underset{\text { Cap }^{+}}{\text {Interim }}$ & Postcap \\
\hline $\begin{array}{l}\text { Precision } \\
\text { Bathymetry }\end{array}$ & $9 / 19-20 / 93$ & $10 / 23-25 / 93$ & $11 / 2-3 / 93$ & $\begin{array}{l}11 / 23 \\
24 / 93\end{array}$ & $1 / 12-13 / 94$ & $3 / 13-14 / 94$ \\
\hline $\begin{array}{l}\text { REMOTS } \\
\text { Sediment } \\
\text { Profile }\end{array}$ & $9 / 21-22 / 94$ & & $11 / 4 / 93$ & & & \\
\hline $\begin{array}{l}\text { Sediment } \\
\text { Cores }\end{array}$ & $9 / 21 / 93$ & & $11 / 10 / 93$ & & & $3 / 15 / 94$ \\
\hline $\begin{array}{l}\text { Sediment } \\
\text { Grabs }\end{array}$ & & $10 / 25 / 93$ & & $11 / 24 / 93$ & & \\
\hline Vessel & $\begin{array}{l}\mathrm{M} / \mathrm{V} \\
\text { Beavertail }\end{array}$ & $\begin{array}{l}\mathrm{R} / \mathrm{V} \\
\text { UCONN }\end{array}$ & $\begin{array}{l}\mathrm{R} / \mathrm{V} \\
\text { UCONN }\end{array}$ & $\begin{array}{l}\mathrm{M} / \mathrm{V} \\
\text { Beavertail }\end{array}$ & & $\begin{array}{l}\mathrm{M} / \mathrm{V} \\
\text { Beavertail }\end{array}$ \\
\hline
\end{tabular}

data. The baseline survey included bathymetry, REMOTS ${ }^{\circledR}$, and geotechnical cores. The interim disposal survey, completed after 50\% of the UDM dredged from the federal channel was disposed (23-25 October 1993), included bathymetry and sediment grab samples.

Bathymetry, REMOTS ${ }^{\circledR}$, and geotechnical cores were collected during the precap survey, performed following the completion of the federal inner harbor dredging (2-3 November 1993). This survey was designed to provide an accurate map of the distribution of UDM to facilitate complete cap coverage. An interim capping survey was completed from 23 to 24 November 1993 using bathymetry and sediment grab samples to document the distribution of cap material. A final survey was conducted following the completion of all dredging activities to evaluate the coverage of the UDM deposit by the outer harbor CDM. This postcap survey included bathymetry and geotechnical cores and was completed from 13 to 15 March 1994.

The geotechnical cores were collected by SAIC and University of Rhode Island (URI) scientists in close proximity to the NHAV disposal buoy and within the central portion of the dredged material mound. Results provided an estimate of consolidation within the basement sediments and inner harbor dredged material. In addition, the geotechnical coring results 
were used to verify the completion of the cap material thickness requirements established by NED.

A sediment plume study was conducted during the initial phase of dredging ( 25 October to 18 November 1993) to monitor the potential for material dispersion (Bohlen et al. 1994). Nine plume tracking surveys were conducted by Dr. W.F. Bohlen of the University of Connecticut while Great Lakes Dredging Company was operating in New Haven Harbor; results will be provided under a separate report. Further survey activity over CLIS during the New Haven Capping Project included bathymetric and sediment-profile photography surveys (12-13 January 1994). Ocean Surveys, Incorporated completed these field tasks following the disposal of UDM generated from the private marine terminal projects in the harbor.

Since 1977, monitoring cruises have been conducted at CLIS as part of the Disposal Area Monitoring System (DAMOS) Program for the US Army Corps of Engineers, NED (NUSC 1979). These surveys assessed both the stability of the dredged material disposed at the site and any potential for adverse long-term environmental effects, particularly in terms of the postdisposal recovery of benthic ecosystems. The objectives of these surveys included documenting and monitoring the location and physical characteristics of dredged material mounds, as well as any postdepositional dispersion of material. A total of eighteen inactive disposal mounds currently exist within the $6.85 \mathrm{~km}^{2}$ area of CLIS.

CLIS, located approximately 5.6 nautical miles (nmi) south of South End Point, East Haven, Connecticut, continues to be one of the most active containment sites in New England (Figure 1-3). The $2 \mathrm{nmi}$ long by $1 \mathrm{nmi}$ wide rectangular area, centered at $41^{\circ} 08.950^{\prime} \mathrm{N}, 72^{\circ} 52.850^{\prime} \mathrm{W}$, receives sediments dredged from the New Haven, Stamford, and Norwalk Harbors as well as adjacent coves and embayments. In addition, the large volumes of material deposited at CLIS have been subject to a variety of dredged material management strategies.

The strategy at CLIS during the 1993 New Haven Harbor Capping Project was to form a large scale, stable confined aquatic disposal (CAD) mound. A CAD mound is a dredged material disposal mound constructed in conjunction with artificial or natural containment measures. The containment measures are structures that surround a given area limiting the lateral spread of UDM to facilitate efficient sediment capping operations. The taut-wire moored buoy "NHAV" was deployed at $41^{\circ} 09.122^{\prime} \mathrm{N}$ and $72^{\circ} 53.453^{\prime} \mathrm{W}$, over the center of a basin created by the planned placement of seven historic disposal mounds: CLIS87, CLIS-88, CLIS-89, CLIS-90, CLIS-91, SP, and NORWALK (Figure 1-4). The basin region was utilized for the disposal of a total volume of $1,159,513 \mathrm{~m}^{3}$ of material; $590,229 \mathrm{~m}^{3}$ of UDM and $569,287 \mathrm{~m}^{3}$ of CDM (Table 1-2). The precision disposal and 
capping operations performed by the Great Lakes Dredging Company and the technical support provided by SAIC aided NED in forming a stable CAD mound with a diameter of $550 \mathrm{~m}$, a height of $2.5 \mathrm{~m}$, and a CDM to UDM ratio of 0.96 to 1.0 .

The successful completion of the NHAV 93 mound represents the end of a ten-year dredging cycle in the central Long Island Sound region. NED estimates that major maintenance dredging of New Haven Harbor must be conducted every ten years to provide adequate water depths for commercial, military, and private vessels utilizing the harbor. Thoughtful management of smaller volumes of dredged material over the last decade not only facilitated the safe disposal of over a million cubic meters of dredged material, but also demonstrated a management strategy that can serve to maximize the site capacity of CLIS as well as other DAMOS disposal sites. 

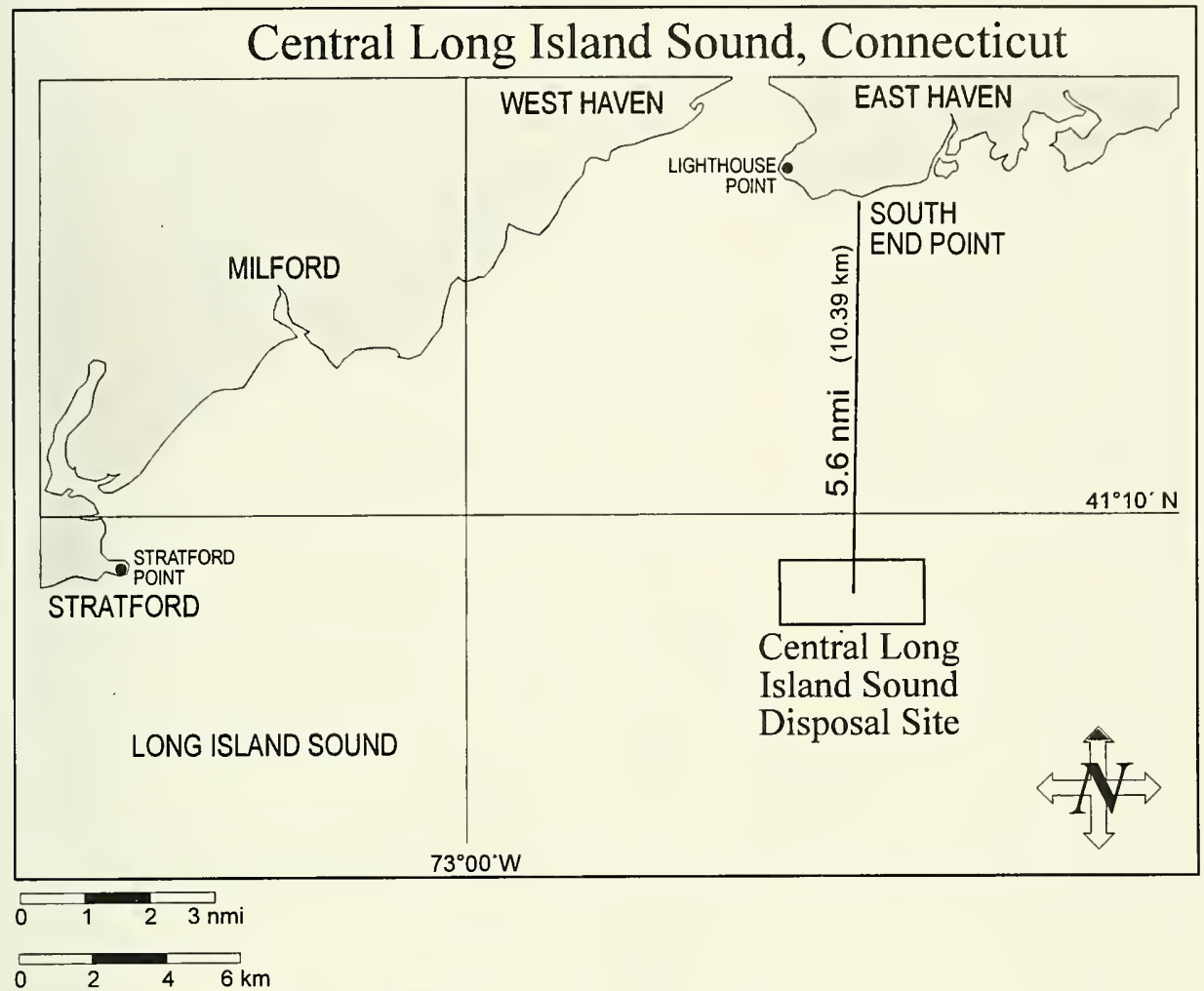

Figure 1-3. Location of the Central Long Island Sound Disposal Site (CLIS) 


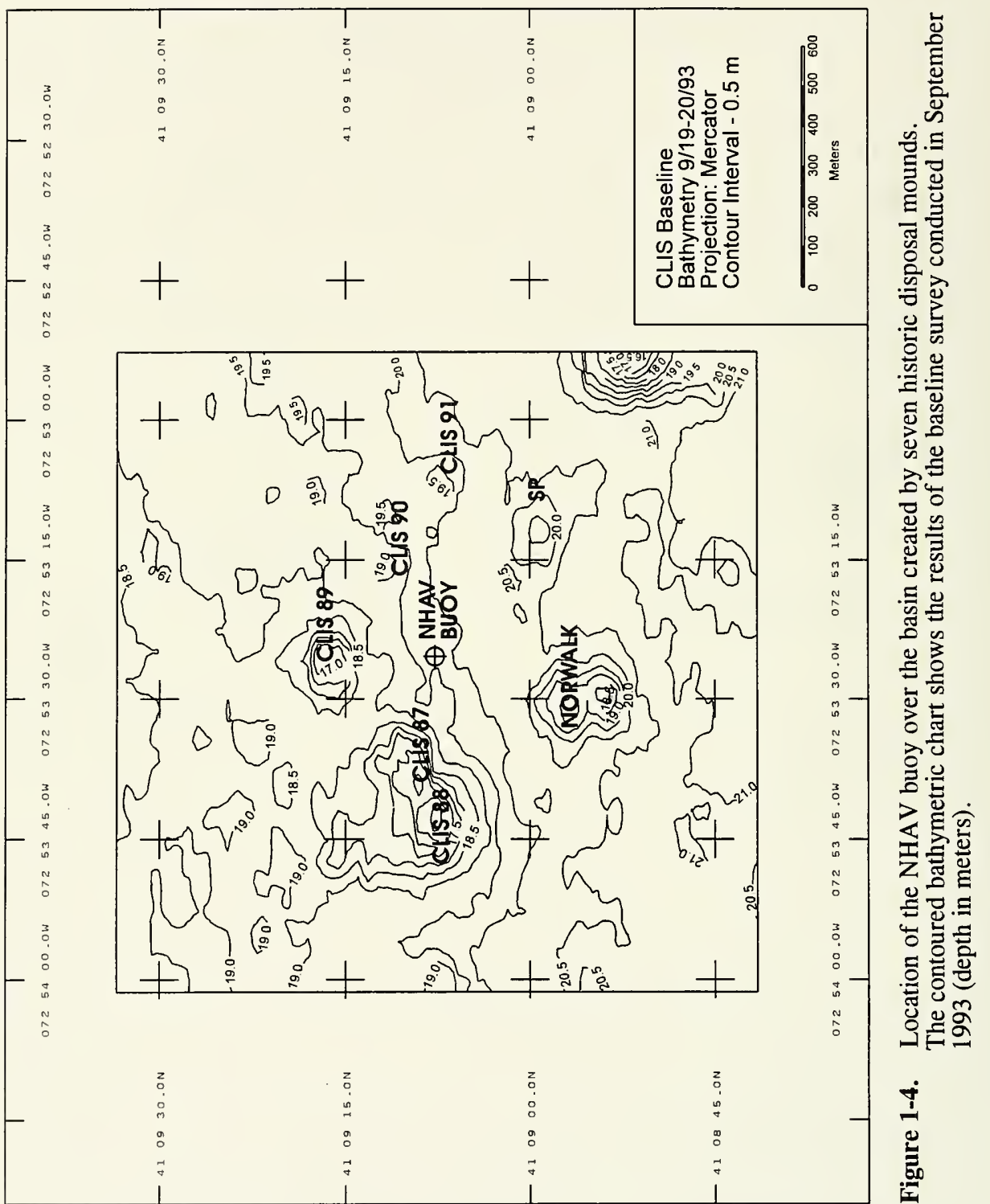


Table 1-2

Amounts of Sediments Dredged from New Haven Harbor, October 1993 to February 1994 (Source: DAMOS Disposal Barge Logs)

\section{A. CONTAMINATED SEDIMENTS}

\begin{tabular}{|llr|}
\hline Disposal Location & Source & Volume $\left.\mathbf{( m}^{\mathbf{3}}\right)$ \\
\hline NHAV buoy & inner federal channel & 460,083 \\
Disposal Point I & inner federal channel & 40,286 \\
Total from the inner federal channel & $\mathbf{5 0 0 , 3 6 9}$ \\
\hline Disposal Point I & & \\
& New Haven Terminal & 25,327 \\
& Wyatt Incorporated & 20,873 \\
& NE Petroleum & 11,927 \\
& Gulf Oil & 28,901 \\
& Mobil Oil & 2,829 \\
\cline { 2 - 3 } Total from private dredging projects & 89,857 \\
\cline { 2 - 3 } & TOTAL VOLUME & $\mathbf{5 9 0 , 2 2 6}$ \\
\cline { 2 - 3 } & &
\end{tabular}

\section{B. CAP SEDIMENTS}

\begin{tabular}{|clr|}
\hline Disposal Location & Source & Volume $\left.\mathbf{( m}^{\mathbf{3}}\right)$ \\
\hline Multiple Points & outer federal channel & 505,848 \\
K, L, V-Z, A1 & NE Petroleum & 48,338 \\
G & Lex Atlantic/Gateway & 12,272 \\
J & Wyat Incorporated & 2,829 \\
\hline & TOTAL VOLUME & $\mathbf{5 6 9 , 2 8 7}$ \\
\cline { 2 - 3 }
\end{tabular}




\subsection{DECISION PROCESS FOR THE DREDGING OF NEW HAVEN HARBOR}

The decision to dispose and cap dredged material is made through a formal, tiered decision matrix which is used as a guide for monitoring and managing disposal sites in New England (EPA/USACE 1991). Federal maintenance projects and private applicants are approved for open-water disposal when all practicable alternatives to ocean or estuarine/riverine disposal have been determined to be unavailable according to federal and state guidelines (EPA/USACE 1991).

Once these criteria are met, the dredged material is evaluated for potential environmental impacts based on laboratory analytical results. After NED completes the evaluation process, all permits are subject to review and comment by federal agencies such as EPA Region I, the National Marine Fisheries Service, and the US Fish and Wildlife Service. Approval to dredge the inner federal navigation channel of New Haven Harbor was given in October 1993. During the dredging of the inner channel, permits were granted for the following five private dredging projects within New Haven Harbor: Northeast Petroleum (two projects approved 5 and 30 November 1993), Mobil Oil and the New Haven Terminal (24 November 1993), Wyatt Incorporated (1 December 1993), and Gulf Oil (17 December 1993).

\subsection{Physical Testing of Sediment}

As part of the evaluation process, samples of dredged material are analyzed for grain size, total organic carbon, and water content. Sediments proposed for disposal may be excluded from further testing according to the tiered protocol if the majority of the material is predominantly composed of sand-sized particles or larger (EPA/USACE 1991). Sand and larger diameter particles are chemically inert and relatively free from contaminants. Therefore, they pose no environmental impact from a chemical or biological standpoint (other than a possible change in the type of community that develops on a substratum of a particular grain size).

Results of the grain size analysis for the federal navigation channel showed that the sediments contained little sand and were predominantly silt/clay (inner channel Stations AD were 93 to $97 \%$ silt/clay and outer channel Stations E-J were 77 to $99 \%$ silt/clay) (Figure 2-1; Appendix A Tables 1 and 2). The sand fractions at the New Haven Terminal ranged from 57 to $66 \%$, Mobil Oil 66 to $82 \%$, and Wyatt Incorporated from 34 to $87 \%$. Sediments dredged from Gulf Oil were almost equal in the percentage of sands and silt/clay. The majority of samples from Northeast Petroleum consisted of 87 to $93 \%$ silt/clay; only three samples contained 70 to $98 \%$ sands (Appendix A Tables 1 through 7). 


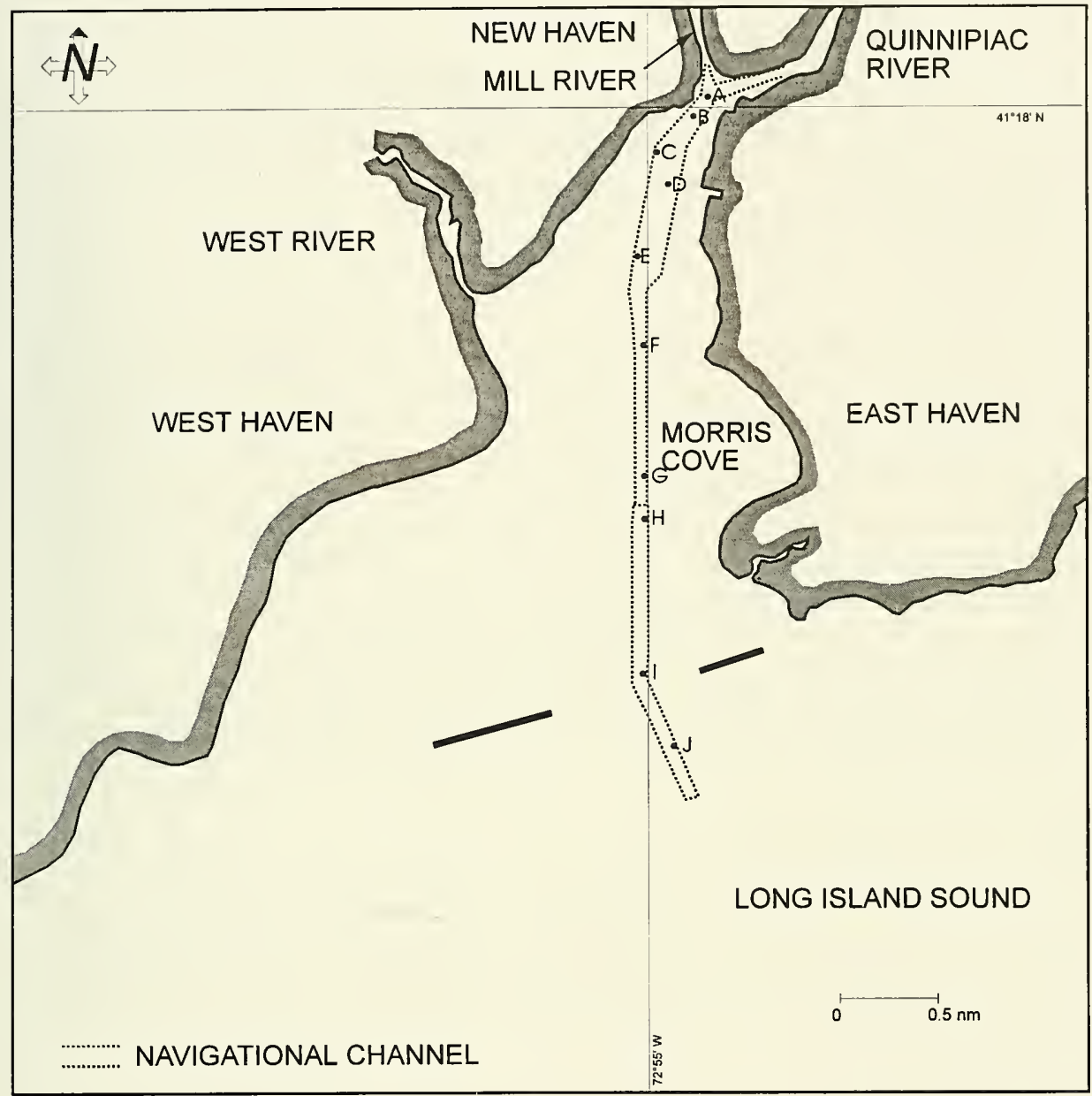

Figure 2-1. Sediment and benthic sampling locations in the federal navigation channel, New Haven Harbor. Stations A-D were located in the inner harbor (UDM), and Stations E-J were located in the outer channel (CDM). 


\subsection{Chemical Testing of Sediment}

Sediments which are not predominantly sand require bulk sediment analyses for eight metals, total polychlorinated biphenyls (PCBs), chlorinated pesticides, and polynuclear aromatic hydrocarbons (PAHs) according to EPA guidance (EPA/USACE 1991). All project areas in New Haven Harbor including the outer channel required chemical analyses.

\subsubsection{Metals}

The metals required for analysis included arsenic (As), cadmium (Cd), chromium $(\mathrm{Cr})$, copper $(\mathrm{Cu})$, mercury $(\mathrm{Hg})$, nickel $(\mathrm{Ni})$, lead $(\mathrm{Pb})$, and zinc $(\mathrm{Zn})$. Sediments from the inner federal channel contained moderate levels of all metals except $\mathrm{Hg}$ and $\mathrm{Pb}$ (present in low levels) when compared to the classification guidelines provided by the New England River Basins Commission (NERBC) (Table 2-1; Appendix A Tables 1 through 7). Zn was high in one sample (595 ppm). Low to moderate levels of $\mathrm{As}, \mathrm{Cd}, \mathrm{Cr}, \mathrm{Cu}, \mathrm{Ni}$, and $\mathrm{Zn}$ were present in sediments sampled from the outer channel with only one value of $\mathrm{Zn}$ classified as high (440 ppm). Metal concentrations were low in sediments sampled from Mobil Oil and the New Haven Terminal. Moderate levels of $\mathrm{Cr}$ (117 to $123 \mathrm{ppm}$ ), $\mathrm{Pb}$ (110 to $158 \mathrm{ppm}$ ), and $\mathrm{Zn}$ (264 to $350 \mathrm{ppm}$ ) were detected in some sediments collected from Gulf Oil; Wyatt Incorporated, Zn (213 to $265 \mathrm{ppm}$ ) and $\mathrm{Pb}$ (105 to $168 \mathrm{ppm}$ ); and Northeast Petroleum, moderate to high levels of $\mathrm{Zn}$ (235 to $919 \mathrm{ppm})$ and a moderate level of $\mathrm{Pb}(144 \mathrm{ppm})$.

\subsubsection{Organic Compounds}

Pesticides were below the detection limit for all compounds in the inner channel and outer channel sediments except for heptachlor epoxide which ranged from 0.46 to $1.94 \mathrm{ppm}$ in the inner channel and from less than the detection limit to $0.82 \mathrm{ppm}$ in the outer channel sediments. Pesticides were below the detection limit for all five terminal project areas.

Total PCBs for the inner and outer channel sediments were less than the laboratory's reported detection limit of $100 \mathrm{ppb}$. Total PCBs were detected by another laboratory in sediments collected from Mobil Oil (less than unreported detection limit to $56 \mathrm{ppb}$ ), Wyatt Incorporated (22 to $68 \mathrm{ppb}$ ), and Gulf Oil (140 to $280 \mathrm{ppb}$ ).

For the permitting process PAH values were normalized to percent organic carbon and compared to the carbon normalized PAH values for the CLIS Reference area. The concentrations of PAHs in some sediments from the inner federal channel and the five 
Table 2-1

New England River Basins Commission (NERBC)

Classification of Dredged Sediment (NERBC 1980)

\begin{tabular}{|l|c|c|c|}
\cline { 2 - 4 } \multicolumn{1}{c|}{} & Class I & Class II & Class III \\
\hline $\begin{array}{l}\text { Percent oil and grease } \\
\text { (hexane extract) }\end{array}$ & $<0.2$ & $0.2-0.75$ & $>0.75$ \\
\hline $\begin{array}{l}\text { Percent volatile solids } \\
\text { (NED method) }\end{array}$ & $<5$ & $5-10$ & $>10$ \\
\hline Percent water & $<40$ & $40-60$ & $>60$ \\
\hline Percent silt/clay & $<60$ & $60-90$ & $>90$ \\
\hline
\end{tabular}

LEVEL OF CONTAMINATION

\begin{tabular}{|l|c|c|c|}
\cline { 2 - 4 } \multicolumn{1}{c|}{} & LOW & MODERATE & HIGH \\
\hline $\mathrm{As}$ & $<10$ & $10-20$ & $>20$ \\
\hline $\mathrm{Cd}$ & $<3$ & $3-7$ & $>7$ \\
\hline $\mathrm{Cr}$ & $<100$ & $100-300$ & $>300$ \\
\hline $\mathrm{Cu}$ & $<200$ & $200-400$ & $>400$ \\
\hline $\mathrm{Hg}$ & $<0.5$ & $0.5-1.5$ & $>1.5$ \\
\hline $\mathrm{Ni}$ & $<50$ & $50-100$ & $>100$ \\
\hline $\mathrm{Pb}$ & $<100$ & $100-200$ & $>200$ \\
\hline $\mathrm{V}$ & $<75$ & $75-125$ & $>125$ \\
\hline $\mathrm{Zn}$ & $<200$ & $200-400$ & $>400$ \\
\hline
\end{tabular}


private project areas (as well as elevated levels of $\mathrm{Zn}$ in some samples collected from NE Petroleum) indicated that sediments were not suitable for open water disposal unless capped or subjected to biological testing (Appendix A Tables 1 through 7; ranges of PAHs reported here have not been normalized to TOC). The concentrations of individual PAHs in the inner channel sediments ranged from $<0.03$ to $2.39 \mathrm{ppm}$; outer channel sediments ranged from $<0.02$ to $1.07 \mathrm{ppm}$. Sediments from Wyat Incorporated had higher concentrations of individual PAHs in the Pink Tank berthing area, up to $8.70 \mathrm{ppm}$, requiring the capping of all sediments in comparison to sediments sampled from the Arco berthing area which contained concentrations of PAHs ranging from 0.08 to $3.71 \mathrm{ppm}$. Approximately $3,800 \mathrm{~m}^{3}$ from this area were considered suitable for open-water disposal. Other ranges for individual PAH compounds present above the detection limit were 1) Gulf Oil, 0.12 to $8.75 \mathrm{ppm}$; 2) Mobil Oil, 0.05 to $11.4 \mathrm{ppm}$; 3) Northeast Petroleum, 0.03 to $4.66 \mathrm{ppm}$; and 4) the New Haven Terminal, 0.09 to $6.52 \mathrm{ppm}$.

\subsection{Bioaccumulation/Bioassay Tests}

If sediment chemistry data indicate elevated levels of contaminants, bioassay and bioaccumulation testing are required. Permittees can, at this point, opt to select capping as opposed to paying for this expensive testing procedure which may indicate the need to cap anyway (EPA/USACE 1991). Whole sediment bioassays must include three species from three different phyla: a crustacean, a polychaete, and a bivalve, and bioaccumulation testing must use the survivors of the bioassay test. Data are used to determine whether or not capping need be imposed as a permit restriction (EPA/USACE 1991).

The Tier III benthic-bioaccumulation tests provide for the determination of bioavailability through 10-day exposure tests if all contaminants of concern are metals or 28-day exposure tests if any contaminants of concern are organic or organometallic compounds (EPA/USACE 1991). The decision to cap sediments from the inner harbor federal channel was based on the results of the 28-day Ampelisca bioassay which had a significant mortality compared to the reference samples.

Results of the Ampelisca bioassay showed survival in the inner harbor was $51 \%$, which was $36 \%$ lower than the reference survival of $87 \%$. This suitability determination was conservative based on the current understanding of the Ampelisca toxicity test. Survival of Nereis and Macoma in test sediments (28 days) was not significantly different from reference results based on analysis of preliminary laboratory data. Bioaccumulation in Nereis and Macoma was also not significantly different from reference samples based on analysis of preliminary data (Lawless 1991). Biological testing was not pursued for the private projects because of the availability of capping material if dredging was completed in conjunction with the federal navigation channel project. 
Additional sediment chemistry data are available through NED for the core samples and replicate sample data. Sampling and analytical work were contracted to HMM Associates, Incorporated, Concord, Massachusetts. Methods used for grain size, TOC, and metals were not provided; however, PAHs were analyzed by EPA Method 8270, and chlorinated pesticides and total PCBs by EPA Method 8080 . Bioassay studies were conducted by SP, Incorporated, Salem, MA. Skinners and Sherman, Waltham, MA, conducted the bioaccumulation tissue analysis. Cadmium, copper, and zinc were analyzed in the tissue following EPA Methods 3051, 6010, and 7131. Pesticides were analyzed by Method 8080 and PAHs by Method 8270.

\subsection{Disposal and Capping Operations}

The Great Lakes Dredge and Dock Company conducted the dredging operations in New Haven Harbor with Clamshell Dredge 54. Disposal and capping at CLIS were achieved with the use of Great Lakes' $4000 \mathrm{yd}^{3}$ disposal barges 32 and 33 and Towing Vessels (T/V) Arthur F. Zeman, Jr. and Delmur C. Lynn. Additional disposal work was performed by Gateway Towing, Inc. T/V Outrageous and United Towing, Inc. T/V Terror during the New Haven Capping Project.

\subsubsection{Disposal of UDM}

Of the total volume of UDM $\left(590,226 \mathrm{~m}^{3}\right)$, approximately $500,369 \mathrm{~m}^{3}$ was dredged from the inner federal navigation channel. During the month of October 1993, approximately $460,083 \mathrm{~m}^{3}$ from the inner channel was deposited at the NHAV buoy (Appendix B Table 1). The remaining $40,286 \mathrm{~m}^{3}$ were deposited at disposal point I, located southwest of the buoy $\left(41^{\circ} 09.000^{\prime} \mathrm{N}\right.$ and $72^{\circ} 53.525^{\prime} \mathrm{W}$ ) (Figure 2-2). UDM from the private dredging projects totaling $89,857 \mathrm{~m}^{3}$ was also deposited at disposal point I from 3 December 1993 to 8 January 1994 (Appendix B Table 1). This allowed capping to begin on the northern side of the mound while contaminated sediments were disposed on the southern side of the mound.

\subsubsection{Capping Operations}

In addition to the use of the DAMOS capping model (which was not designed for large volume dredged material projects such as the New Haven capping project because it has a tendency to create unrealistically high central mound heights) capping operations were designed using a simple geometric analysis of volume and potential cap thickness. It was predicted that the dredged material would be placed in a berm-shaped mound approximately $5 \mathrm{~m}$ high, $250 \mathrm{~m}$ wide, and $608 \mathrm{~m}$ long including the thin flanks. The total areas to be covered by the cap material would need to extend $50 \mathrm{~m}$ beyond these 


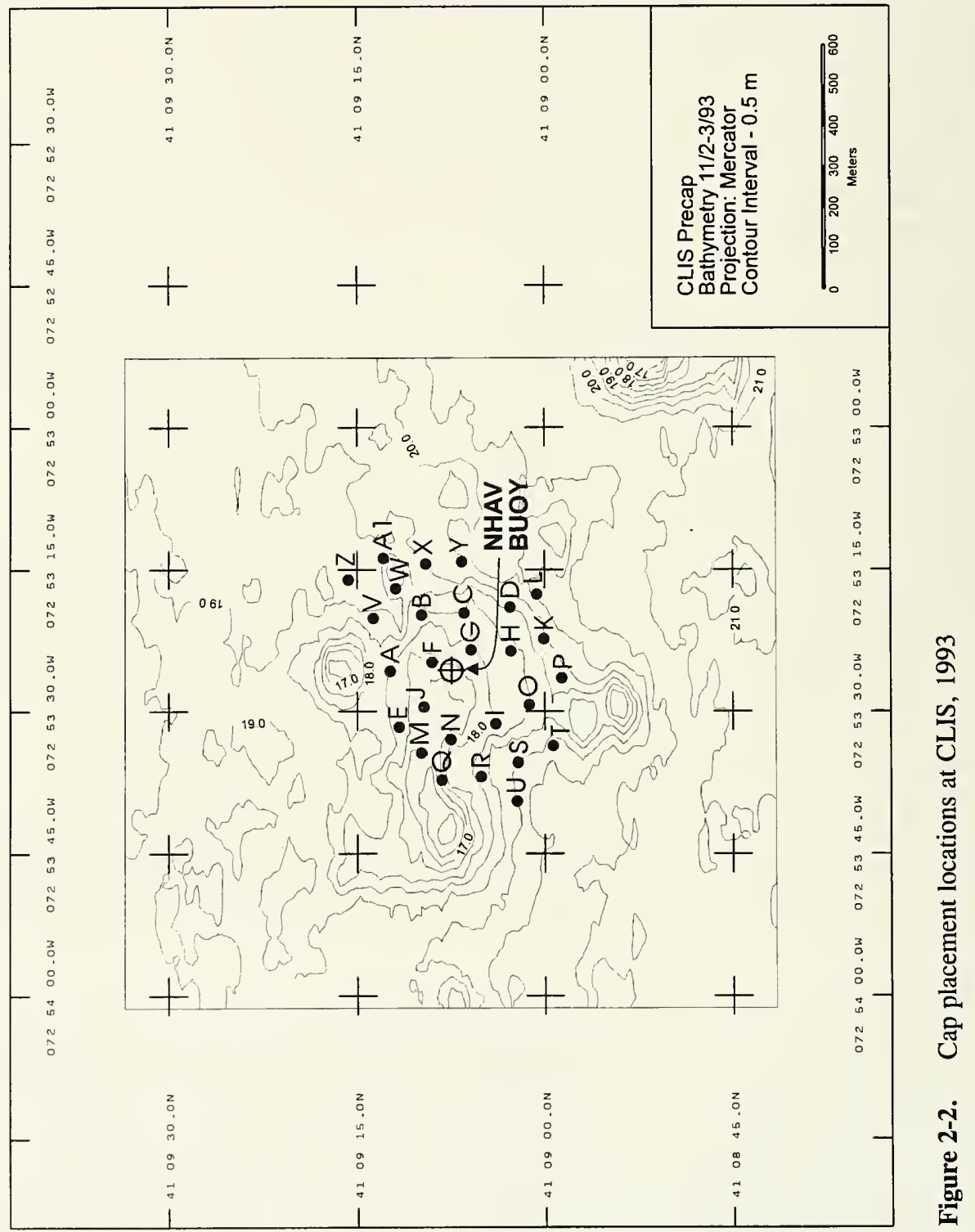


dimensions with a designated cap thickness of $50 \mathrm{~cm}$ to $1 \mathrm{~m}$. These calculations were based on estimated amounts of $539,800 \mathrm{~m}^{3}$ of contaminated dredged material and $397,000 \mathrm{~m}^{3}$ of cap material. Prior experience in the construction of capped sediment mounds at CLIS (STNH-N, STNH-S, MQR, CS-1, CS-2, and NORWALK) was also incorporated into the NHAV 93 mound capping design (SAIC 1995).

CDM dredged from the outer New Haven Harbor provided the bulk of the cap material, 505,848 $\mathrm{m}^{3}$. Additional $\mathrm{CDM}$ was also obtained from sediments dredged from NE Petroleum, Lex Atlantic/Gateway, and Wyatt Incorporated terminals. This volume amounted to $63,439 \mathrm{~m}^{3}$. The total volume of available cap material was $569,287 \mathrm{~m}^{3}$.

Capping of the UDM deposit took place in several stages using a series of cap placement points (Figure 2-2; Appendix B Table 2) designed for complete coverage of the UDM mound. Prior to the precap survey, approximately $76,000 \mathrm{~m}^{3}$ of CDM was deposited near points A, F, and J (Figure 2-2). The directed cap disposal began with depositing outer channel sediments at disposal points A-E on a rotating basis ( 3 November 1993). Additional UDM from the federal channel and private terminals was deposited at point I during this stage.

The second stage of capping began on 18 November 1993 when disposal was directed to points $F, G, H, J, K$, and $L$, again on a rotating basis. UDM continued to be disposed at point I. Beginning on 10 December 1993, capping operations were directed to points $\mathrm{G}, \mathrm{K}, \mathrm{L}, \mathrm{V}, \mathrm{W}, \mathrm{X}, \mathrm{Y}, \mathrm{Z}$, and Al. Disposal at eight of the nine points (excluding $\mathrm{G}$ ) was completed on a rotating basis for cap sediments from the federal project and Northeast Petroleum. Point $G$ was used for placement of Lex Atlantic/Gateway sediments. Location I was maintained for further disposal of UDM. A fourth revision in distribution of the cap material occurred on 22 December 1993. This stage began with disposal of cap material at and around point I (five trips) and the NHAV buoy (five trips). Additional cap material was then placed at points $\mathrm{N}, \mathrm{R}, \mathrm{S}$, and $\mathrm{O}$ (three trips each). Once these trips were completed, capping was carried out on a rotating basis at the NHAV buoy and points G, I, $\mathrm{M}, \mathrm{N}, \mathrm{O}, \mathrm{P}, \mathrm{Q}, \mathrm{R}, \mathrm{S}, \mathrm{T}$, and $\mathrm{U}$. This was intended to cap the most recently disposed contaminated material. 


\subsection{METHODS}

SAIC conducted five monitoring surveys from September 1993 to March 1994: 1) baseline, 2) interim disposal, 3) precap, 4) interim cap, and 5) postcap (Figure 1-2) (Table 1-2). In addition to the comprehensive dataset generated by the strategic repetition of SAIC's survey activity, Ocean Surveys Incorporated conducted an interim cap survey in January 1994 to fulfill a contract with the marine terminals involved in the dredging project. Results of this survey are reported in Section 4.1.4.

The SAIC Integrated Navigation and Data Acquisition System (INDAS) provided the precision navigation required for all SAIC field operations. This system uses a Hewlett-Packard $9920^{\circledR}$ series computer to collect position, depth, and time data for later analysis, as well as provide real-time navigation. A Del Norte Microwave Trisponder ${ }^{\circledR}$ System provided positioning to an accuracy of $\pm 3 \mathrm{~m}$. Shore stations were established in Connecticut at known benchmarks at Stratford Point $\left(41^{\circ} 09.112^{\prime} \mathrm{N}, 73^{\circ} 06.227^{\prime} \mathrm{W}\right)$ and Lighthouse Point $\left(41^{\circ} 14.931^{\prime} \mathrm{N}, 72^{\circ} 54.255^{\prime} \mathrm{W}\right)$. A detailed description of the navigation system and its operation can be found in SAIC Report No. 290 (Murray and Selvitelli 1993).

\subsection{Precision Bathymetric Surveys}

The five precision bathymetric surveys that documented the stages of mound development were all centered at $41^{\circ} 09.125^{\prime} \mathrm{N}, 72^{\circ} 53.450^{\prime} \mathrm{W}$, and conducted over a $1600 \mathrm{~m} \times 1600 \mathrm{~m}$ area. The surveys were oriented east to west using $25 \mathrm{~m}$ lane spacing and requiring 65 lanes to fully cover the $2.56 \mathrm{~km}^{2}$ area. An ODOM DF3200 Echotrac ${ }^{\circledR}$ Survey Fathometer with a narrow-beam $208 \mathrm{kHz}$ transducer measured individual depths to a resolution of $3.0 \mathrm{~cm}(0.1$ feet) as described in SAIC Report No. 290 (Murray and Selvitelli 1993). Depth values transmitted to the computer were adjusted for transducer depth. The acoustic records reliably detect changes in depth on the order of $20 \mathrm{~cm}$ due to the accumulation of errors introduced by the positioning system, tidal corrections, the calibration of the fathometer (speed of sound through the water column), the slope of the bottom, and the vertical motion of the vessel.

During each bathymetric survey, tidal variations at the disposal site were recorded using a Seabird Instruments, Inc. SBE 26-03 Sea Gauge wave and tide recorder. Pressure readings were collected at 6 minute intervals for the duration of the survey. After conversion to water depths, the readings provided a constant record of tidal variations over the survey area. The observed tidal data were later used to correct the bathymetric survey data. 
Sound velocity measurements were obtained before and after the bathymetric survey using a Seabird Instruments, Inc. SEACAT SBE 19-01 Conductivity, Temperature, and Depth probe (CTD). The CTD was lowered over the side and allowed to equilibrate in ambient seawater for one to two minutes before initiating the cast. The CTD provided a profile of temperature, depth, salinity, and sound velocity in the water column. A mean sound velocity was then calculated and applied to the bathymetric data.

The data collected during each of the five bathymetric surveys were analyzed using SAIC's Hydrographic Data Analysis System v. 1.03 (HDAS). During analysis, raw bathymetric data were corrected for sound velocity and standardized to Mean Tidal Level. The corrected bathymetric data were then used to construct depth models of the surveyed area. Depth difference calculations were performed using the HDAS volume differencing routines. In order to assist NED in achieving its goal, SAIC supplied detailed contour and depth difference plots of the survey area 48 hours after each survey in order to modify the disposal or capping activity to ensure proper containment and coverage. A detailed discussion of the bathymetric analysis technique is given in SAIC Report No. 290 (Murray and Selvitelli 1993).

\subsection{REMOTS ${ }^{\circledast}$ Sediment-Profile Surveys}

Actual REMOTS ${ }^{\circledR}$ station locations (latitude and longitude) occupied during the surveys are provided in Appendix C along with analytical results. REMOTS ${ }^{\circledR}$ sedimentprofile surveys were conducted prior to disposal to assess baseline conditions and after UDM disposal (precap survey) (Figure 1-2). Designed to obtain in situ profile images of the top $20 \mathrm{~cm}$ of the sediment, the REMOTS ${ }^{\circledR}$ sediment-profile camera has been used to detect and map the distribution of thin $(0.1-20 \mathrm{~cm})$ dredged material layers, and document seafloor processes and organism-sediment relationships as they occur naturally on the seafloor and on the disposal site (Rhoads and Germano 1990). Specific measurement/ observational techniques for determining REMOTS $^{\circledR}$ parameters include sediment grain size major mode and range, prism penetration depth, surface boundary roughness, presence/absence and size of mud clasts, apparent redox potential discontinuity (RPD) depth, apparent presence/absence of sedimentary methane, infaunal successional stage, and calculation of the REMOTS ${ }^{\circledR}$ Organism-Sediment Index (OSI).

\subsubsection{Baseline Survey}

During the September 1993 baseline survey, REMOTS ${ }^{\circledR}$ sediment-profile photographs were obtained in triplicate from 30 stations surrounding the NHAV buoy (Figure 3-1; Appendix C Table 1). A series of six-station transects were occupied, over five surrounding sediment mounds (CLIS 87-88 complex, CLIS 89, CLIS 90, NORWALK, 


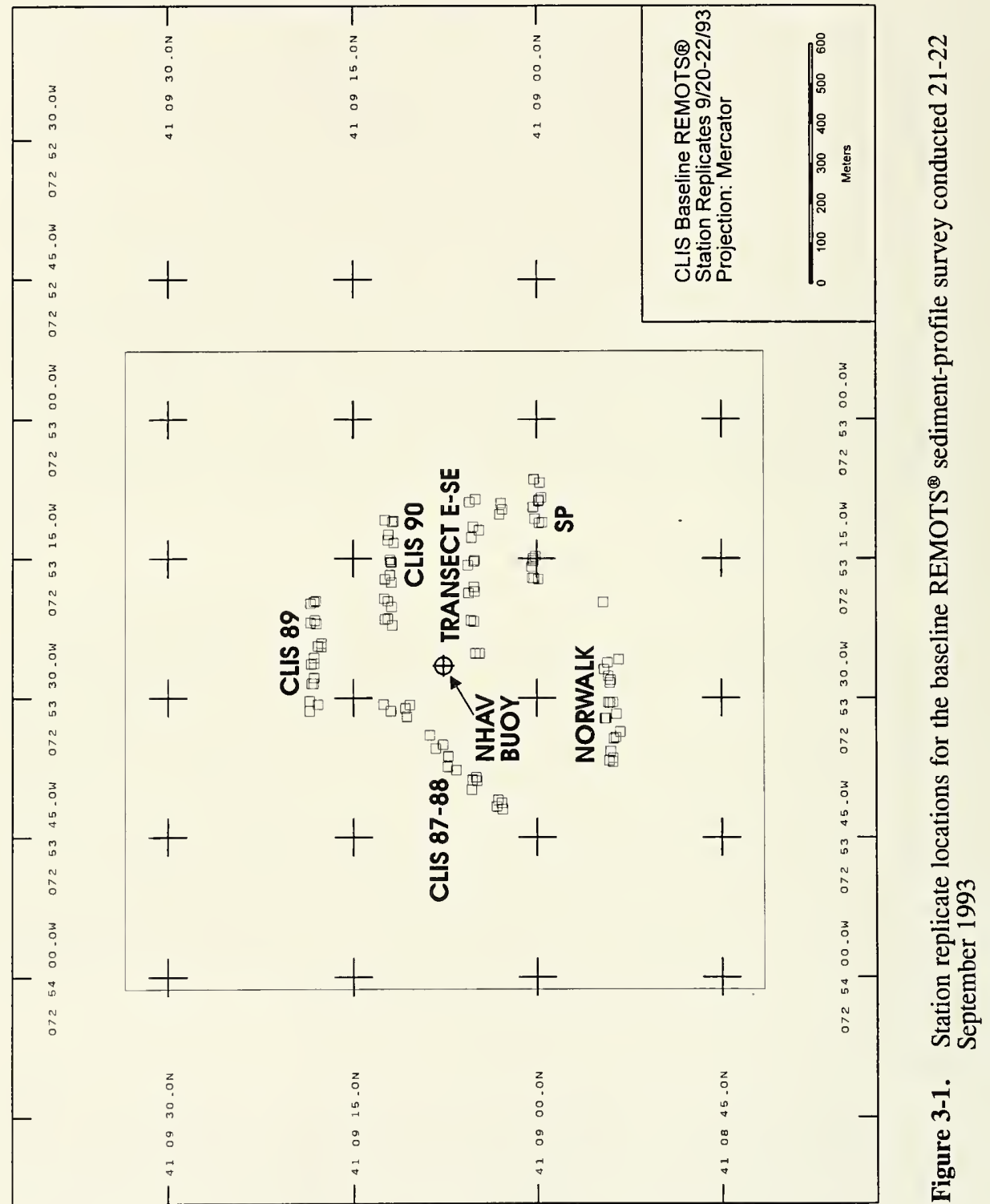


and SP) and along the east-southeast valley area to determine recolonization status and relative shear strength of the sediments (Figure 3-2; Appendix C Table 2).

\subsubsection{Precap Survey}

SAIC conducted a second REMOTS ${ }^{\circledR}$ survey on 3-4 November 1993 following the completion of the inner harbor dredging. Transects were oriented in the eight major compass directions (N, NE, E, SE, S, SW, W, NW) to delineate the apron of the disposal mound for capping. The survey was conducted from the center of the mound $\left(41^{\circ} 09.100^{\prime} \mathrm{N}, 72^{\circ} 53.442^{\prime} \mathrm{W}\right)$ as determined by the interim disposal survey. Each transect began $325 \mathrm{~m}$ from the center and consisted of four stations spaced $75 \mathrm{~m}$ apart extending a total of $550 \mathrm{~m}$ from the center. Three replicate samples were taken at each station. The presence and/or absence of dredged material was determined for each REMOTS $^{\circledR}$ sediment-profile photograph (Figure 3-2).

In addition to the eight directional transects, two other stations in the southwest quadrant were also sampled, $400 \mathrm{~m} \mathrm{SSW}$ and $400 \mathrm{~m}$ WSW, during the precap survey (Appendix C Table 2). The southwest quadrant may be selected as a site for future disposal operations, and information from these stations was used to provide greater detail on the distribution of dredged material and status of the benthic community. A nine-station cross-shaped grid was conducted over the historic FVP mound in the northeast corner of the disposal site. The REMOTS images were used to determine whether excess cap material should also be directed to the FVP mound (Appendix C Table 3).

\subsection{Geotechnical Cores/Surface Grabs}

Geotechnical cores were obtained in a joint effort between SAIC and the University of Rhode Island (URI) using the PVC version of the Marine Geotechnical Laboratory (MGL) Large-diameter Gravity Corer (LGC) (Appendix D Table 1, and Figures 1 through 3) (Silva et al. 1994a). The core barrel consisted of a $3 \mathrm{~m} \mathrm{(10} \mathrm{ft)} \mathrm{section} \mathrm{of} \mathrm{Schedule} 40$ PVC with a $10.2 \mathrm{~cm}$ (4.0 in) inside diameter. The PVC core barrel included a nose cone and core catcher at the bottom. Basement sediments were cored during the baseline and precap surveys to establish geotechnical characteristics before loading by any additional layers of material. During each interim survey (i.e., disposal and capping) sediment grabs were collected from the vicinity of the NHAV buoy and the center of the disposal mound to characterize the surface sediments (Figure 1-2; Appendix D Table 2).

Basement material, UDM, and CDM were cored immediately following completion of the CAD mound to establish the initial geotechnical characteristics of the completed mound (Figure 1-2). These data will be used as a reference for future geotechnical 


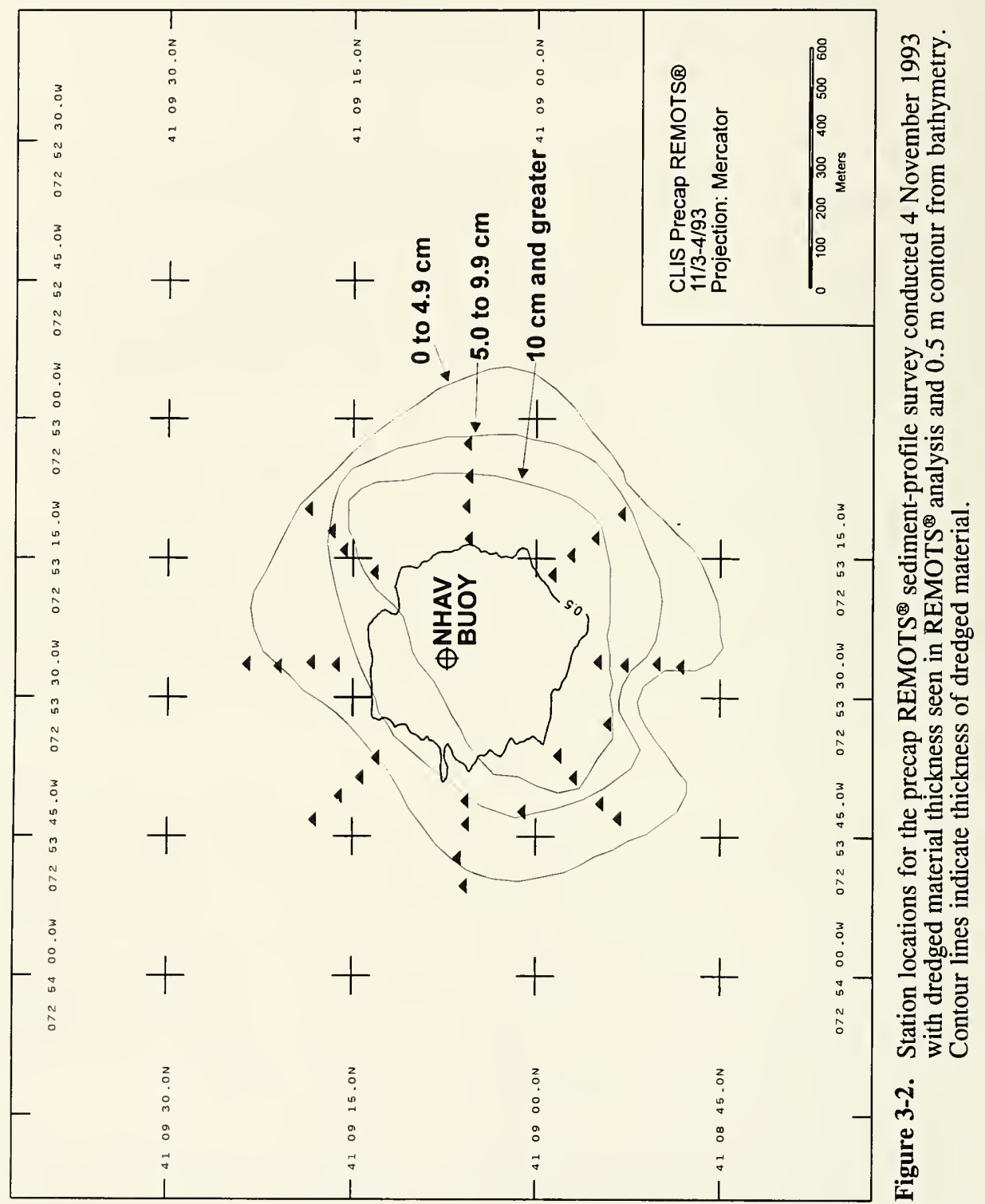


and bathymetric surveys over the NHAV 93 mound and to carry out numerical computations of settlement and volume changes.

Results of URI's analysis of the sediment cores and surface grabs have been submitted in a separate report (Silva et al. 1994b). Twenty good quality cores with lengths from $69 \mathrm{~cm}$ to $302 \mathrm{~cm}$ were recovered during the baseline, precap, and postcap surveys using the LGC system (Appendix D). Before splitting the cores (core liners), a MultiSensor Core Logger (MSCL) was used to obtain profiles of sediment bulk density. Visual descriptions (and photographs) were recorded and subsamples extracted for analysis of the physical properties (grain size, water content, Atterberg limits, and specific gravity). Consolidation behavior was measured through analysis (void ratio versus effective stress, compression index, and consolidation stress) and permeability data (direct and indirect measurements). 


\subsection{RESULTS}

\subsection{Repetitive Bathymetric Surveys}

CLIS is located in a depositional area of Long Island Sound, characterized by mild bottom current regimes and subject to shallow, wind-driven waves. Since 1984, the DAMOS site management strategy at CLIS has been to create a ring of disposal mounds for the deposition of large volumes of dredged material. The New Haven Capping Project marks the first instance that an artificial containment measure was designed and utilized for the deposition of dredged material. The entire CAD mound development process was observed, scrutinized, and documented by SAIC in support of the DAMOS Program. Results of the precision bathymetry and depth difference analyses for the five surveys conducted at CLIS between September 1993 and March 1994 are presented below including 1) baseline (predisposal), 2) interim disposal, 3) precap, 4) interim cap, and 5) postcap.

\subsubsection{Baseline Survey (19-20 September 1993)}

Results of the baseline bathymetry indicate, with the exception of shallower water depths over the mounds, water depths in the area range from $19 \mathrm{~m}$ in the northern half of the surveyed area to $21 \mathrm{~m}$ in the southern portion (Figure 1-1). Water depths over the mound centers were as follows: CLIS-87 and CLIS-88 $16 \mathrm{~m}$, CLIS-89 $17 \mathrm{~m}$, CLIS-90 $19 \mathrm{~m}$, CLIS-91 $19 \mathrm{~m}$, NORWALK $18.5 \mathrm{~m}$, and SP $19.5 \mathrm{~m}$. The historic NHAV-74 mound is visible in the southeast corner of the bathymetric chart with a minimum depth of $17.0 \mathrm{~m}$ before extending beyond the survey area.

\subsubsection{Interim Disposal Survey (23-25 October 1993)}

The interim disposal survey was completed when the federal inner harbor dredging was $50 \%$ complete. Development of the mound is readily apparent in the bathymetric analysis of the interim survey (Figure 4-1) when compared to the baseline survey (Figure 1-1). The water depth at the center of the NHAV 93 UDM mound was $17.0 \mathrm{~m}$. The depth difference comparison between the baseline and interim disposal surveys (Figure 4-2) showed a mound approximately 400 to $450 \mathrm{~m}$ in diameter and $3 \mathrm{~m}$ in height. The total volume of the mound based on successive bathymetric surveys was $238,000 \mathrm{~m}^{3}$ (Table 4$1)$. 







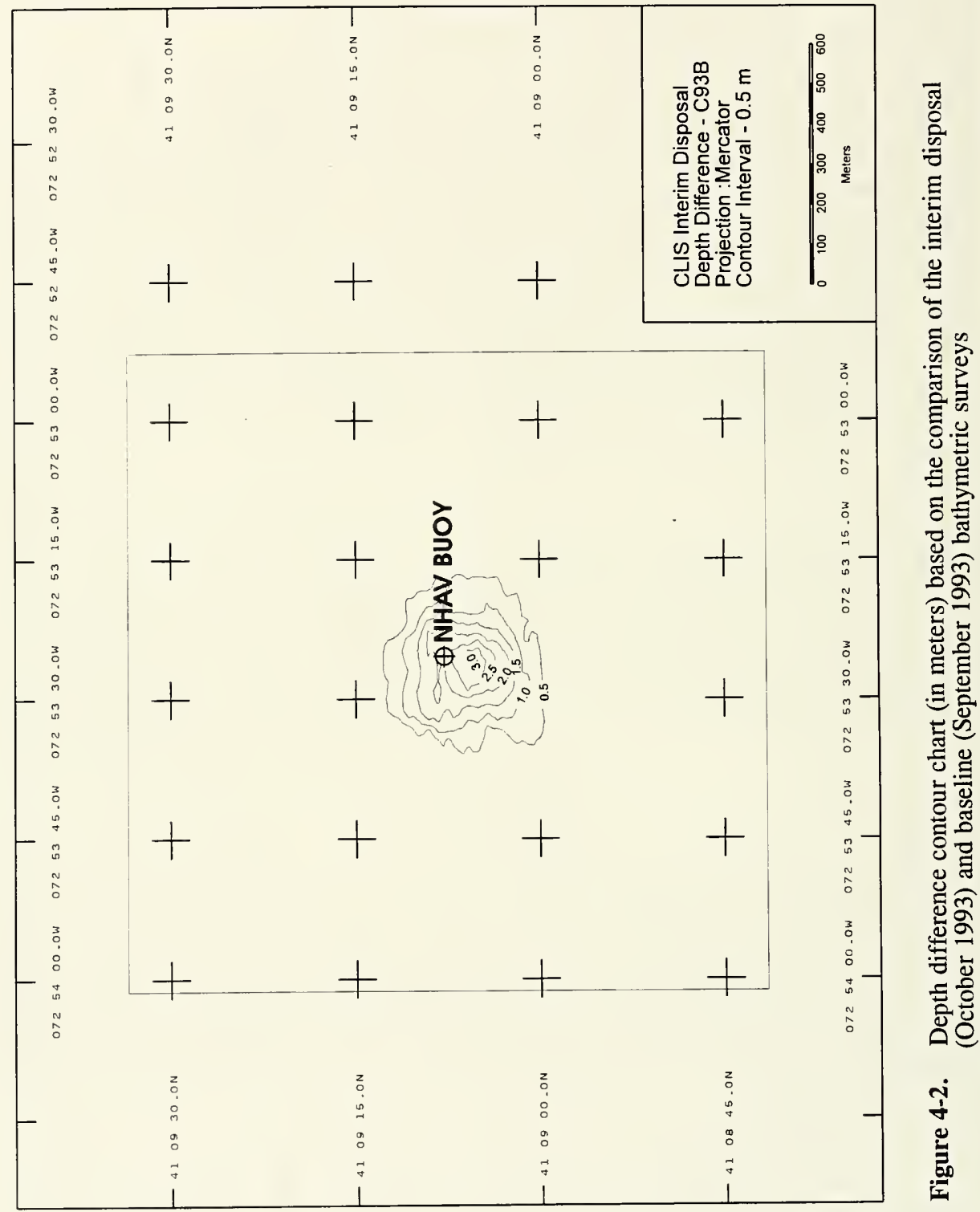




\section{Table 4-1}

Summary of Volume Difference Calculations for the New Haven Capping Project, September 1993 to March 1994

\begin{tabular}{|lr|}
\hline & $\mathbf{m}^{\mathbf{3}}$ \\
\hline Baseline/Interim Disposal & 238,000 \\
Interim Disposal/Precap & $\mathbf{7 4 , 0 0 0}$ \\
\cline { 2 - 2 } TOTAL DREDGED MATERIAL & $\mathbf{3 1 2 , 0 0 0}$ \\
\hline Precap/Interim Cap & 124,000 \\
Interim Cap/Postcap & 278,000 \\
\hline \multicolumn{1}{|c}{ TOTAL CAP } & $\mathbf{4 0 2 , 0 0 0}$ \\
\hline TOTAL VOLUME & $\mathbf{7 1 4 , 0 0 0}$ \\
\hline
\end{tabular}

\subsubsection{Precap Survey (2-3 November 1993)}

This survey measured the NHAV 93 mound following the completion of the federal inner harbor dredging and UDM deposition, as well as the disposal of 76,000 $\mathrm{m}^{3}$ of cap material at the northwest capping locations. Disposal of UDM from the private dredging operations continued over the southwestern flank of the disposal mound. (Figure 2-2, point I). The analysis of bathymetric data from the precap survey (Figure 4-3) indicated a loss in mound height $(0.5 \mathrm{~m})$ from the interim disposal survey (Figure 4-1). An interesting result of the bathymetric comparison is evidence of a large amount of consolidation or slumping of the dredged material. The depth difference contours between the interim disposal and precap survey (Figure 4-4) show the loss at the mound peak due to structural failure of the apex. The profile plot comparing survey lane 35 from the interim and the precap survey (Figure 4-5) is included to show the evidence of slumping of the mound peak and the movement of material towards the northeast. Results of the depth difference between the baseline and precap operations (Figure 4-6) show the size of the mound to be approximately $510 \mathrm{~m}$ in diameter and $2.5 \mathrm{~m}$ in height. The calculated total volume of the mound based on the baseline and precap bathymetric surveys is $312,000 \mathrm{~m}^{3}$. The volume shown by the depth difference model between the interim disposal survey and the precap survey is $74,000 \mathrm{~m}^{3}$. 


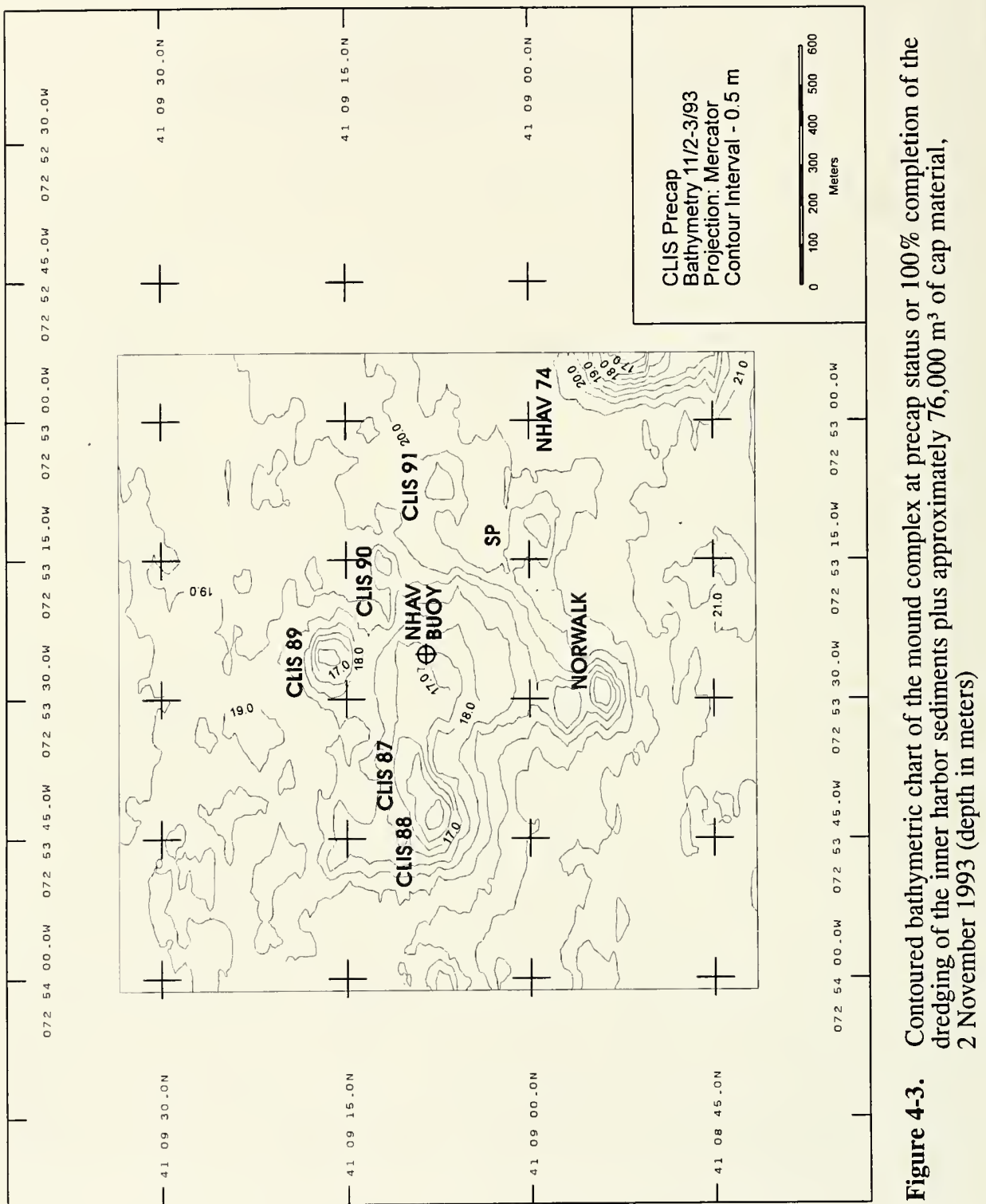




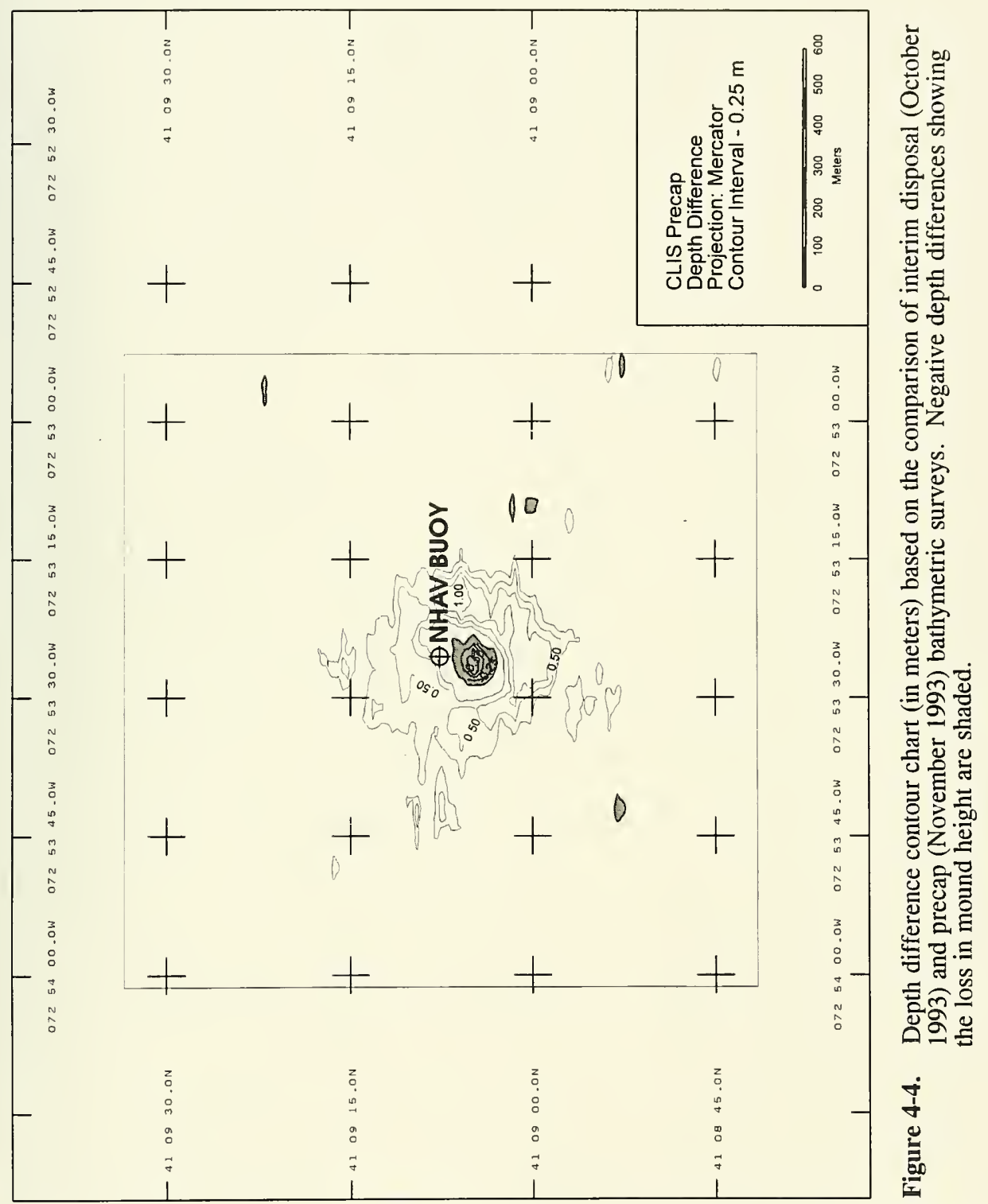



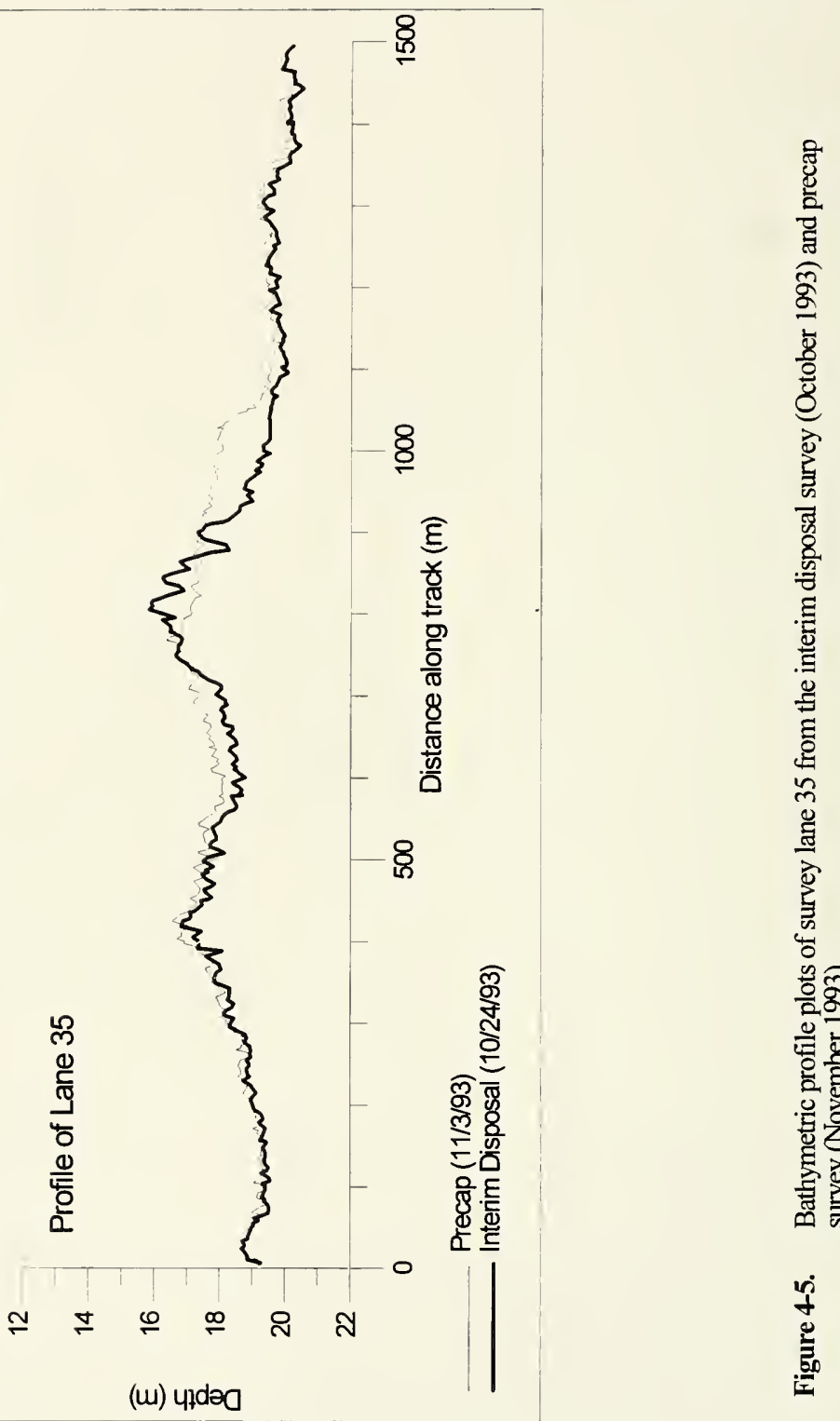


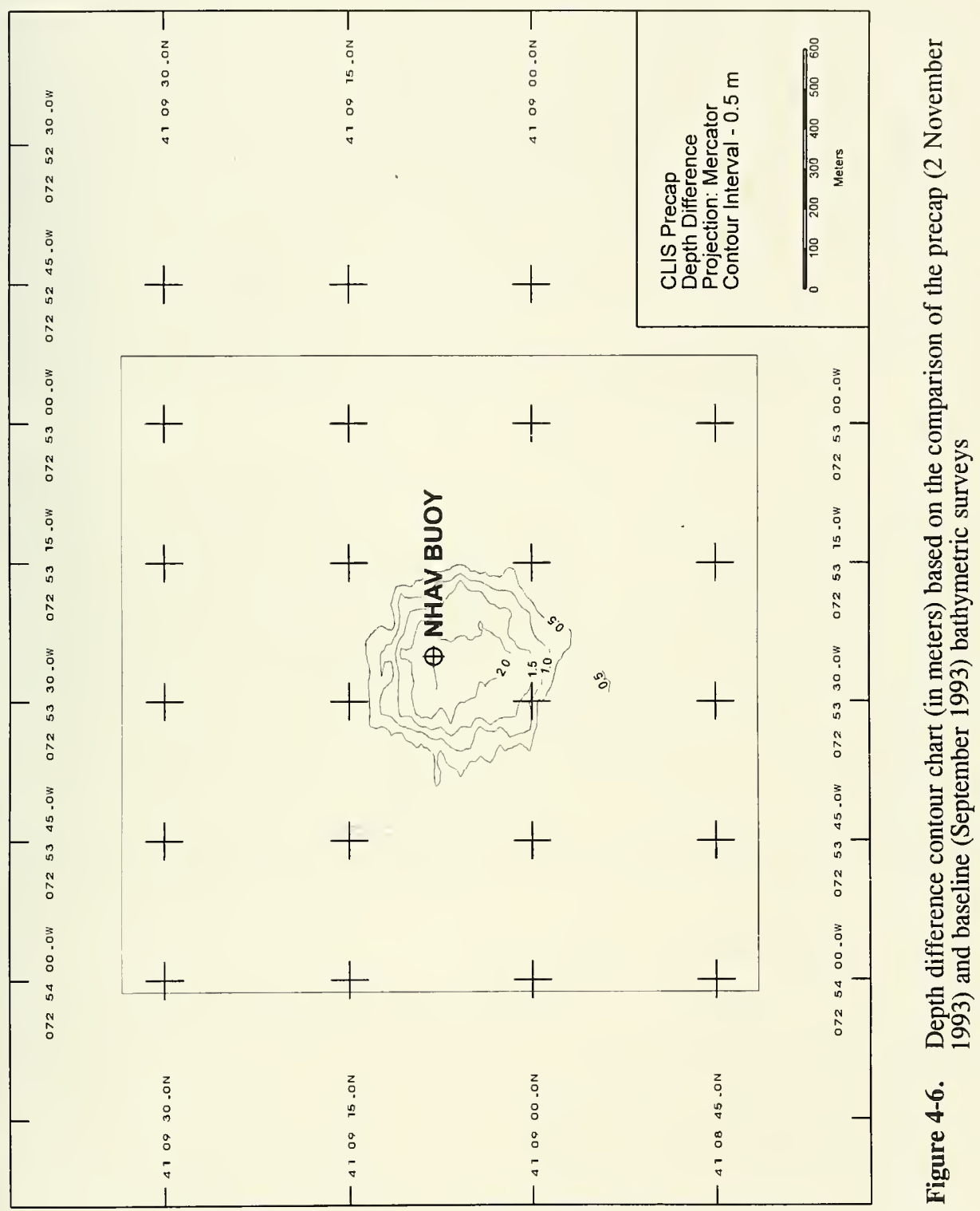




\subsubsection{Interim Cap Surveys (23-24 November 1993 and 12-13 January 1994)}

Two interim cap bathymetric surveys were conducted, one by SAIC in late November (Figure 4-7) when the federal capping operations were $50 \%$ complete and another by Ocean Surveys Incorporated on 12-13 January 1994 (Figure 4-8) following the completion of the dredging of contaminated sediment from the private terminals. Results of the depth difference comparing the 2-3 November precap survey to the 23-24 November interim cap survey (Figure 4-9) showed that the volume added to the mound was $124,000 \mathrm{~m}^{3}$ to the east and southeast of the buoy. Most of the capping activity following the interim cap survey was concentrated in the southwestern portion of the mound where the UDM originating from the private terminals was deposited. The height of the mound was $2.5 \mathrm{~m}$, and the diameter of the mound was approximately $550 \mathrm{~m}$. The depth difference comparing the November interim cap survey to the September baseline survey showed the total volume of the mound to be $435,000 \mathrm{~m}^{3}$.

In comparing the data from the Ocean Surveys Incorporated survey (Figure 4-8) to the SAIC baseline survey (Figure 1-1) there was an average overall discrepancy of $0.92 \mathrm{~m}$. This difference was the result of comparing datasets corrected to dissimilar vertical datums used for tidal corrections. SAIC data is referenced to observed Mean Tide Level (MTL) over the survey area, while Ocean Surveys Incorporated used tidal corrections based on Mean Lower Low Water (MLLW) predictions. After correcting the Ocean Surveys Incorporated data to previous SAIC surveys, two depth difference plots were generated. The first plot shows the thickness of material added since the baseline survey (Figure 410). This represents a total mound volume of about $593,000 \mathrm{~m}^{3}$. The second depth difference shows the material added between the January and precap (November 2-3) surveys (Figure 4-11). The volume from this comparison, 281,000 $\mathrm{m}^{3}$, includes all of the privately dredged contaminated sediments and some of the federal capping sediments. This plot illustrates that the deposition of dredged material during this period was mostly over the southeast flank of the NHAV 93 mound in accordance with the direction from NED.

\subsubsection{Postcap Survey (13-14 March 1994)}

Comparison of the postcap (Figure 4-12) and baseline (Figure 1-1) bathymetric surveys shows the formation of a well-developed mound centered $125 \mathrm{~m}$ to the south of the NHAV buoy. The water depth at the center of the mound is $17.5 \mathrm{~m}$. The depth difference comparison of the postcap survey versus the baseline survey (Figure 4-13) shows the height of the mound to be $2.5 \mathrm{~m}$ and the mound diameter to be $600-800 \mathrm{~m}$. The final volume of the capped NHAV mound based on that comparison is approximately $714,000 \mathrm{~m}^{3}$. Differencing the postcap survey to the precap survey (Figure 4-14) shows the total volume of cap material and privately dredged sediments to be approximately 


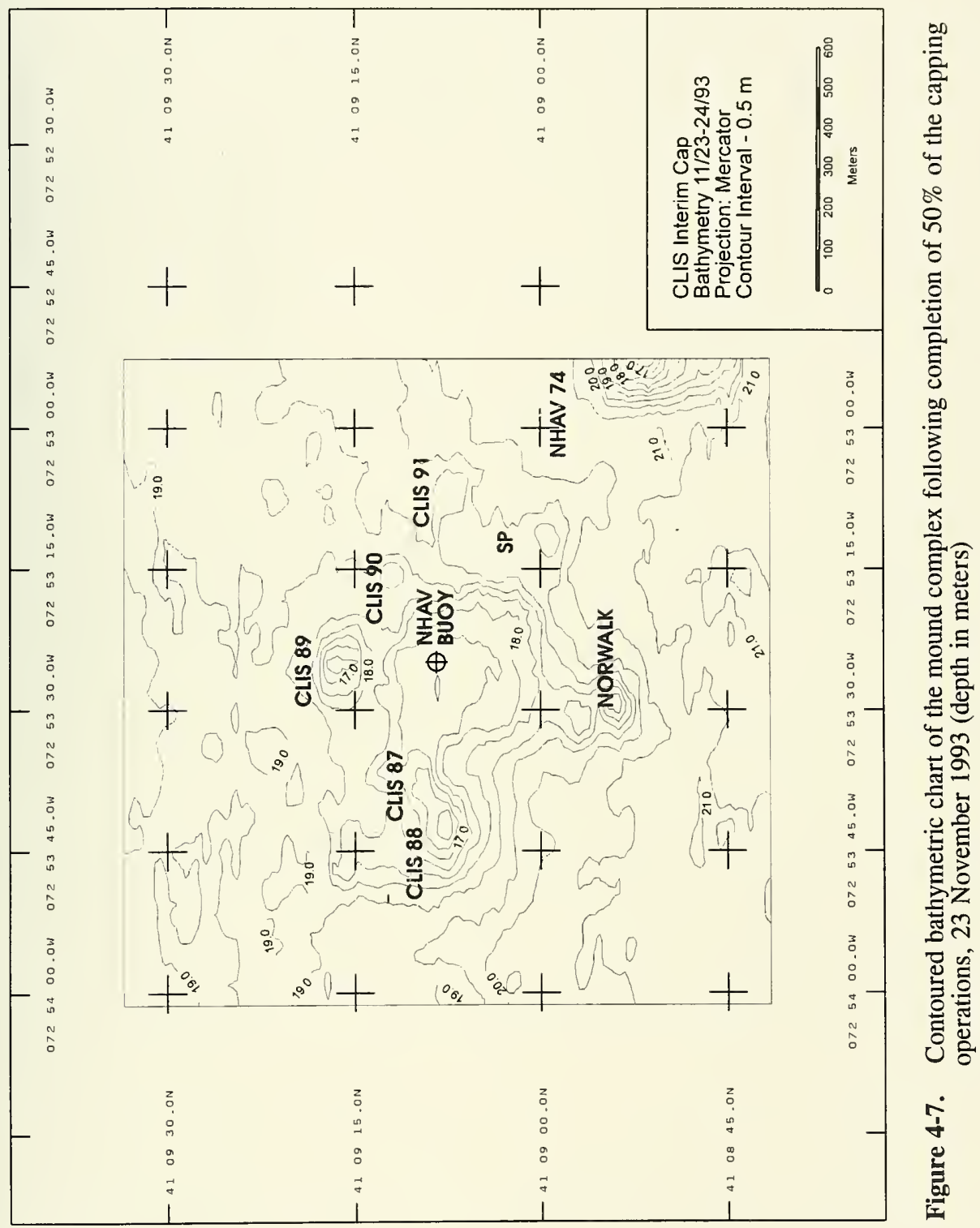




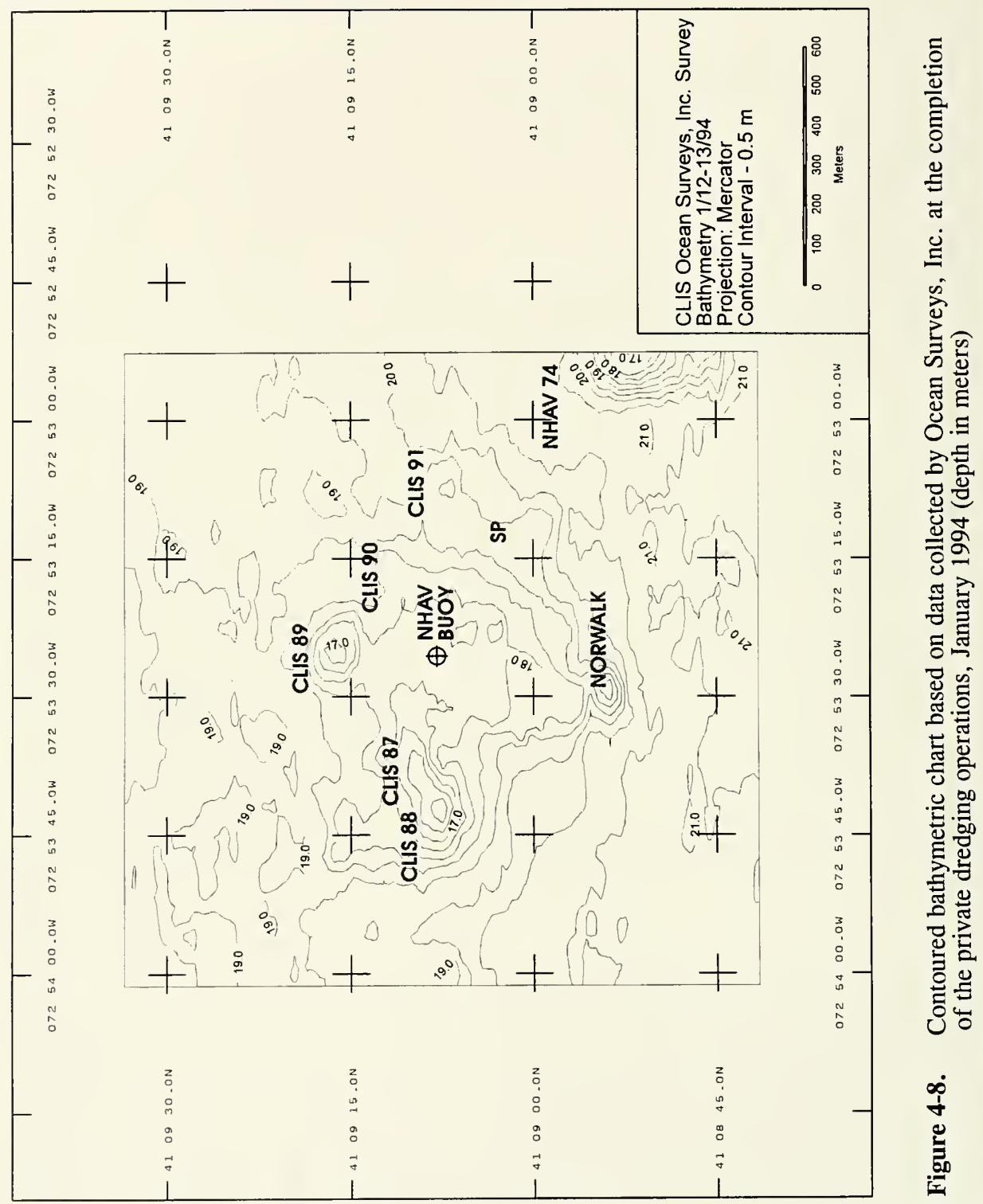




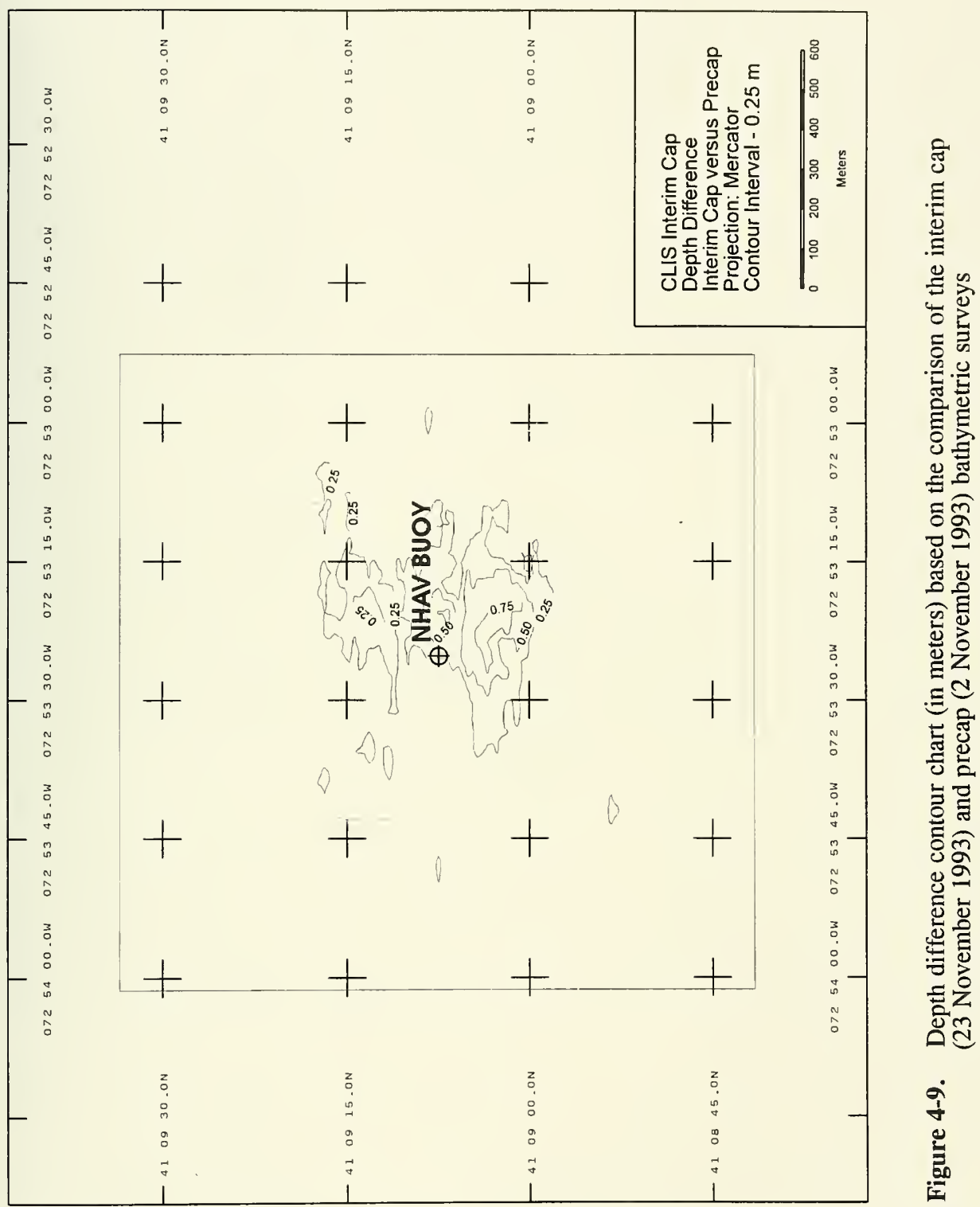




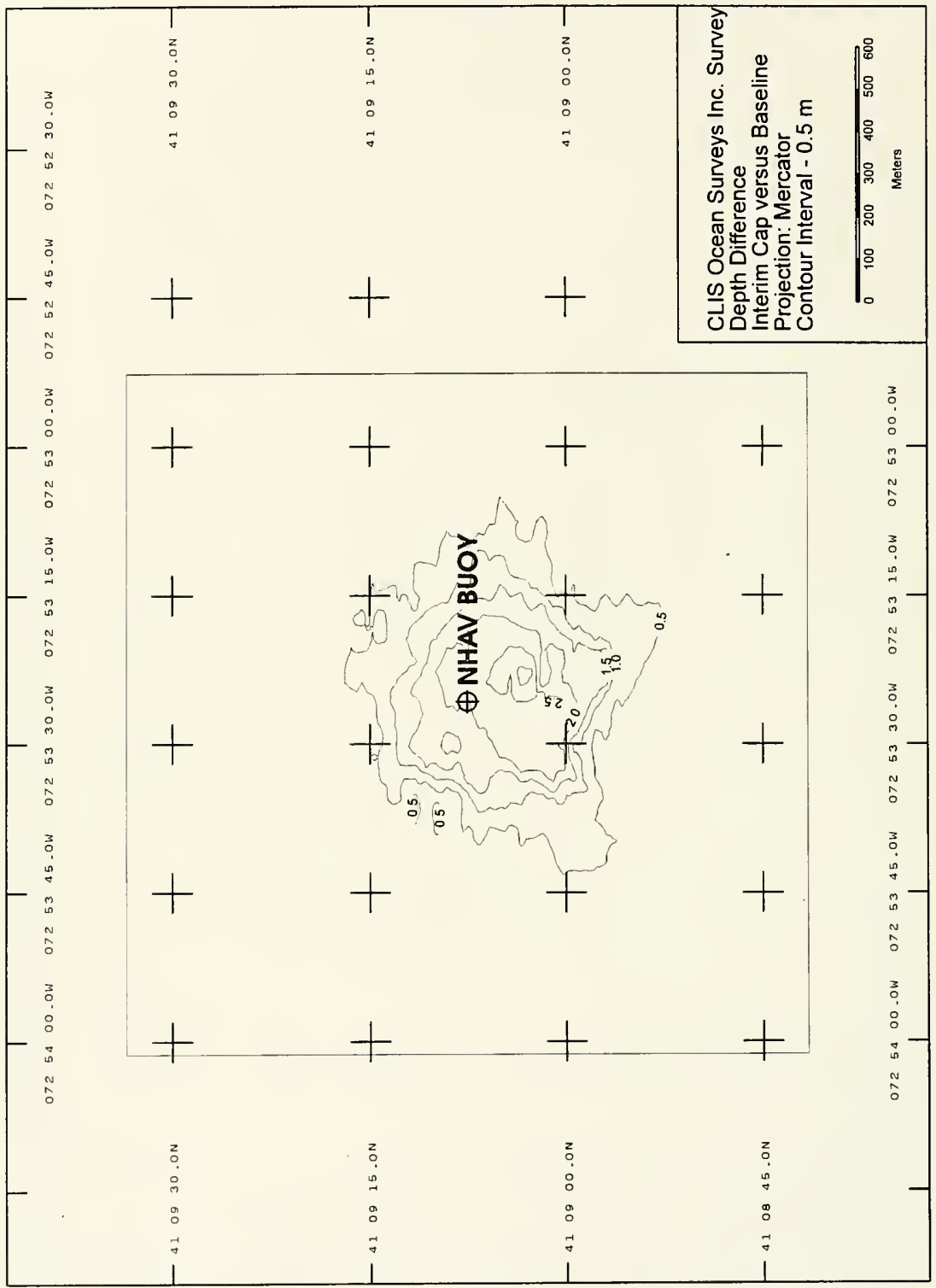

g

i

ज ฝ

콜를

通

О.

岂

4

동

ซึิ

트

ชิ เ

퐁

등 ⿺辶

च

苂.

कृष

Ð

约

E匹

흘 을

द्ञ

ปั

킁으

롱

纪

車

$=$

อั.

完 


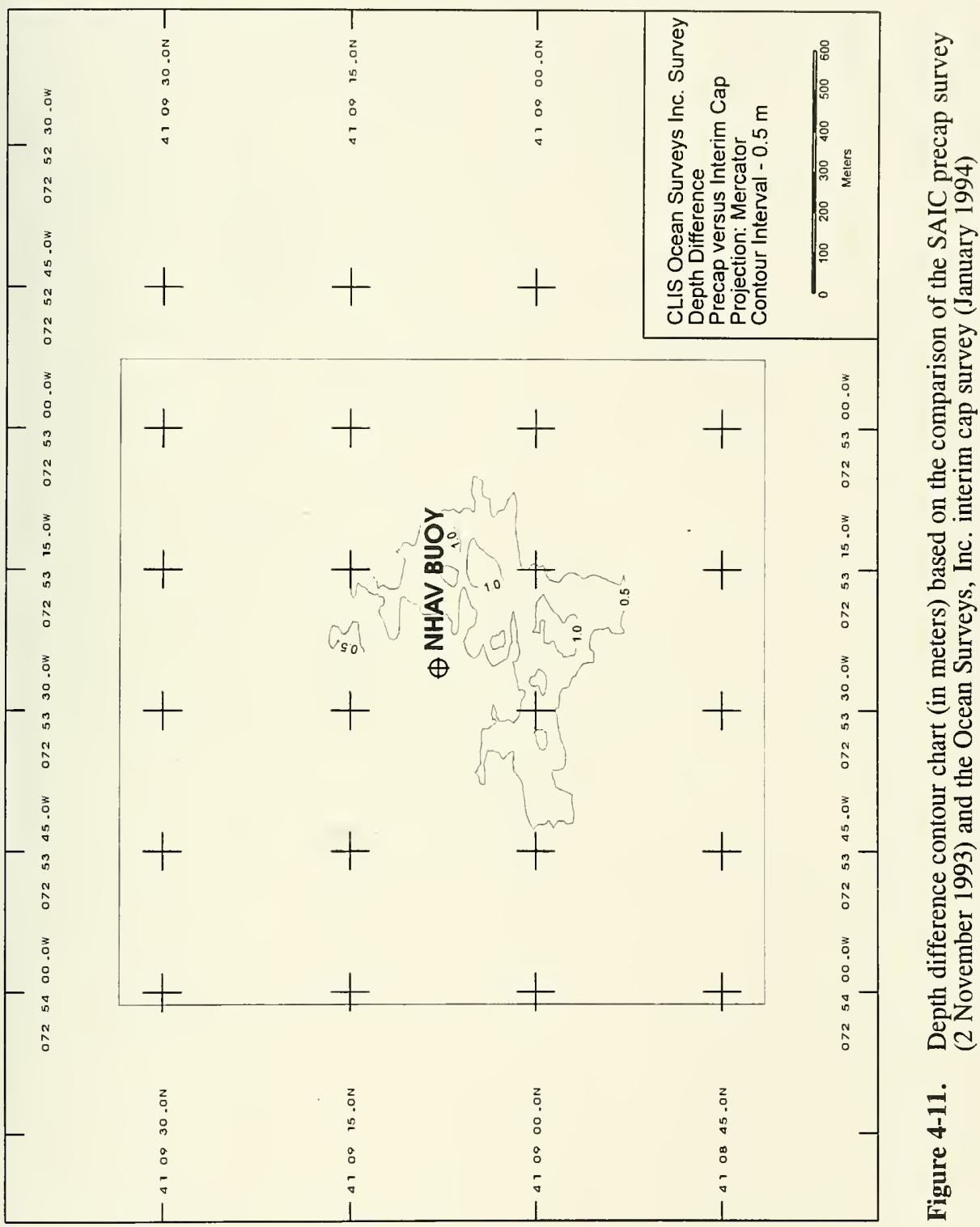




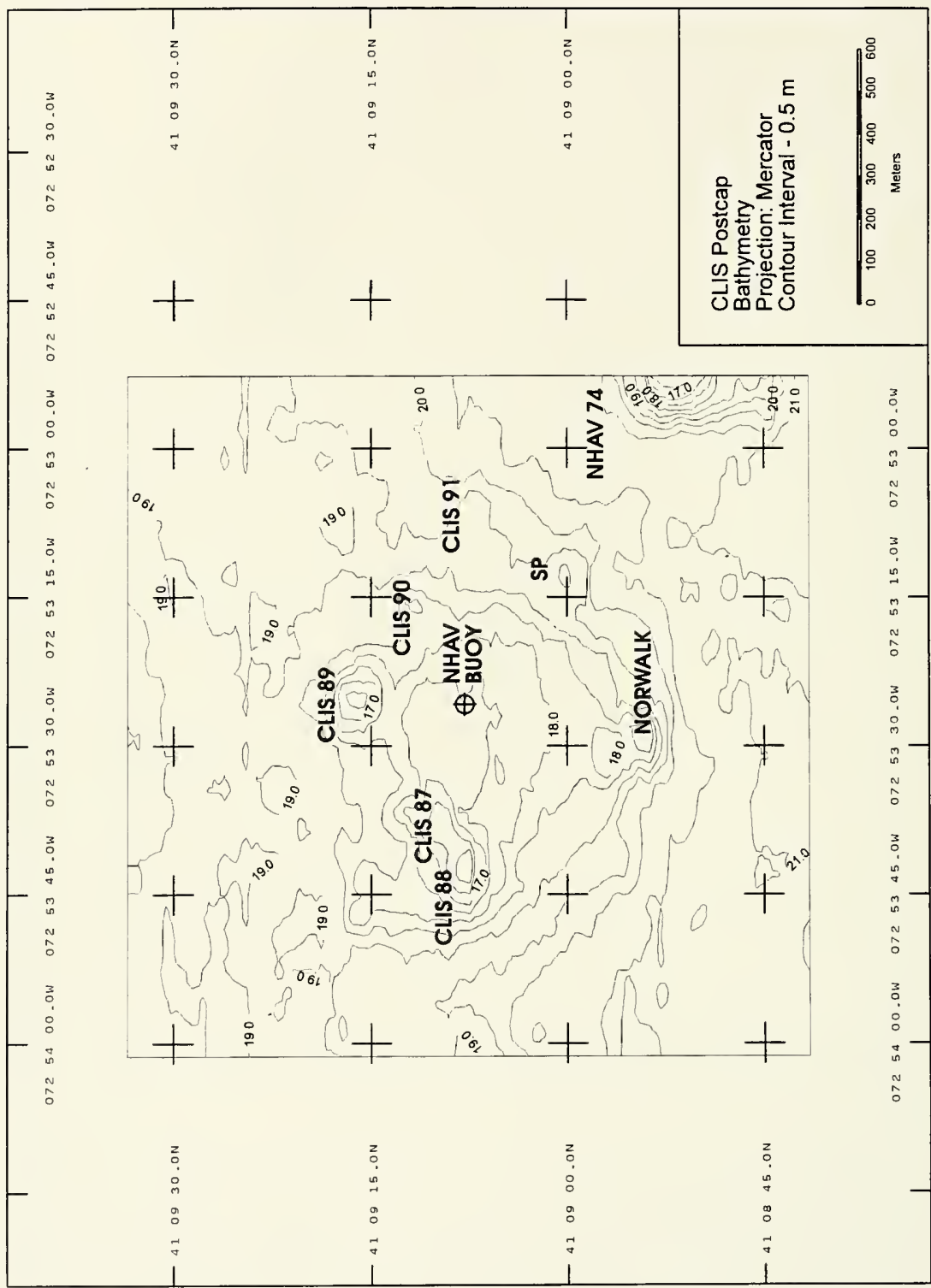

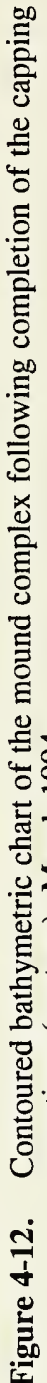




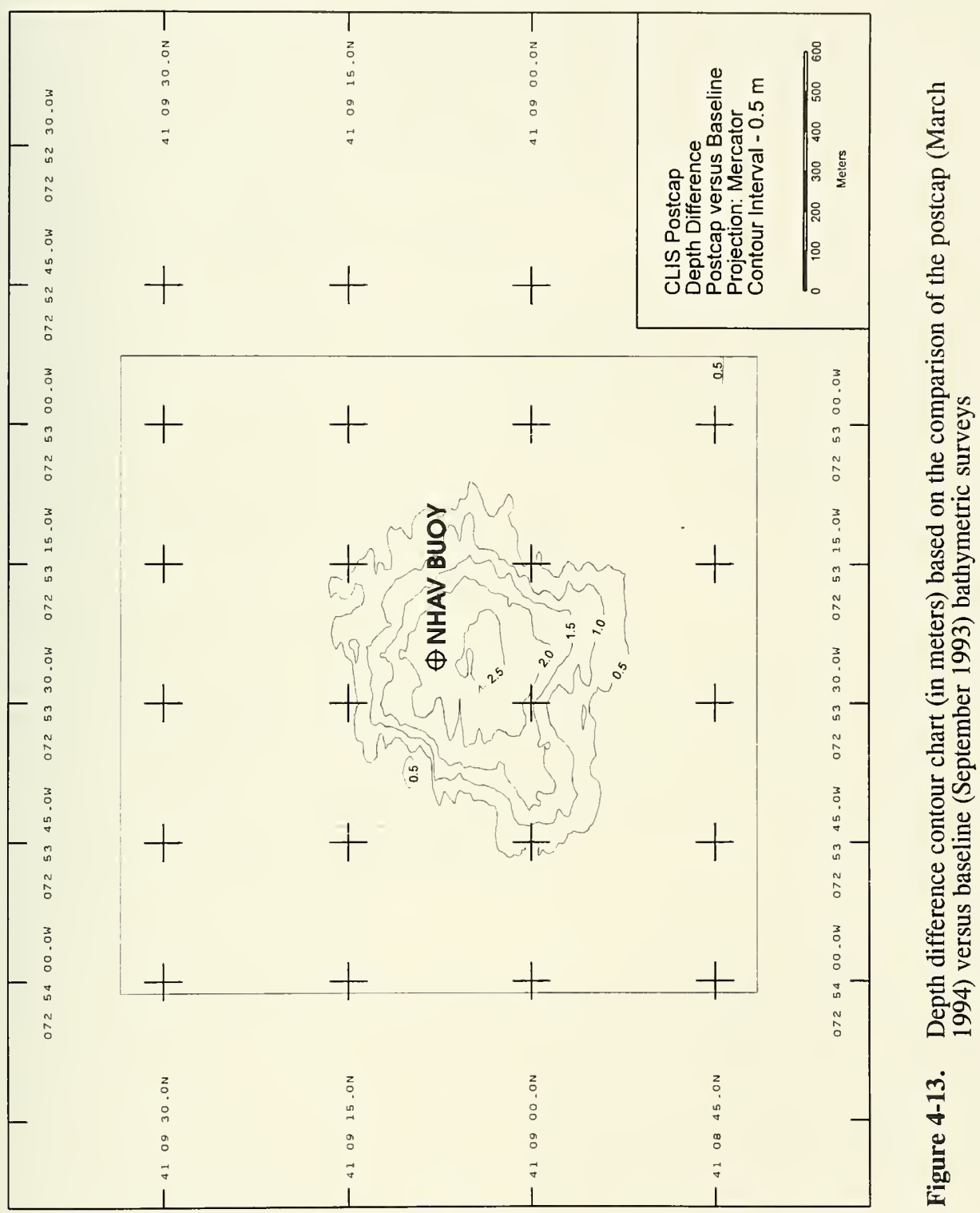




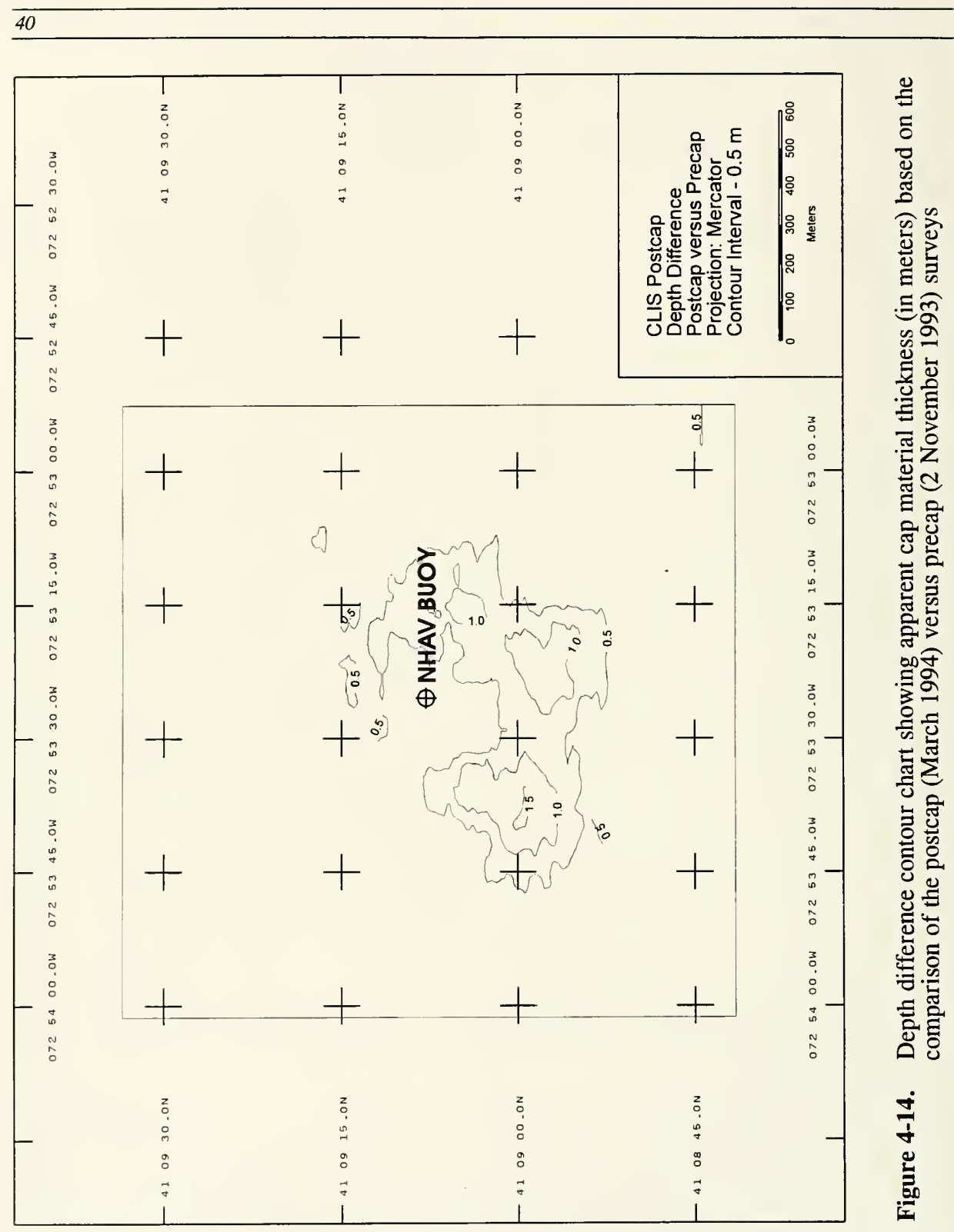


$278,000 \mathrm{~m}^{3}$. The comparison shows that federal cap material and the privately funded disposal and cap material were deposited on the southern side of the mound. The $76,000 \mathrm{~m}^{3}$ barge volume of additional federal cap material that was disposed to the northwest of the NHAV buoy location prior to the precap survey could not be accounted for in this comparison due to its deposition prior to the completion of the precap bathymetry.

\subsection{REMOTS ${ }^{\circledR}$ Sediment-Profile Surveys}

The REMOTS ${ }^{\circledR}$ baseline survey was conducted over the following inactive disposal mounds: NORWALK, CLIS-87, CLIS-88, CLIS-89, CLIS-90, SP, and the east-southeast valley. The results were used to assess the stability of the disposal mounds, allow accurate placement of dredged material in the basin formed by these mounds, and to document the status of the benthic community. In addition, NED planned to place a sediment cap over the experimental FVP mound in the northeast quadrant of CLIS using any excess CDM generated by the New Haven Capping Project. Therefore, triplicate photographs were also obtained at the historic FVP mound during the precap survey to allow comparisons in the event that excess CDM was available for deposition.

\subsubsection{Grain Size Distribution}

The major modal grain sizes over the majority of the mounds were very fine sand (4-3 phi) and some silt/clay ( $\geq 4$ phi) sediments at the CLIS- 87 and CLIS- 88 mounds. Fine sands (3-2 phi) were the major mode at a few of the stations located on the CLIS-89 and SP mounds. Several stations had surface layers of coarse sands and gravel. The major modal grain sizes at the FVP mound were very fine sands (4-3 phi); some silt/clay ( $\geq 4 \mathrm{phi}$ ) sediments were present at stations $50 \mathrm{E}, 50 \mathrm{~W}, 100 \mathrm{~W}$, and $100 \mathrm{~S}$. The range in grain size included gravel and very coarse sands to silt/clay.

\subsubsection{Prism Penetration Depth}

Dredged material often has different shear strengths and bearing capacities than ambient bottom sediments. The prism penetration depth into the bottom sediments depends on the force exerted by the optical prism and bearing strength of the sediment. The optical prism of the REMOTS ${ }^{\circledast}$ camera penetrates the bottom sediment under a static driving force imparted by the weight of the descending optical prism, camera housing, supporting mechanism, and weight packs. Soft silt/clay sediments will generally produce photographs showing two-thirds to full penetration $(15-20 \mathrm{~cm})$, while coarser grained material yields lesser penetration values (sands 8-12 cm; gravel 3-10 cm). 
During the baseline survey, penetration depths of individual replicates over the five sediment mounds (CLIS 87-88 complex, CLIS 89, CLIS 90, NORWALK, and SP) ranged from $5.50 \mathrm{~cm}$ to $20.70 \mathrm{~cm}$. The replicate-averaged mean penetration depths at the CLIS 87-88 mound complex ranged from 7.6 to $13.88 \mathrm{~cm}$; CLIS 897.80 to $17.64 \mathrm{~cm}$; CLIS 90 11.42 to $16.72 \mathrm{~cm}$; NORWALK 9.83 to $17.35 \mathrm{~cm}$; and SP 5.65 to $17.52 \mathrm{~cm}$. The penetration depths from individual replicates on the FVP mound ranged from $5.76 \mathrm{~cm}$ (sediments with a surface layers of gravel and coarse sands over very fine sands) to $15.83 \mathrm{~cm}$ (sediments with a surface layer of coarse and medium sands over silt/clay sediments).

\subsubsection{Mean Apparent Redox Potential Discontinuity (RPD) Depth}

Aerobic near-surface marine sediments typically have higher reflectance values relative to underlying hypoxic or anoxic sediments. Surface sands washed free of mud also have higher optical reflectance than underlying muddy sands. These differences in optical reflectance are readily apparent in REMOTS ${ }^{\circledR}$ images; the oxidized surface sediment contains particles coated with ferric hydroxide (an olive color associated with particles), while reduced and muddy sediments below this oxygenated layer are darker, generally gray to black. The boundary between the colored ferric hydroxide surface sediment and underlying gray to black sediment is called the apparent redox potential discontinuity (RPD). The replicate averaged RPD over the project area ranged from $1.10 \mathrm{~cm}$ to $3.06 \mathrm{~cm}$ during the baseline survey (Figure 4-15). The RPD values for the FVP mound during the precap survey ranged from $1.09 \mathrm{~cm}$ to $2.72 \mathrm{~cm}$.

\subsubsection{Infaunal Successional Stage}

The mapping of successional stages is based on the theory that organism-sediment interactions follow a predictable sequence after a major seafloor perturbation such as the disposal of dredged material (Rhoads and Germano 1990). All stations occupied during the baseline REMOTS ${ }^{\circledR}$ survey showed evidence of Stage I pioneering polychaetes (Figure 4-16). Stage I on Stage III communities were present at CLIS-87 and CLIS-88, CLIS-90, SP, and the east-southeast valley transect. Stage III taxa represent high-order successional stages typically found in low disturbance regimes. Evidence of Stage II taxa was present at CLIS-89, NORWALK, SP, and the east-southeast valley transect. Stage II organisms represent a transitional stage to Stage III and are characterized by tubicolous amphipods which can form extensive tube mats on the surface.

All stations occupied over the FVP mound during the NHAV 93 precap survey were characterized by presence of Stage I organisms. One replicate at FVP station 50W showed signs of Stage III activity, and was designed as Stage I on III. These results 


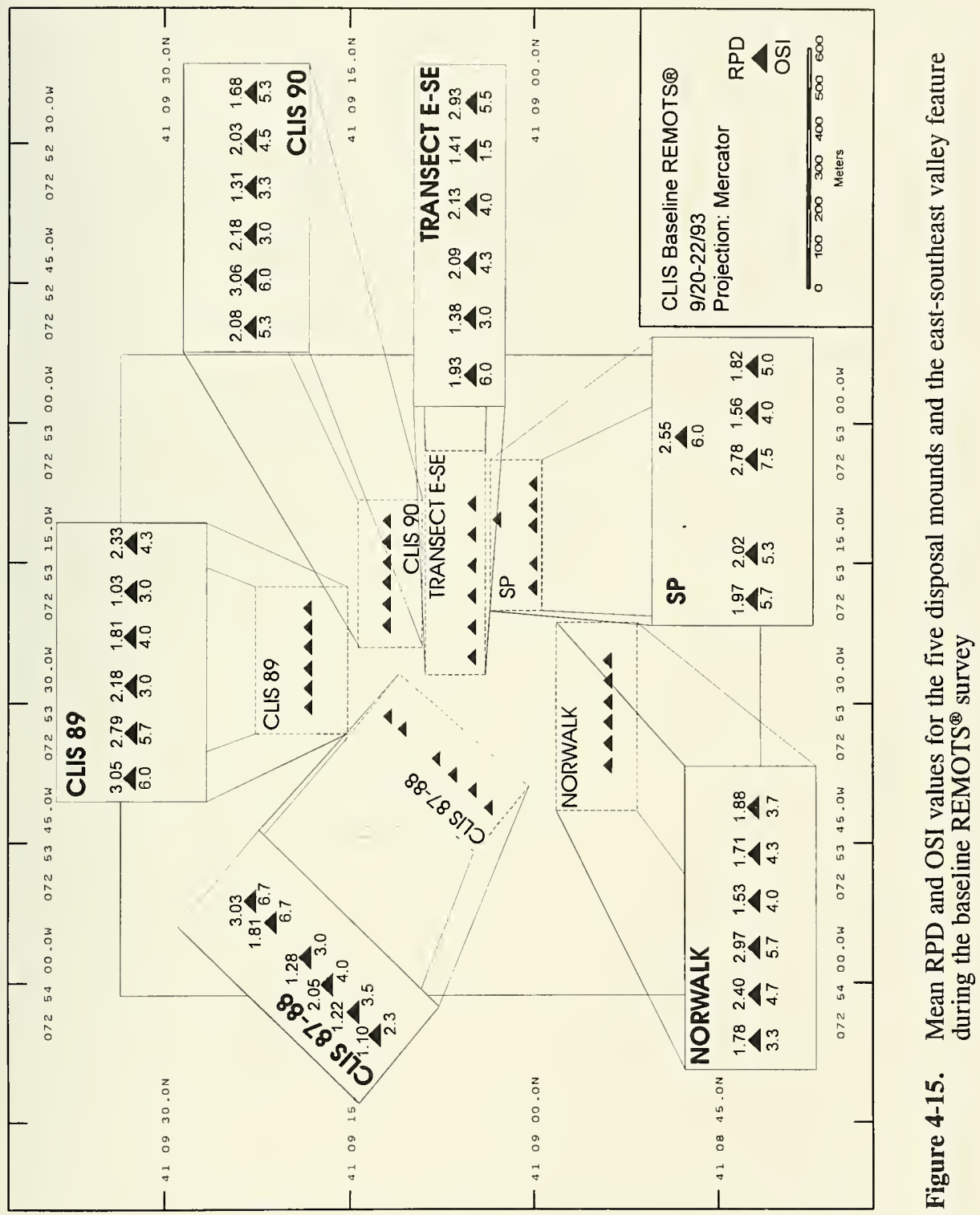




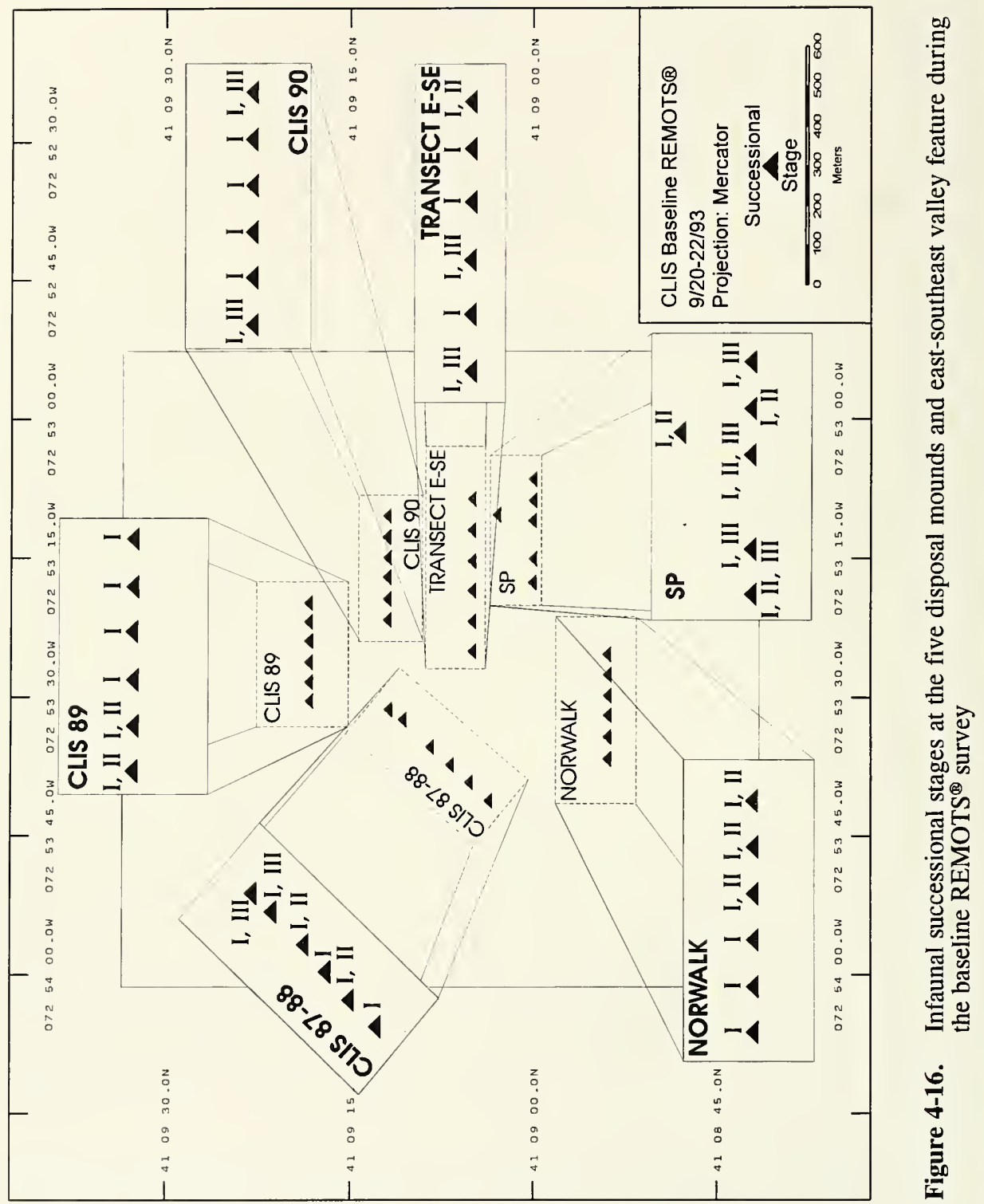


indicate a continued lack of a stable, benthic infaunal population over the entire FVP mound.

\subsubsection{Organism-Sediment Indices (OSI)}

The multiparameter Organism-Sediment Index (OSI), used to characterize gradients in habitat disturbance, can only be calculated at those stations where RPD and infaunal successional stage are also determined. The OSI is calculated automatically by the image analysis system after completion of all measurements from each REMOTS ${ }^{\circledR}$ image. Based on the compiled results of REMOTS ${ }^{\circledR}$ surveys during the past 10 years, OSI values of less than or equal to +6 are considered indicative of chronically stressed benthic habitats and/or those which have experienced recent disturbance such as disposal (Rhoads and Germano 1986). OSI values greater than +6 tend to represent relatively undisturbed habitats or habitats that have experienced a long period of recovery relative to bottom areas more recently disturbed. The replicate averaged OSI values over the disposal site ranged from 2.3 to 7.5 and were indicative of a patchy benthic environment in varying states of recovery (Figure 4-15). The NORWALK and SP mounds showed the most uniform values of OSI. Values at the FVP mound ranged from 3 to 5 with one value of 9; this was at the station with a Stage I on III community. 


\subsection{DISCUSSION}

The subaqueous capping of dredged material was introduced as a disposal technique to the DAMOS Program in 1979. The practices behind this disposal technique were improved during the early-1980s and continue to be employed in the successful completion of capping projects at CLIS, the New London Disposal Site (NLDS), and Portland Disposal Site (PDS; SAIC 1995). Over the years, data have shown that both sand and silt are effective capping materials. The low permeability and chemically adsorptive properties of silt constitute good capping material. Although sand caps provide greater resistance to erosion during storm events, a 0.5 to $1.0 \mathrm{~m}$ layer of silt was used as capping material at CLIS due to its similarity to the ambient grain size, relative abundance, and availability to the New Haven Capping Project.

The NHAV 93 disposal mound received an estimated barge volume of $1,159,000 \mathrm{~m}^{3}$ of material dredged from New Haven Harbor and the surrounding area as part of the New Haven Capping Project. The capping project conducted at CLIS during the 1993-1994 disposal season was atypical in several ways: 1) Dredged material was deposited in a depression formed by a ring of seven historic mounds to restrict the lateral spread of the UDM apron; 2) The resulting disposal mound was successfully capped with quantities of CDM less than the total volume of the UDM deposit; 3) A remarkable sequence of five precision bathymetric, two REMOTS ${ }^{\circledR}$ sediment-profile, and three geotechnical coring surveys were conducted by SAIC at various stages of NHAV 93 mound development, creating a comprehensive time-series dataset documenting the construction of the CAD mound.

The data collected over the NHAV 93 mound indicate that lateral containment of the UDM deposit was critical in the completion of the New Haven Capping Project. Utilization of the basin-like feature, created by the ring of disposal mounds, to receive large volumes of UDM for environmentally sound and cost-effective disposal is the culmination of many years of thoughtful planning and disposal. Since the inception of the DAMOS Program, a ten-year cycle of dredging and disposal operations has been established in the central Long Island Sound region. With the development of the NHAV 74, NHAV 83, and NHAV 93 mounds, NED has estimated that large scale dredging operations must be conducted in New Haven Harbor and the Quinnipiac River every ten years to maintain adequate depths for commercial, military, and private vessels (Morris 1994).

The ten-year time frame allows for the completion of many small dredging operations in regional harbors, channels, and docking facilities. The disposal of modest volumes of material aids in the preparation for large scale projects with the magnitude of 
the New Haven Capping Project. Dredged material generated by those smaller projects is now used to develop containment rings that concentrate deposition of large volumes of UDM and facilitate efficient capping. By continuing to build rings of closely spaced disposal mounds over the $6.85 \mathrm{~km}^{2}$ area of CLIS, a network of containment cells, similar to honeycombs, will be produced (Figure 5-1). Over time, this network of cells will minimize the surface area occupied by each dredged material deposit and therefore maximize the overall capacity of the site.

In the past, the management strategy at CLIS and other DAMOS disposal sites was to build many independent mounds over the given area of the disposal site. Each mound could be monitored individually, assessing mound stability, cap thickness, recolonization status, etc. Although this practice was highly successful, the overall capacity of the disposal site was reduced due to the unusable area between the discrete sediment mounds. This strategy changed at CLIS in 1983 with the placement of the SP mound to the northeast of the historic NORWALK mound (SAIC 1984). As dredging and disposal practices continued to improve, advancements in precision navigation and point deposition helped concentrate sediment mounds in smaller areas. By repositioning a taut-wire moored disposal buoy at the start of each disposal season, a ring of disposal mounds was formed and eventually completed in 1992 with the development of the CLIS 91 mound. At this time project plans for the large-scale New Haven Capping Project were being finalized.

The reported volumes provided by the DAMOS Disposal Barge Logs state that approximately $590,000 \mathrm{~m}^{3}$ of UDM was deposited at the NHAV buoy, followed by an estimated volume of $569,000 \mathrm{~m}^{3}$ of CDM. The wealth of data collected over the NHAV 93 project area suggests that the resulting mound is broad, stable, adequately capped, and exhibiting a CDM to UDM ratio of 0.96 to 1.0 (Morris 1994). In the past, CDM to UDM ratios varied from $2: 1$ to $6: 1$ when initiating a capping operation on a flat or gently sloping area of seafloor without natural (i.e., rock outcrops, glacial troughs) or artificial (i.e., disposal mound ring, geotextile fabrics) means of restricting the lateral dispersion of a UDM deposit (SAIC 1995). Lacking means of containment, the apron of UDM is free to spread into a wide, thin layer of material, increasing the amount of CDM required to completely cover the flanks of the mound.

The NHAV 93 capping project was the first in the New England region to utilize an artificial containment cell to control the spread of UDM. The use of the disposal mound ring at CLIS significantly reduced the outward migration of the UDM mound apron. As a result, cap material was distributed over a much smaller area, decreasing the total volume of CDM required to cap the inner harbor sediments. Dredging operations in urbanized areas may not produce an abundance of CDM for use in capping operations. However, the 


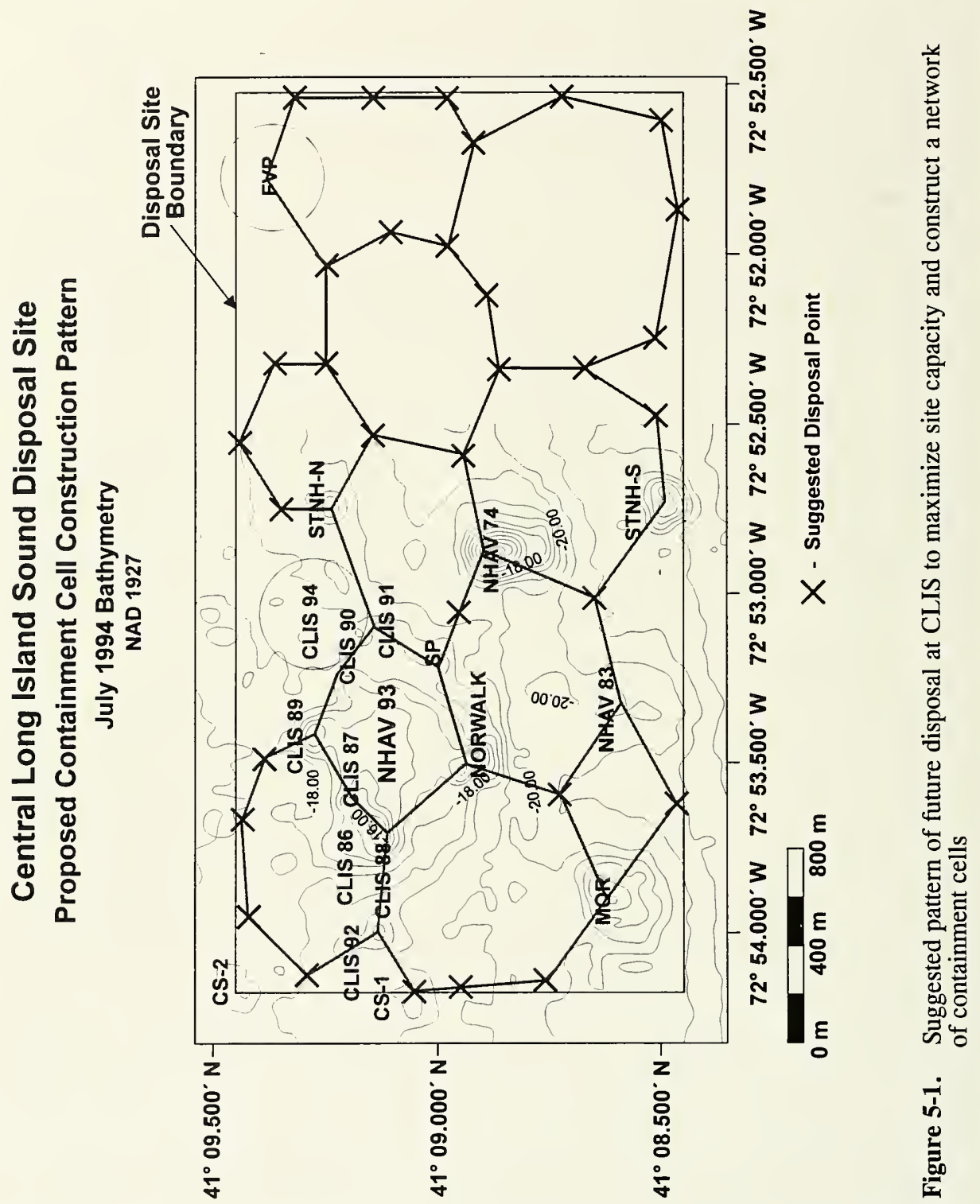


perfection of this disposal and containment technique allows NED to deposit moderate to large volumes of UDM, while requiring a minimum investment of CDM.

The strategic repetition of precision bathymetric, REMOTS ${ }^{\circledR}$, and geotechnical coring surveys was invaluable during the New Haven Capping Project. The five separate datasets allowed SAIC to document the progression of CAD mound development and advise NED upon the best course of action to achieve its ultimate goal. The results of each bathymetric survey provided a "snapshot" in time, allowing comparisons with previous surveys to document and quantify central mound consolidation, calculate overall growth of the CAD mound, and identify areas requiring additional cap material deposition. This comprehensive dataset also facilitates revisiting the various stages of the capping project to chronicle how disposal and oceanographic processes affected the dredged material, as well as to explore what knowledge of CAD mound construction was gained.

During the baseline survey, REMOTS ${ }^{\circledast}$ sediment-profile photography was used to estimate the shear strength, as well as document the successional status of the containment ring. The flanks of the UDM mound were mapped by REMOTS ${ }^{\circledR}$ within the containment basin during the precap survey of the NHAV 93 mound. These data were used to ensure accurate placement of the dredged material during disposal operations and permit the calculation of target capping points along the mound apron (Figure 4-6). REMOTS ${ }^{\circledR}$ photography continues to be used to detect changes in various physical and biological parameters on the surface of the NHAV 93 mound.

The surface layer shear strengths of the five mounds sampled during the baseline survey indicated that significant de-watering and consolidation had occurred in the surface sediments. The larger grain-sized and densely packed sediment deposits displayed higher shear strengths, indicating the potential to contain a ridge of new dredged material while maintaining the mound integrity. No structural failure was detected within the sevenmound containment ring during any of the five bathymetric surveys.

URI estimated the relative consolidation of sediments occurring between the precap, interim cap, and postcap surveys using both theoretical models and data from the geotechnical cores. These estimates were required to determine cap material requirements; actual cap thickness was masked by consolidation of both the basement material (ambient sediments and historic dredged material) and the UDM deposit. Cores collected immediately following the construction of the mound included the basement material, UDM, and CDM. Results were used to establish the initial geotechnical characteristics of the completed mound. These data were used as a reference for future geotechnical and bathymetric surveys. Numerical computations will also be performed on settlement and volume changes. 
Following UDM disposal, the mound was $2.5 \mathrm{~m}$ in height and $510 \mathrm{~m}$ in diameter with a calculated volume of $312,000 \mathrm{~m}^{3}$ based on comparisons of the baseline and precap bathymetric surveys. The final CAD mound is centered approximately $125 \mathrm{~m}$ to the south of the NHAV buoy location (Figure 4-13). The total volume of cap material accounted for by bathymetry was $402,000 \mathrm{~m}^{3}$, the diameter of the mound expanded to $800 \mathrm{~m}$, and the mound height remained at $2.5 \mathrm{~m}$ due to significant consolidation of the underlying UDM deposit. According to DAMOS barge disposal logs, the total volume of dredged material was $1,159,000 \mathrm{~m}^{3}$; however, the total volume accounted for by bathymetry was $714,000 \mathrm{~m}^{3}$ ( $62 \%$ of the estimated barge volume).

Results of previous DAMOS monitoring surveys have shown that accumulations of dredged material less than $20 \mathrm{~cm}$ thick in the flanks of a disposal mound are typically deposited in layers too thin to be detected by standard bathymetric techniques. The $38 \%$ difference in final volumes between bathymetric analysis and disposal logs is accounted for by consolidation of the underlying UDM deposit and the limits of the acoustic survey. Due to the complex scheduling of disposal activities during this project, it is difficult to determine what volumes of contaminated and cap material were present during each survey.

The depth difference comparison between the precap and the postcap surveys provides the best indication of the overall distribution of cap material. This comparison indicates an apparent lack of cap material in the northwestern quadrant of the final disposal mound (Figure 4-14). However, disposal records indicate that $76,000 \mathrm{~m}^{3}$ of cap material was disposed in this quadrant prior to the precap survey making it undetectable in the precap/postcap comparisons. In addition, subbottom profiling data and geotechnical cores collected over the NHAV 93 mound in July 1994 detected 0.5 to $0.75 \mathrm{~m}$ of silt cap material over the northwestern flank (Figures 5-2 and 5-3; Morris 1994).

Results of the REMOTS ${ }^{\circledR}$ baseline survey showed that recolonization of the bottom invertebrate community from the disturbance of historic disposal operations has proceeded at a rate typical for open-water dredged material sites. Successional stages were dominated by pioneering Stage I polychaetes with evidence of more mature taxa in the Stage I to Stage II and Stage I on Stage III communities. Stage II taxa represent a transitional sere between Stage I and III and are associated with recovery of a disturbed benthic habitat (Rhoads and Germano 1986). Stage III taxa generally represent high-order successional stages typically found in low disturbance regimes. Organism-Sediment Indices were variable and indicative of a patchy benthic environment. 


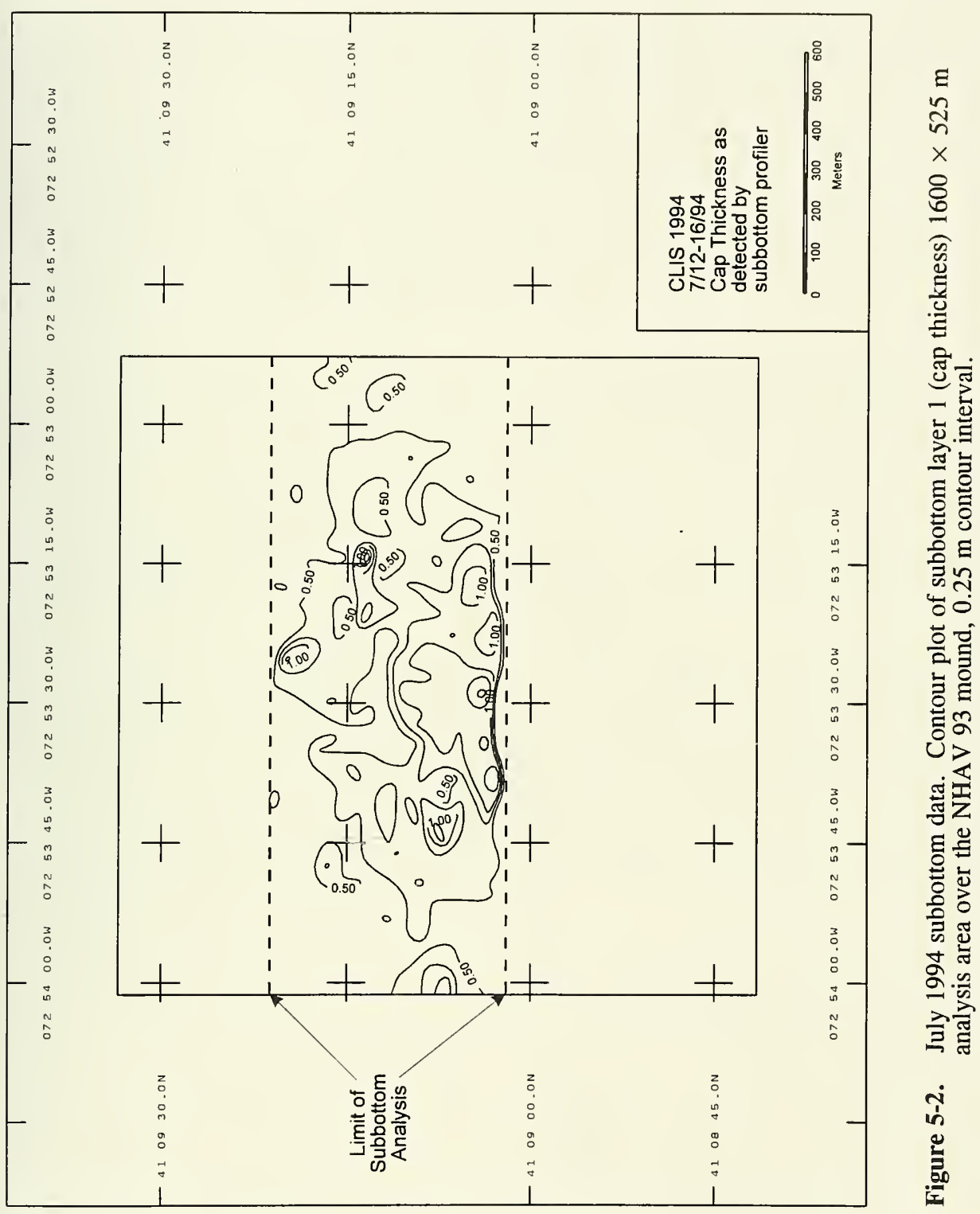




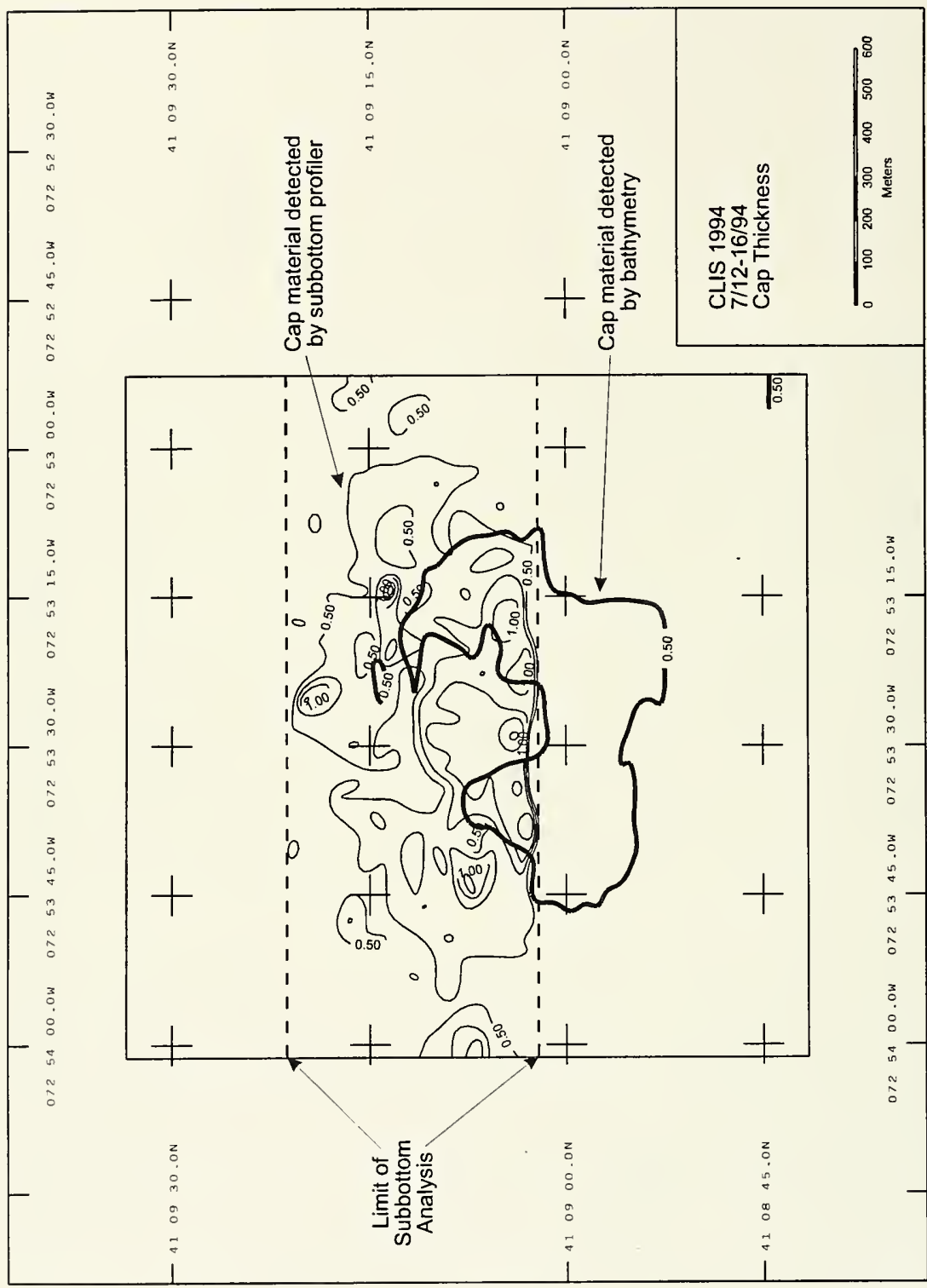

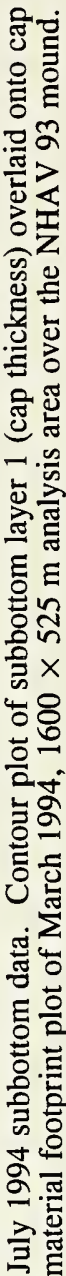

in 
During the November 1993 precap REMOTS ${ }^{\circledast}$ survey of the FVP mound, there was a noticeable lack of Stage II and Stage III benthic infaunal activity. Although plans were made to cap the historic UDM mound, no excess CDM was available from the New Haven Capping Project to begin the placement of a sediment cap over the FVP mound. Another series of REMOTS ${ }^{\circledR}$ photographs collected in September 1995 indicate an increase in Stage III individuals within the surface sediments (Morris and Murray 1995). A total of ten stations displayed evidence of Stage III assemblages, compared to the single replicate of station $50 \mathrm{~W}$ in 1993 . However, the majority of those ten stations lie 200 to $300 \mathrm{~m}$ from the center of the mound, correlating to previous observations regarding the patchy benthic infaunal community near the center of the FVP mound.

The original objective of FVP was to field verify existing predictive techniques for evaluating the environmental consequences of dredged material disposal under aquatic, intertidal (wetland), and upland conditions (Murray and Carey 1993). The mound is an uncapped UDM deposit formed by the placement of Black Rock Harbor sediments placed in the northeast corner of CLIS during the 1982-83 disposal season. Designed as a sixyear, cooperative research project between the US Army Corps of Engineers, Waterways Experiment Station (WES) and the US Environmental Protection Agency (EPA), the UDM sediments have been monitored periodically for changes in benthic infaunal population and contaminant content.

Now that the WES/EPA experimentation has concluded, plans have been made to cap the mound in order to isolate the UDM from the marine environment. Without the deposition of cap material during the New Haven Capping Project, an opportunity still exists to conduct a comprehensive physical, chemical, and biological assessment of the experimental mound 13 years post-disposal. An intensive bioaccumulation study on the invertebrate species inhabiting the sediments could determine the current amount of chemical uptake within the benthic infauna, as well as explore the stress and susceptibility levels of the organisms occupying the various domains of the mound. 


\subsection{CONCLUSIONS}

Based on acoustically detected changes in depth at the NHAV buoy location, disposal and capping operations formed a CAD mound with a diameter of $800 \mathrm{~m}$ and height of $2.5 \mathrm{~m}$. Depth difference calculations between the interim disposal and precap surveys detected a $100 \mathrm{~m}$ wide pocket of consolidation over the mound apex. It was determined that the majority of the material shifted to the northeast, forming a $150 \mathrm{~m}$ wide plateau at the top of the UDM mound. The primary factor causing the structural failure of the apex was likely to be the initial placement of CDM over the northwest quadrant of the NHAV 93 mound, building the apex beyond the critical angle of repose, causing redistribution of material downslope. A contributing factor to the collapse of the mound apex could have been the subsurface consolidation of the UDM deposit due to de-watering.

A question had existed concerning the coverage of UDM in the northwestern quadrant of the NHAV 93 mound due to conflicts in the schedule of capping and survey operations. However, DAMOS disposal logs indicate an estimated barge volume of $76,000 \mathrm{~m}^{3}$ was released over cap placement points $\mathrm{A}, \mathrm{F}$, and $\mathrm{J}$ before the completion of the precap survey. In addition, subbottom and geotechnical core data collected over the northern portion of the NHAV 93 mound in July 1994 indicate that 0.5 to $0.75 \mathrm{~m}$ of cap material is present northwest of the buoy location. Recolonization over the entire surface of the new CAD mounds is expected to progress at a rate typical of open-water dredged material disposal sites.

This capping project demonstrated the successful execution of a long-term management strategy at the most active disposal site in New England. The strategy included the thoughtful placement of small to moderate volumes of dredged material in order to support the containment of large volumes of UDM and effectively isolate it from further interaction with the marine environment. Also, the continued use of this management approach will concentrate disposal into the formation and subsequent filling of containment cells, maximizing the finite capacity of the $6.85 \mathrm{~km}^{2}$ disposal site. Although all primary indications suggest the attainment of all of NED's goals, monitoring at the NHAV 93 mound should continue for the next several years to assess biological recovery and long-term cap integrity (Morris 1994; Germano et al. 1994).

The wealth of data generated by the repetitive survey operations during CAD mound construction and annual monitoring are providing a great deal of insight into the processes that continue to affect this and other dredged material mounds. The inspection of cap integrity and quantification of overall consolidation could lead to answers pertaining to dredged material mass balance, consolidation rates, material slumping, material dewatering, and physical changes in basement material. 


\subsection{REFERENCES}

Bohlen, W. F.; Cohen, D. R.; Howard-Strobel, M. M.; Morton, E. T. 1994. DAMOS New Haven dredge monitoring cruise log summary, October 25-November 18, 1993. University of Connecticut, Marine Sciences Department, Avery Point, CT. Submitted to SAIC, Newport, RI.

EPA/USACE. 1991. Evaluation of dredged material proposed for ocean disposal, testing manual. Publication 503/8-91/001. US Environmental Protection Agency, Office of Marine and Estuarine Protection, Washington, D.C. and Dept. of the Army, US Corps of Engineers, Washington, D.C.

Fredette, T. J. 1994. Disposal site capping management: New Haven Harbor. Reprinted from Dredging '94, Proceedings of the Second International Conference, November 13-16, 1994. US Army Corps of Engineers, New England Division, Waltham, MA.

Germano, J. D.; Rhoads, D. C.; Lunz, J. D. 1994. An integrated, tiered approach to monitoring and management of dredged material disposal sites in the New England Region. DAMOS Contribution No. 87 (SAIC Report No. SAIC-90/7575\&234). US Army Corps of Engineers, New England Division, Waltham, MA.

HMM Associates, Inc. 1993. Consultants for the US Army Corps of Engineers. Concord, MA.

Lawless, W., Chief, Regulatory Divisions Operations Directorate for USACE New England Division. [Letter to Chief, Navigation Division]. 1991 December 23.

Morris, J. T. 1994. Monitoring cruise at the Central Long Island Sound Disposal Site, July 1994. SAIC Report No. 327. Draft report submitted to US Army Corps of Engineers, New England Division, Waltham, MA.

Morris, J. T.; Murray, P. M. 1995. Monitoring cruise at the Central Long Island Sound Disposal Site, September 1995: data report. SAIC Report No. 360. Data report submitted to US Army Corps of Engineers, New England Division, Waltham, MA.

Murray, P. M.; Carey, D. A. 1993. Summary of monitoring results at the Field Verification Program aquatic disposal mound. SAIC Report No. 287. Technical report submitted to US Army Corps of Engineers, New England Division, Waltham, MA. 
Murray, P. M.; Selvitelli, P. 1996. DAMOS navigation and bathymetry standard operating procedures. SAIC Report No. 290. Final report submitted to US Army Corps of Engineers, New England Division, Waltham, MA.

Naval Underwater Systems Center (NUSC). 1979. Disposal Area Monitoring System (DAMOS) annual data report - 1978. Submitted to US Army Corps of Engineers, New England Division, Waltham, MA.

New England River Basins Commission (NERBC). 1980. Interim plan for the disposal of dredged material from Long Island Sound. New England River Basins Commission. Boston, MA. pp. 1-55.

Rhoads, D. C.; Germano, J. D. 1986. Interpreting long-term changes in benthic community structure: a new protocol. Hydrobiologia. 142:291-308.

Rhoads, D. C.; Germano, J. D. 1990. The use of REMOTS ${ }^{\circledR}$ imaging technology for disposal site selection and monitoring. In: Demars, K.; Chaney, R. eds. Geotechnical engineering of ocean waste disposal. ASTM Symposium Volume, January 1989, Orlando, Fla., pp. 50-64.

SAIC. 1984. DAMOS summary of program results 1981-1984: volume II, part B, section II: Central Long Island Sound ongoing surveys. DAMOS Contribution No. 46 (SAIC Report No. 84/7521\&C46). US Army Corps of Engineers, New England Division, Waltham, MA.

SAIC. 1985. Standard operating procedure manual for DAMOS monitoring activities: volume I and volume II. DAMOS Contribution No. 48 (SAIC Report No. SAIC85/7516\&C48)). US Army Corps of Engineers, New England Division, Waltham, MA.

SAIC. 1995. Sediment capping of subaqueous dredged material disposal mounds: an overview of the New England experience 1979-1993. DAMOS Contribution No. 95 (SAIC Report No. SAIC-90/7573\&C84). US Army Corps of Engineers, New England Division, Waltham, MA.

Silva, A. J.; Brandes, H. G.; Veyera, G. E. 1994a. Geotechnical characterization: coring and core processing summary. DAMOS Project Central Long Island Sound, New Haven Harbor Maintenance 1993-1994. Draft report submitted to SAIC, Newport, RI. Available from: University of Rhode Island, Narragansett, RI.

Silva, A. J.; Brandes, H. G.; Veyera, G. E. 1994b. Geotechnical laboratory testing summary. DAMOS Project Central Long Island Sound, New Haven Harbor 
Maintenance 1993-1994. Draft report submitted to SAIC, Newport, RI. Available from: University of Rhode Island, Narragansett, RI. 

aerobic, 55

anoxia, 55

barge, viii, $12,24,54$ disposal, 24

benthos, $7,16,22,29,32,54,56,59$

ampeliscids, viii, 1, 22

amphipod, 56

bivalve, 22

polychaete, 22,56

bioassay, viii, 1, 22

body burden

bioaccumulation, 22, 23

bioassay, viii, 1, 22

boundary roughness, 29

buoy, viii, I, 6, 7, 12, 24, 27, 32, 44, 54

disposal, viii, 6

capping, viii, $x, 1,5,6,7,22,23,24,25,27,29,32$, $36,39,44,54$

Central Long lsland Sound (CLIS)

FVP, 32, 54, 55, 56, 59

MQR, 1

Norwalk (NOR), 1, 7

conductivity, 29

consolidation, $x, 6,35,39$

containment, viii, $1,7,29,36$

contaminant, $x, 14,22$

New England River Basin Commission (NERBC), 18,20

CTD meter, 29

density, 35

deposition, viii, 1, 36, 39, 44, 54

dispersion, 6, 7

disposal site

Central Long lsland Sound (CLIS), viii, 1, 6, 7, 8, $10,19,24,36,54,55,56$

fish, 14

fisheries, 14

grain size, 14, 24, 29, 35, 54

habitat, 59

methane, 29 mud clast, 29

New England River Basin Commission (NERBC), 18, 20

oil and grease, 20

organics

oil and grease, 20

polyaromatic hydrocarbon (PAH), 18, 19, 22, 24

polychlorinated biphenyl (PCB), 18, 24

total organic carbon, 14

recolonization, $\mathrm{x}, 32$

reference area, 19

REMOTS $\otimes$, viii, $x, 2,5,6,29,30,32,54,55,56,59$

boundary roughness, 29

Organism-Sediment Index (OSI), 30, 59

redox potential discontinuity (RPD), 29, 55

RPD

REMOTS $\otimes$, redox potential discontinuity (RPD), $29,55,59$

salinity, 29

sediment

chemistry, 22,24

clay, $14,20,54,55$

gravel, 54,55

plume, 6

sand, $14,18,54,55$

silt, 14, 20, 54, 55

sediment sampling

cores, ix, $x, 2,5,6,24,32,35$

grabs, ix, x, 2, 5, 6, 32, 35

shore station, 28

succession

pioneer stage, 56

successional stage, $29,56,59$

survey

baseline, viii, x, 2, 5, 6, 28, 29, 30, 32, 35, 36, 39, $44,54,55,56$

bathymetry, viii, x, 1, 5, 6, 28, 29, 35, 36, 39, 44, 54

postdisposal, 7

predisposal, 1, 2, 5, 36

REMOTS $\otimes, 32,56,59$

subbottom, $\mathrm{X}$

temperature, 29 
tide, $28,29,44$

toxicity, 23

trace metals, 18, 22, 24

arsenic (As), 18, 20

cadmium (Cd), 18, 20, 24

chromium $(\mathrm{Cr}), 18,20$

copper (Cu), 18, 21, 24

lead $(\mathrm{Pb}), 18,21$

mercury $(\mathrm{Hg}), 18,21$

nickel $(\mathrm{Ni}), 18,21$

vanadium (V), 5, 12, 24, 27

zinc $(\mathrm{Zn}), 12,18,24,27$

volume

difference, $x$

waves, 28,36 


\section{APPENDIX A}

Sediment Chemistry Results 



\section{Appendix A Sediment Chemistry Results}

Appendix A Table 1. Sediment Chemistry Results (Dry Weight) for the Inner Federal Navigation Channel, New Haven Harbor 1993

Appendix A Table 2. Sediment Chemistry Results (Dry Weight) for the Outer Federal Navigation Channel, New Haven Harbor 1993

Appendix A Table 3. Sediment Chemistry Results (Dry Weight) for Gulf Oil, New Haven Harbor 1993

Appendix A Table 4. Sediment Chemistry Results (Dry Weight) for Northeast Petroleum, New Haven Harbor 1993

Appendix A Table 5. Sediment Chemistry Results (Dry Weight) for the New Haven Terminal, New Haven Harbor 1993

Appendix A Table 6. Sediment Chemistry Results (Dry Weight) for Mobil Oil, New Haven Harbor 1993

Appendix A Table 7. Sediment Chemistry Results (Dry Weight) for Wyatt Incorporated, New Haven Harbor 1993 


\section{Appendix A Table 1}

Sediment Chemistry Results (Dry Weight) for the Inner Federal Navigation Channel, New Haven Harbor 1993

\begin{tabular}{|c|c|c|c|c|}
\hline INNER HARBOR & $\overline{\bar{A}}$ & $\overline{\mathrm{B}}$ & $\overline{\bar{C}}$ & $\bar{D}$ \\
\hline $\begin{array}{l}\text { Station Latitude } \\
\text { Station Longitude }\end{array}$ & $\begin{array}{l}42^{\circ} 17.94^{\prime} \\
72^{\circ} 54.50^{\prime}\end{array}$ & $\begin{array}{l}42^{\circ} 17.73^{\prime} \\
72^{\circ} 54.60^{\prime}\end{array}$ & $\begin{array}{l}41^{\circ} 17.45^{\prime} \\
72^{\circ} 54.75^{\prime}\end{array}$ & $\begin{array}{l}41^{\circ} 17.23^{\prime} \\
72^{\circ} 54.69^{\prime}\end{array}$ \\
\hline \multicolumn{5}{|l|}{ GRAIN SIZE } \\
\hline \%Silt/clay & 93 & 97 & 96 & 96 \\
\hline$\% \mathrm{TOC}$ & 1.20 & 0.96 & 0.82 & 0.55 \\
\hline \multicolumn{5}{|l|}{ METALS (ppm) } \\
\hline As & 13.8 & 0.6 & 0.9 & 0.1 \\
\hline $\mathrm{Cd}$ & 7.7 & 0.9 & 3.1 & 2.9 \\
\hline $\mathrm{Cr}$ & 163 & 168 & 168 & 266 \\
\hline $\mathrm{Cu}$ & 109 & 99 & 111 & 279 \\
\hline $\mathrm{Hg}$ & 0.15 & 0.02 & 0.18 & 0.10 \\
\hline $\mathrm{Ni}$ & 45 & 75 & 82 & 71 \\
\hline $\mathrm{Pb}$ & 67 & 98 & 32 & 47 \\
\hline $\mathrm{Zn}$ & 595 & 174 & 136 & 81 \\
\hline \multicolumn{5}{|l|}{ PESTICIDES (ppm) } \\
\hline Aldrin & $<0.01$ & $<0.01$ & $<0.01$ & $<0.01$ \\
\hline Chlordane & $<0.40$ & $<0.40$ & $<0.40$ & $<0.40$ \\
\hline pp-DDT,DDE,DDD & $<0.02$ & $<0.02$ & $<0.02$ & $<0.02$ \\
\hline Dieldrin & $<0.01$ & $<0.01$ & $<0.01$ & $<0.01$ \\
\hline Endosulfan I,II & $<0.01$ & $<0.01$ & $<0.01$ & $<0.01$ \\
\hline Endosulfan sulfate & $<0.04$ & $<0.04$ & $<0.04$ & $<0.04$ \\
\hline Endrin & $<0.01$ & $<0.01$ & $<0.01$ & $<0.01$ \\
\hline Endrin aldehyde & $<0.04$ & $<0.04$ & $<0.04$ & $<0.04$ \\
\hline Heptachlor & $<0.01$ & $<0.01$ & $<0.01$ & $<0.01$ \\
\hline Heptachlor epoxide & 0.46 & 1.42 & 1.79 & 1.94 \\
\hline Toxaphene & $<0.50$ & $<0.50$ & $<0.50$ & $<0.50$ \\
\hline alpha-BHC & $<0.01$ & $<0.01$ & $<0.01$ & $<0.01$ \\
\hline beta-BHC & $<0.01$ & $<0.01$ & $<0.01$ & $<0.01$ \\
\hline gamma-BHC & $<0.01$ & $<0.01$ & $<0.01$ & $<0.01$ \\
\hline Total BHC & $<0.01$ & $<0.01$ & $<0.01$ & $<0.01$ \\
\hline PCBs (ppb) & $<100$ & $<100$ & $<100$ & $<100$ \\
\hline
\end{tabular}


Appendix A Table 1 (cont.)

\begin{tabular}{|c|c|c|c|c|}
\hline PAHs (ppm) & A & B & $\mathrm{C}$ & $\mathrm{D}$ \\
\hline \multicolumn{5}{|l|}{ Low Molecular Weight } \\
\hline Napthalene & 0.20 & 0.18 & 0.31 & 0.19 \\
\hline Acenapthene & 0.11 & 0.05 & 0.05 & 0.03 \\
\hline Acenaphthylene & $<0.03$ & $<0.03$ & $<0.04$ & $<0.04$ \\
\hline Fluorene & 0.17 & 0.09 & 0.10 & $<0.04$ \\
\hline Phenanthrene & 0.69 & 0.34 & 0.55 & 0.29 \\
\hline Anthracene & 0.27 & 0.11 & 0.13 & 0.08 \\
\hline \multicolumn{5}{|l|}{ High Molecular Weight } \\
\hline Fluoranthene & 1.52 & 0.82 & 1.31 & 0.82 \\
\hline Pyrene & 2.39 & 1.12 & 1.38 & 0.87 \\
\hline Benzo(a)anthracene & 0.71 & 0.32 & 0.47 & 0.28 \\
\hline Chrysene & 0.73 & 0.41 & 0.60 & 0.36 \\
\hline Benzo(b)fluoranthene & 0.63 & 0.36 & 0.70 & 0.39 \\
\hline Benzo(k)fluoranthene & 0.62 & 0.36 & 0.46 & 0.38 \\
\hline Benzo(a)pyrene & 0.47 & 0.32 & 0.45 & 0.27 \\
\hline Benzo(g,h,i)perylene & $<0.03$ & $<0.03$ & 0.31 & 0.19 \\
\hline Dibenzo(a,h)anthracene & $<0.03$ & $<0.03$ & $<0.04$ & $<0.04$ \\
\hline Indeno(1,2,3-cd)pyrene & $<0.03$ & $<0.03$ & $<0.04$ & $<0.04$ \\
\hline
\end{tabular}




\section{Appendix A Table 2}

Sediment Chemistry Results (Dry Weight) for the Outer Federal Navigation Channel, New Haven Harbor 1993

\begin{tabular}{|c|c|c|c|c|c|c|}
\hline OUTER HARBOR & $\bar{E}$ & $\mathrm{~F}$ & $\bar{G}$ & H & T & 丁 \\
\hline $\begin{array}{l}\text { Station Latitude } \\
\text { Station Longitude }\end{array}$ & $\begin{array}{l}41^{\circ} 16.94^{\prime} \\
72^{\circ} 54.80^{\prime}\end{array}$ & $\begin{array}{l}42^{\circ} 16.39^{\prime} \\
72^{\circ} 54.69^{\prime}\end{array}$ & $\begin{array}{l}41^{\circ} 15.60^{\prime} \\
72^{\circ} 54.81^{\prime}\end{array}$ & $\begin{array}{l}41^{\circ} 15.16^{\prime} \\
72^{\circ} 54.97^{\prime}\end{array}$ & $\begin{array}{l}41^{\circ} 14.50^{\prime} \\
72^{\circ} 54.97^{\prime}\end{array}$ & $\begin{array}{l}41^{\circ} 13.54^{\prime} \\
72^{\circ} 54.69^{\prime}\end{array}$ \\
\hline \multicolumn{7}{|l|}{ GRAIN SIZE } \\
\hline$\%$ Silt/clay & 95 & 97 & 97 & 99 & 98 & 77 \\
\hline$\%$ TOC & 0.60 & 0.64 & 0.40 & 0.68 & 0.76 & 0.50 \\
\hline \multicolumn{7}{|l|}{ METALS (ppm) } \\
\hline As & $<0.03$ & 12.6 & 3.9 & 1.4 & 1.5 & 1.9 \\
\hline $\mathrm{Cd}$ & 4.2 & 1.1 & 3.9 & 1.1 & 0.76 & 0.62 \\
\hline $\mathrm{Cr}_{\mathrm{r}}$ & 320 & 220 & 278 & 318 & 162 & 151 \\
\hline $\mathrm{Cu}$ & 260 & 340 & 258 & 420 & 149 & 153 \\
\hline $\mathrm{Hg}$ & 0.19 & 0.22 & 0.24 & 0.24 & 0.28 & 0.38 \\
\hline $\mathrm{Ni}$ & 36 & 76 & 96 & 181 & 60 & 63 \\
\hline $\mathrm{Pb}$ & 90 & 100 & 80 & 98 & 106 & 112 \\
\hline $\mathrm{Zn}$ & 101 & 440 & 117 & 218 & 321 & 334 \\
\hline \multicolumn{7}{|l|}{ PESTICIDES (ppm) } \\
\hline Aldrin & $<0.01$ & 0.13 & $<0.01$ & $<0.01$ & $<0.01$ & 0.21 \\
\hline Chlordane & $<0.40$ & $<0.40$ & $<0.40$ & $<0.40$ & $<0.40$ & $<0.40$ \\
\hline pp-DDT,DDE,DDD & $<0.02$ & $<0.02$ & $<0.02$ & $<0.02$ & $<0.02$ & $<0.02$ \\
\hline Dieldrin & $<0.01$ & $<0.01$ & $<0.01$ & $<0.01$ & $<0.01$ & $<0.01$ \\
\hline Endosulfan I,lI & $<0.01$ & $<0.01$ & $<0.01$ & $<0.01$ & $<0.01$ & $<0.01$ \\
\hline Endosulfan sulfate & $<0.04$ & $<0.04$ & $<0.04$ & $<0.04$ & $<0.04$ & 0.04 \\
\hline Endrin & $<0.01$ & $<0.01$ & $<0.01$ & $<0.01$ & $<0.01$ & $<0.01$ \\
\hline Endrin aldehyde & $<0.04$ & $<0.04$ & $<0.04$ & $<0.04$ & $<0.04$ & $<0.04$ \\
\hline Heptachlor & $<0.01$ & $<0.01$ & $<0.01$ & $<0.01$ & $<0.01$ & $<0.01$ \\
\hline Heptachlor epoxide & 1.39 & 0.62 & 0.82 & $<0.01$ & 0.53 & 0.59 \\
\hline Toxaphene & $<0.50$ & $<0.50$ & $<0.50$ & $<0.50$ & $<0.50$ & $<0.50$ \\
\hline alpha-BHC & $<0.01$ & 0.18 & $<0.01$ & $<0.01$ & $<0.01$ & $<0.01$ \\
\hline beta-BHC & $<0.01$ & $<0.01$ & $<0.01$ & $<0.01$ & $<0.01$ & $<0.01$ \\
\hline gamma-BHC & $<0.01$ & $<0.01$ & $<0.01$ & $<0.01$ & $<0.01$ & $<0.01$ \\
\hline Total BHC & $<0.01$ & 0.11 & 0.22 & $<0.01$ & $<0.01$ & $<0.01$ \\
\hline PCBs (ppb) & $<100$ & $<100$ & $<100$ & $<100$ & $<100$ & $<100$ \\
\hline
\end{tabular}


Appendix A Table 2 (cont.)

\begin{tabular}{|c|c|c|c|c|c|c|}
\hline PAHs (ppm) & $\mathrm{E}$ & $\mathrm{F}$ & G & $\mathrm{H}$ & I & $\bar{J}$ \\
\hline \multicolumn{7}{|l|}{ Low Molecular Weight } \\
\hline $\begin{array}{c}\text { Napthalene } \\
\text { Acenapthene } \\
\text { Acenapthylene } \\
\text { Fluorene } \\
\text { Phenanthrene } \\
\text { Anthracene }\end{array}$ & $\begin{array}{r}0.03 \\
<0.05 \\
<0.05 \\
<0.05 \\
0.07 \\
<0.05\end{array}$ & $\begin{array}{r}<0.02 \\
<0.02 \\
<0.02 \\
<0.02 \\
0.11 \\
0.03\end{array}$ & $\begin{array}{r}0.14 \\
<0.05 \\
<0.05 \\
0.08 \\
0.36 \\
0.08 \\
\end{array}$ & $\begin{array}{r}0.48 \\
0.26 \\
<0.05 \\
0.47 \\
1.07 \\
0.22\end{array}$ & $\begin{array}{r}0.06 \\
<0.06 \\
<0.06 \\
<0.06 \\
0.18 \\
<0.06 \\
\end{array}$ & $\begin{array}{r}0.05 \\
<0.03 \\
<0.03 \\
<0.03 \\
0.21 \\
0.06\end{array}$ \\
\hline \multicolumn{7}{|l|}{ High Molecular Weight } \\
\hline $\begin{array}{c}\text { Fluoranthene } \\
\text { Pyrene } \\
\text { Benzo(a)anthracene } \\
\text { Chrysene } \\
\text { Benzo(b)fluoranthene } \\
\text { Benzo(k)fluoranthene } \\
\text { Benzo(a)pyrene } \\
\text { Benzo(g,h,i)perylene } \\
\text { Dibenzo(a,h)anthracene } \\
\text { Indeno(1,2,3-cd)pyrene }\end{array}$ & $\begin{array}{r}0.16 \\
0.16 \\
0.06 \\
0.06 \\
<0.05 \\
<0.05 \\
<0.05 \\
<0.05 \\
<0.05 \\
<0.05\end{array}$ & $\begin{array}{r}0.54 \\
0.58 \\
0.39 \\
0.29 \\
0.29 \\
0.25 \\
0.27 \\
0.19 \\
<0.02 \\
0.31\end{array}$ & $\begin{array}{r}0.83 \\
0.78 \\
0.28 \\
0.38 \\
0.34 \\
0.32 \\
0.31 \\
0.30 \\
<0.05 \\
<0.05\end{array}$ & $\begin{array}{r}0.94 \\
0.93 \\
0.31 \\
0.30 \\
0.37 \\
0.35 \\
0.35 \\
0.29 \\
<0.05 \\
<0.05\end{array}$ & $\begin{array}{r}0.43 \\
0.43 \\
0.19 \\
0.19 \\
0.13 \\
0.13 \\
0.13 \\
<0.06 \\
<0.06 \\
<0.06\end{array}$ & $\begin{array}{r}0.35 \\
0.37 \\
0.15 \\
0.14 \\
0.16 \\
0.11 \\
0.13 \\
<0.03 \\
<0.03 \\
<0.03 \\
\end{array}$ \\
\hline
\end{tabular}




\section{Appendix A Table 3}

Sediment Chemistry Results (Dry Weight) for Gulf Oil,

New Haven Harbor 1993

\begin{tabular}{|c|c|c|c|c|c|c|c|}
\hline GULF OIL & $\overline{\mathrm{B} 1}$ & $\overline{\mathrm{B} 2 \mathrm{~A} / \mathrm{B}^{*}}$ & $\overline{\mathrm{B} 3}$ & $\overline{\mathrm{B} 4}$ & $\overline{\mathrm{B} 5}$ & $\overline{\mathrm{B} 6 \mathrm{~A} / \mathrm{B}^{*}}$ & $\overline{\mathrm{B} 7}$ \\
\hline \multicolumn{8}{|l|}{ GRAIN SIZE } \\
\hline \% Gravel & 0 & 0 & 0 & 0 & 0.2 & 0 & 0 \\
\hline$\%$ Sand & 52.5 & 32.4 & 58.4 & 61.5 & 59.6 & 47.5 & 53.8 \\
\hline$\%$ Silt/clay & 46.6 & 36.8 & 42.3 & 38.4 & 40.1 & 55.7 & 46.6 \\
\hline \% TOC & 5.3 & 3.2 & 4.2 & 3.7 & 4.8 & 3.9 & $\overline{3.5}$ \\
\hline \multicolumn{8}{|l|}{ METALS(ppm) } \\
\hline As & ND & $\overline{\mathrm{ND}}$ & ND & ND & ND & ND & ND \\
\hline $\mathrm{Cd}$ & 5.91 & 4.9 & 5.36 & 4.76 & 5.87 & 6.55 & 6.65 \\
\hline $\mathrm{Cr}$ & 12 & 87.3 & 91.4 & 84.8 & 94.8 & 117 & 123 \\
\hline $\mathrm{Cu}$ & 200 & 130 & 150 & 135 & 156 & 200 & 217 \\
\hline $\mathrm{Pb}$ & 140 & 95 & 110 & 100 & 120 & 142 & 158 \\
\hline $\mathrm{Hg}$ & ND & ND & ND & ND & ND & ND & ND \\
\hline $\mathrm{Ni}$ & 49.9 & 30.5 & 38.4 & 33.5 & 39 & 41.9 & 46.2 \\
\hline $\mathrm{Zn}$ & 350 & 200 & 200 & 190 & 265 & 264 & 276 \\
\hline \multicolumn{8}{|l|}{ PESTICIDES(ppm) } \\
\hline Aldrin & ND & ND & ND & ND & ND & ND & ND \\
\hline Chlordane & ND & ND & ND & ND & ND & ND & ND \\
\hline pp-DDT,DDE,DDD & ND & ND & ND & ND & ND & ND & ND \\
\hline Dieldrin & ND & ND & ND & ND & ND & ND & ND \\
\hline Endosulfan I,II & ND & ND & ND & ND & ND & ND & ND \\
\hline Endosulfan sulfate & ND & ND & ND & ND & ND & ND & ND \\
\hline Endrin & ND & ND & ND & ND & ND & ND & ND \\
\hline Endrin aldehyde & ND & ND & ND & ND & ND & ND & ND \\
\hline Heptachlor & ND & ND & ND & ND & ND & ND & ND \\
\hline Heptachlor epoxide & ND & ND & ND & ND & ND & ND & ND \\
\hline Hexachlorocyclohexane (total) & ND & ND & ND & ND & ND & ND & ND \\
\hline Methoxychlor & ND & ND & ND & ND & ND & ND & ND \\
\hline Toxaphene & $\mathrm{ND}$ & ND & ND & ND & ND & ND & ND \\
\hline PCBs (ppb) & 190 & 210 & 250 & 280 & 250 & 140 & 150 \\
\hline
\end{tabular}


Appendix A Table 3 (cont.)

\begin{tabular}{|c|c|c|c|c|c|c|c|}
\hline PAHs (ppm) & $\mathrm{B} 1$ & $\mathrm{~B} 2 \mathrm{~A} / \mathrm{B}^{*}$ & B3 & B4 & B5 & $\mathrm{B} 6 \mathrm{~A} / \mathrm{B}^{*}$ & B7 \\
\hline \multicolumn{8}{|l|}{ Low Molecular Weight } \\
\hline Napthalene & $\mathrm{ND}$ & $\mathrm{ND}$ & ND & ND & ND & ND & ND \\
\hline 1-Methylnapthalene & ND & ND & ND & ND & $\mathrm{ND}$ & $\mathrm{ND}$ & ND \\
\hline Biphenyl & ND & $\mathrm{ND}$ & ND & ND & ND & ND & ND \\
\hline 2,6-Dimethylnapthalene & $\mathrm{ND}$ & ND & ND & ND & ND & $\mathrm{ND}$ & ND \\
\hline Acenapthene & $\mathrm{ND}$ & $\mathrm{ND}$ & ND & ND & $\mathrm{ND}$ & ND & ND \\
\hline Acenapthylene & ND & ND & ND & ND & $\mathrm{ND}$ & ND & ND \\
\hline Fluorene & 2.78 & ND & ND & ND & ND & $\mathrm{ND}$ & ND \\
\hline Phenanthrene & ND & 0.2 & ND & 0.13 & 0.22 & 0.43 & ND \\
\hline 1-Methylphenanthrene & ND & ND & ND & ND & ND & $\mathrm{ND}$ & ND \\
\hline Anthracene & 0.15 & ND & 0.27 & 0.2 & 0.35 & 0.71 & ND \\
\hline \multicolumn{8}{|l|}{ High Molecular Weight } \\
\hline Fluoranthene & $\mathrm{ND}$ & 0.99 & 0.58 & 0.66 & 1.38 & 2.56 & 1.22 \\
\hline Pyrene & 2.49 & 0.89 & 0.54 & 0.6 & 1.09 & 2.09 & 0.99 \\
\hline Benzo(a)anthracene & 8.75 & 4.36 & 0.16 & 2.49 & 4.10 & 8.33 & 4.07 \\
\hline Chrysene & 1.47 & 0.73 & 0.4 & 0.44 & 0.70 & 1.41 & 0.72 \\
\hline Benzo(b)fluoranthene & 2.09 & 1.29 & 0.83 & 0.73 & 1.09 & 1.75 & 1.1 \\
\hline Benzo(k)fluoranthene & 1.97 & 1.22 & ND & 0.7 & ND & 0.12 & ND \\
\hline Benzo(a)pyrene & 2.79 & 0.56 & 0.43 & 0.27 & 0.63 & 0.78 & 0.54 \\
\hline Benzo(e)pyrene & ND & ND & ND & ND & ND & $\mathrm{ND}$ & ND \\
\hline Benzo(g,h,i)perylene & ND & ND & 0.96 & 0.53 & $\mathrm{ND}$ & ND & ND \\
\hline Dibenzo(a,h)anthracene & 0.54 & ND & ND & 0.29 & $\mathrm{ND}$ & 0.2 & ND \\
\hline Indeno(1,2,3-cd)pyrene & ND & ND & ND & 0.29 & ND & 0.28 & ND \\
\hline Perylene & ND & ND & ND & ND & ND & ND & ND \\
\hline
\end{tabular}

* Composites of two samples 


\section{Appendix A Table 4}

Sediment Chemistry Results (Dry Weight) for Northeast Petroleum, New Haven Harbor 1993

\begin{tabular}{|c|c|c|c|c|c|c|c|}
\hline NORTHEAST PETROLEUM & $\overline{\mathrm{T} 1}$ & $\mathrm{~T} 2$ & B1 & $\overline{\mathrm{B} 2}$ & B3 & $\overline{\mathrm{B} 3}$ & $\overline{\mathrm{B} 3}$ \\
\hline \multicolumn{8}{|l|}{$\overline{\text { GRAIN SIZE }}$} \\
\hline \%Gravel & 0.0 & 0.0 & 0.0 & 0.0 & 0.0 & 0.0 & 0.0 \\
\hline$\%$ Sand & 9.5 & 10.7 & 10.3 & 8.35 & 7.82 & 12.6 & 97.7 \\
\hline$\%$ Silt/clay & 90.54 & 89.3 & 89.7 & 91.65 & 92.18 & 87.4 & 2.3 \\
\hline \%TOC & 3.4 & 3.6 & 4.8 & $\overline{3.1}$ & 2.6 & 0.9 & 0.07 \\
\hline \multicolumn{8}{|l|}{ METALS (ppm) } \\
\hline As & 0.604 & 0.612 & 1.01 & 1.05 & 1.17 & 0.386 & 0.431 \\
\hline $\mathrm{Cd}$ & ND & $\mathrm{ND}$ & ND & 0.065 & 0.505 & ND & ND \\
\hline $\mathrm{Cr}$ & 71.4 & 61.2 & 71.3 & 92.8 & 128.0 & 5.56 & 32.0 \\
\hline $\mathrm{Cu}$ & 107.0 & 92.7 & 100.0 & 60.2 & 73.4 & 46.3 & 4.08 \\
\hline $\mathrm{Pb}$ & 69.9 & 61.0 & 75.0 & 77.3 & 122.0 & 10.7 & 29.0 \\
\hline $\mathrm{Hg}$ & 0.093 & 0.099 & 0.136 & 0.098 & 0.036 & 0.006 & 0.086 \\
\hline $\mathrm{Ni}$ & 18.7 & 19.9 & 25.1 & 24.1 & 32.4 & 6.3 & 10.9 \\
\hline $\mathrm{Zn}$ & 156.0 & 159.0 & 182.0 & 188.0 & 235.0 & 16.2 & 57.2 \\
\hline \multicolumn{8}{|l|}{ PESTICIDES (ppm) } \\
\hline Aldrin & ND & ND & ND & $\overline{\mathrm{ND}}$ & ND & ND & ND \\
\hline Chlordane & ND & ND & ND & ND & ND & ND & ND \\
\hline pp-DDT,DDE,DDD & ND & $\mathrm{ND}$ & ND & ND & ND & ND & ND \\
\hline Dieldrin & ND & $\mathrm{ND}$ & ND & ND & ND & ND & ND \\
\hline Endosulfan I,II & ND & ND & ND & ND & ND & ND & ND \\
\hline Endosulfan sulfate & ND & ND & ND & ND & ND & ND & $\mathrm{ND}$ \\
\hline Endrin & ND & $\mathrm{ND}$ & ND & ND & ND & ND & $\mathrm{ND}$ \\
\hline Endrin aldehyde & ND & ND & ND & ND & ND & ND & ND \\
\hline Heptachlor & $\mathrm{ND}$ & ND & ND & ND & ND & ND & ND \\
\hline Heptachlor epoxide & $\mathrm{ND}$ & $\mathrm{ND}$ & ND & ND & ND & ND & ND \\
\hline Hexachlorocyclohexane (total) & ND & $\mathrm{ND}$ & ND & ND & ND & ND & $\mathrm{ND}$ \\
\hline Methoxychlor & ND & $\mathrm{ND}$ & ND & ND & ND & ND & ND \\
\hline Toxaphene & ND & ND & ND & ND & ND & ND & $\mathrm{ND}$ \\
\hline PCBs (ppb) & ND & ND & ND & $\overline{\mathrm{ND}}$ & ND & ND & ND \\
\hline
\end{tabular}

ND $=$ Not Detected 
Appendix A Table 4 (cont.)

\begin{tabular}{|c|c|c|c|c|c|c|c|}
\hline$\overline{\text { PAHs (ppm) }}$ & TI & $\overline{\mathrm{T} 2}$ & $\overline{\mathrm{B} 1}$ & $\overline{\mathrm{B} 2}$ & $\overline{\mathrm{B} 3}$ & $\overline{\mathrm{B} 3}$ & $\overline{\mathrm{B} 3}$ \\
\hline \multicolumn{8}{|l|}{ Low Molecular Weight } \\
\hline Napthalene & ND & ND & $\mathrm{ND}$ & $\mathrm{ND}$ & ND & 0.06 & ND \\
\hline 1-Methylnapthalene & ND & $\mathrm{ND}$ & ND & ND & ND & ND & ND \\
\hline 2-Methylnapthalene & ND & $\mathrm{ND}$ & ND & ND & ND & ND & $\mathrm{ND}$ \\
\hline Biphenyl & ND & $\mathrm{ND}$ & ND & ND & ND & $\mathrm{ND}$ & ND \\
\hline 2,6-Dimethylnapthalene & ND & $\mathrm{ND}$ & ND & ND & ND & ND & $\mathrm{ND}$ \\
\hline Acenapthene & ND & 0.24 & ND & ND & ND & $\mathrm{ND}$ & ND \\
\hline Acenapthylene & ND & $\mathrm{ND}$ & ND & ND & 0.03 & ND & ND \\
\hline Fluorene & ND & 0.23 & ND & ND & $\mathrm{ND}$ & $\mathrm{ND}$ & $\mathrm{ND}$ \\
\hline Phenanthrene & ND & 0.94 & ND & ND & 0.06 & ND & $\mathrm{ND}$ \\
\hline 1-Methylphenanthrene & ND & $\mathrm{ND}$ & ND & ND & $\mathrm{ND}$ & ND & $\mathrm{ND}$ \\
\hline - Anthracene & $\mathrm{ND}$ & $\mathrm{ND}$ & ND & $\mathrm{ND}$ & 0.04 & $\mathrm{ND}$ & $\mathrm{ND}$ \\
\hline \multicolumn{8}{|l|}{ High Molecular Weight } \\
\hline Fluoranthene & 0.43 & 4.66 & $\mathrm{ND}$ & ND & 0.11 & 0.44 & ND \\
\hline Pyrene & 0.31 & 2.54 & ND & $\mathrm{ND}$ & ND & 0.26 & $\mathrm{ND}$ \\
\hline Benzo(a)anthracene & ND & 0.25 & ND & ND & 0.03 & ND & ND \\
\hline Chrysene & 0.14 & ND & ND & ND & $\mathrm{ND}$ & 0.14 & ND \\
\hline Benzo(b)fluoranthene & ND & 0.21 & ND & ND & 0.45 & 0.05 & ND \\
\hline Benzo(k)fluoranthene & ND & 0.22 & ND & ND & 0.58 & 0.07 & ND \\
\hline Benzo(a)pyrene & ND & 0.27 & ND & ND & $\mathrm{ND}$ & 0.1 & ND \\
\hline Benzo(e)pyrene & ND & $\mathrm{ND}$ & ND & ND & $\mathrm{ND}$ & ND & ND \\
\hline Benzo(g,h,i)perylene & ND & $\mathrm{ND}$ & ND & ND & $\mathrm{ND}$ & ND & ND \\
\hline Dibenzo(a,h)anthracene & ND & $\mathrm{ND}$ & ND & ND & $\mathrm{ND}$ & $\mathrm{ND}$ & $\mathrm{ND}$ \\
\hline Indeno(1,2,3-cd)pyrene & ND & ND & ND & ND & ND & $\mathrm{ND}$ & ND \\
\hline Perylene & $\mathrm{ND}$ & $\mathrm{ND}$ & ND & ND & $\mathrm{ND}$ & $\mathrm{ND}$ & $\mathrm{ND}$ \\
\hline
\end{tabular}

ND $=$ Not Detected 
Appendix A Table 4 (cont.)

\begin{tabular}{|c|c|c|c|c|c|c|c|}
\hline NORTHEAST PETROLEUM & $\overline{\mathrm{B} 4}$ & $\overline{\mathrm{B} 4}$ & $\overline{\mathrm{B} 5}$ & $\overline{\mathrm{B} 5}$ & $\overline{\mathrm{B} 6}$ & $\overline{\mathrm{B} 7}$ & $\overline{\bar{B} 8}$ \\
\hline \multicolumn{8}{|l|}{ GRAIN SIZE } \\
\hline \%Gravel & 0 & 0 & $\overline{0}$ & $\overline{0}$ & 0 & $\overline{0}$ & 1.67 \\
\hline$\%$ Sand & 11.4 & 6.82 & 7.43 & 10.4 & 11.2 & 69.7 & 74.5 \\
\hline \%Silt/clay & 88.6 & 93.18 & 92.57 & 89.6 & 88.8 & 26.7 & 21.6 \\
\hline \% TOC & 3.2 & 1.6 & 3.5 & 2 & 2.2 & 0.46 & 0.26 \\
\hline \multicolumn{8}{|l|}{$\overline{\text { METALS (ppm) }}$} \\
\hline As & 0.894 & 0.751 & 1.4 & 1.13 & 1.35 & NA & $\overline{\mathrm{NA}}$ \\
\hline $\mathrm{Cd}$ & ND & ND & 1.22 & 0.864 & ND & NA & NA \\
\hline $\mathrm{Cr}$ & 73.4 & 91.5 & 1.56 & 101 & 72.5 & NA & NA \\
\hline $\mathrm{Cu}$ & 130 & 54.2 & 98.4 & 64.7 & 88.1 & NA & NA \\
\hline $\mathrm{Pb}$ & 78.4 & 81 & 144 & 98.7 & 73.9 & NA & NA \\
\hline $\mathrm{Hg}$ & 0.136 & 0.183 & 0.203 & 0.109 & 0.086 & NA & NA \\
\hline $\mathrm{Ni}$ & 25.7 & 23.4 & 40.3 & 24.8 & 22.7 & NA & $\mathrm{NA}$ \\
\hline $\mathrm{Zn}$ & 166 & 306 & 919 & 543 & 149 & 4.22 & 7.62 \\
\hline \multicolumn{8}{|l|}{ PESTICIDES (ppm) } \\
\hline Aldrin & ND & ND & ND & ND & $\mathrm{ND}$ & ND & ND \\
\hline Chlordane & $\mathrm{ND}$ & ND & ND & ND & ND & ND & ND \\
\hline pp-DDT,DDE,DDD & $\mathrm{ND}$ & ND & ND & ND & ND & ND & ND \\
\hline Dieldrin & $\mathrm{ND}$ & $\mathrm{ND}$ & ND & ND & ND & ND & ND \\
\hline Endosulfan I,II & $\mathrm{ND}$ & $\mathrm{ND}$ & ND & ND & ND & ND & ND \\
\hline Endosulfan sulfate & $\mathrm{ND}$ & $\mathrm{ND}$ & ND & ND & ND & ND & ND \\
\hline Endrin & $\mathrm{ND}$ & $\mathrm{ND}$ & ND & ND & ND & ND & ND \\
\hline Endrin aldehyde & $\mathrm{ND}$ & $\mathrm{ND}$ & ND & ND & ND & ND & ND \\
\hline Heptachlor & $\mathrm{ND}$ & $\mathrm{ND}$ & ND & ND & $\mathrm{ND}$ & ND & ND \\
\hline Heptachlor epoxide & $\mathrm{ND}$ & ND & ND & ND & ND & ND & ND \\
\hline Hexachlorocyclohexane (total) & $\mathrm{ND}$ & $\mathrm{ND}$ & ND & ND & ND & ND & ND \\
\hline Methoxychlor & $\mathrm{ND}$ & ND & ND & ND & ND & ND & ND \\
\hline Toxaphene & ND & $\mathrm{ND}$ & ND & ND & ND & ND & ND \\
\hline$\overline{\mathrm{PCBS}(\mathrm{ppb})}$ & $\mathrm{ND}$ & ND & ND & $\overline{\mathrm{ND}}$ & $\mathrm{ND}$ & ND & $\overline{\mathrm{ND}}$ \\
\hline
\end{tabular}

ND $=$ Not Detected NA $=$ Not Given 
Appendix A Table 4 (cont.)

\begin{tabular}{|c|c|c|c|c|c|c|c|}
\hline$\overline{\text { PAHs (ppm) }}$ & $\overline{\mathrm{B} 4}$ & $\overline{\mathrm{B} 4}$ & $\overline{\mathrm{B} 5}$ & B5 & $\overline{86}$ & $\overline{\mathrm{B} 7}$ & $\overline{\mathrm{B} 8}$ \\
\hline \multicolumn{8}{|l|}{ Low Molecular Weight } \\
\hline Napthalene & 0.12 & 0.14 & 0.04 & 0.6 & $\overline{\mathrm{ND}}$ & ND & ND \\
\hline 1-Methylnapthalene & ND & ND & ND & ND & ND & ND & ND \\
\hline 2-Methylnapthalene & ND & ND & ND & ND & ND & ND & ND \\
\hline Biphenyl & ND & ND & ND & ND & ND & ND & ND \\
\hline 2,6-Dimethylnapthalene & ND & ND & ND & ND & ND & ND & ND \\
\hline Acenapthene & ND & ND & 0.14 & ND & ND & ND & ND \\
\hline Acenapthylene & ND & 0.09 & ND & ND & ND & ND & ND \\
\hline Fluorene & ND & 0.14 & ND & 0.08 & ND & ND & ND \\
\hline Phenanthrene & 0.09 & 0.28 & 0.13 & 0.07 & ND & ND & ND \\
\hline 1-Methylphenanthrene & ND & ND & ND & ND & ND & ND & ND \\
\hline Anthracene & ND & 0.06 & 0.46 & ND & ND & ND & ND \\
\hline \multicolumn{8}{|l|}{ High Molecular Weight } \\
\hline Fluoranthene & 1.6 & 3.13 & 2.3 & 1.27 & 0.9 & ND & ND \\
\hline Pyrene & 1 & 2.3 & 1.46 & 0.78 & 0.55 & ND & ND \\
\hline Benzo(a)anthracene & 0.13 & 0.24 & 0.14 & 0.08 & 0.09 & ND & ND \\
\hline Chrysene & ND & 0.05 & ND & ND & ND & ND & ND \\
\hline Benzo(b)fluoranthene & 0.17 & 0.38 & 0.12 & 0.13 & 0.12 & ND & ND \\
\hline Benzo(k)fluoranthene & 0.24 & 0.52 & 0.21 & 0.17 & 0.15 & ND & ND \\
\hline Benzo(a)pyrene & 0.31 & 0.49 & ND & 0.22 & 0.15 & ND & ND \\
\hline Benzo(e)pyrene & ND & ND & ND & ND & ND & ND & ND \\
\hline Benzo(g,h,i)perylene & ND & ND & ND & ND & ND & ND & ND \\
\hline Dibenzo(a,h)anthracene & ND & 0.05 & ND & ND & ND & ND & ND \\
\hline Indeno(1,2,3-cd)pyrene & ND & ND & ND & ND & ND & ND & ND \\
\hline Perylene & ND & ND & ND & ND & ND & ND & ND \\
\hline
\end{tabular}

$\overline{\mathrm{ND}}=$ Not Detected 


\section{Appendix A Table 5}

Sediment Chemistry Results (Dry Weight) for the New Haven Terminal, New Haven Harbor 1993

\begin{tabular}{|c|c|c|c|c|c|}
\hline NEW HAVEN TERMINAL & B1 & B2 & B3 & B5 & B6 \\
\hline \multicolumn{6}{|l|}{ GRAIN SIZE } \\
\hline$\%$ Gravel & 23.1 & 13.8 & 2.13 & 13.4 & 3.58 \\
\hline$\%$ Sand & 57.0 & 63.8 & 62.4 & 60.4 & 66.5 \\
\hline \%Silt/clay & 20.6 & 18.5 & 32.1 & 26.9 & 26.3 \\
\hline$\%$ TOC & 2.4 & 1.6 & 1.4 & 1.2 & 3.3 \\
\hline \multicolumn{6}{|l|}{ METALS (ppm) } \\
\hline As & $\mathrm{ND}$ & ND & ND & ND & ND \\
\hline $\mathrm{Cd}$ & $\mathrm{ND}$ & ND & ND & $\mathrm{ND}$ & ND \\
\hline $\mathrm{Cr}$ & 50.9 & 30.4 & 38 & 46.8 & 77.3 \\
\hline $\mathrm{Cu}$ & 80 & 43.1 & 57.7 & 63.5 & 105 \\
\hline $\mathrm{Pb}$ & 69.6 & 32.4 & 49.8 & 59.5 & 90.3 \\
\hline $\mathrm{Hg}$ & $\mathrm{ND}$ & ND & ND & ND & ND \\
\hline $\mathrm{Ni}$ & 21.6 & 11.7 & 15.8 & 19.9 & 25.4 \\
\hline $\mathrm{Zn}$ & 139 & 92.6 & 98.3 & 121 & 181 \\
\hline \multicolumn{6}{|l|}{ PESTICIDES (ppm) } \\
\hline Aldrin & ND & ND & ND & $\mathrm{ND}$ & ND \\
\hline Chlordane & ND & ND & ND & $\mathrm{ND}$ & ND \\
\hline pp-DDT,DDE,DDD & ND & ND & ND & $\mathrm{ND}$ & ND \\
\hline Dieldrin & ND & ND & ND & ND & ND \\
\hline Endosulfan I,II & $\mathrm{ND}$ & ND & ND & $\mathrm{ND}$ & ND \\
\hline Endosulfan sulfate & $\mathrm{ND}$ & $\mathrm{ND}$ & ND & $\mathrm{ND}$ & ND \\
\hline Endrin & ND & ND & ND & $\mathrm{ND}$ & ND \\
\hline Endrin aldehyde & $\mathrm{ND}$ & ND & ND & $\mathrm{ND}$ & ND \\
\hline Heptachlor & $\mathrm{ND}$ & $\mathrm{ND}$ & ND & $\mathrm{ND}$ & ND \\
\hline Heptachlor epoxide & $\mathrm{ND}$ & ND & ND & $\mathrm{ND}$ & ND \\
\hline Hexachlorocyclohexane (total) & $\mathrm{ND}$ & $\mathrm{ND}$ & ND & $\mathrm{ND}$ & ND \\
\hline Methoxychlor & $\mathrm{ND}$ & $\mathrm{ND}$ & ND & $\mathrm{ND}$ & ND \\
\hline Toxaphene & $\mathrm{ND}$ & $\mathrm{ND}$ & ND & $\mathrm{ND}$ & ND \\
\hline PCBs (ppb) & ND & $\mathrm{ND}$ & ND & $\mathrm{ND}$ & ND \\
\hline
\end{tabular}


Appendix A Table 5 (cont.)

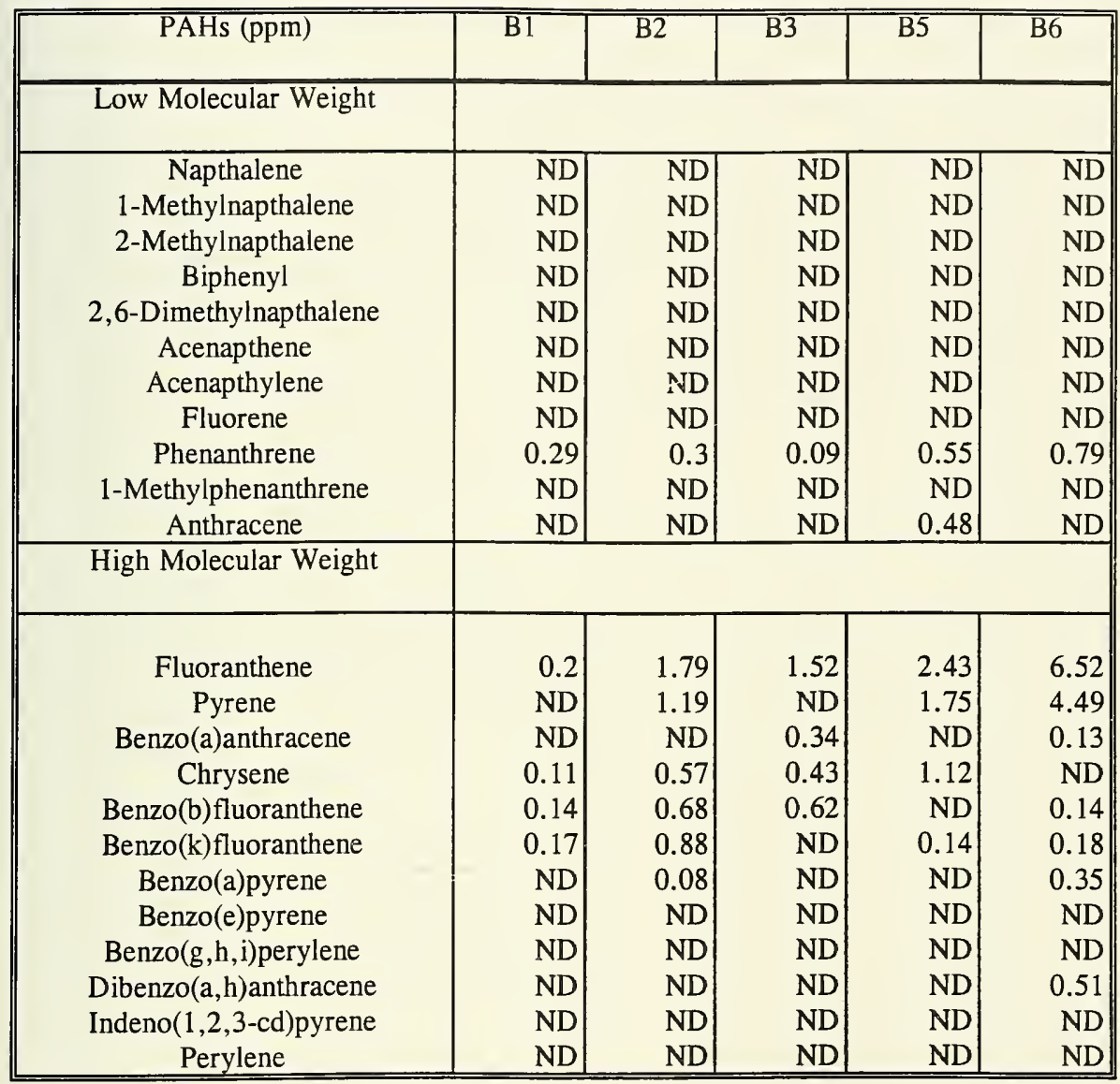




\section{Appendix A Table 6}

Sediment Chemistry Results (Dry Weight) for Mobil Oil, New Haven Harbor 1993

\begin{tabular}{|c|c|c|c|}
\hline$\overline{\text { MOBIL OIL }}$ & $\overline{\overline{\mathrm{B} 1}}$ & $\overline{\mathrm{B} 2}$ & $\overline{\mathrm{B} 3}$ \\
\hline \multicolumn{4}{|l|}{ GRAIN SIZE } \\
\hline$\%$ Gravel & 3.89 & 28.3 & 14.5 \\
\hline$\%$ Sand & 81.9 & 66.4 & 82.0 \\
\hline$\%$ Silt/clay & 14.2 & 5.5 & 3.68 \\
\hline$\%$ TOC & 4.9 & 3.5 & 0.65 \\
\hline \multicolumn{4}{|l|}{ METALS (ppm) } \\
\hline As & ND & ND & ND \\
\hline $\mathrm{Cd}$ & 1.25 & ND & ND \\
\hline $\mathrm{Cr}$ & 10.7 & 7.09 & 2.18 \\
\hline $\mathrm{Cu}$ & 18.7 & 0.944 & 2.24 \\
\hline $\mathrm{Pb}$ & 38.4 & 21.8 & 5.97 \\
\hline $\mathrm{Hg}$ & $\mathrm{ND}$ & $\mathrm{ND}$ & ND \\
\hline $\mathrm{Ni}$ & 7.83 & 4.8 & 2.66 \\
\hline $\mathrm{Zn}$ & 87.5 & 58.3 & 12.3 \\
\hline \multicolumn{4}{|l|}{ PESTICIDES (ppm) } \\
\hline Aldrin & ND & ND & $\overline{\mathrm{ND}}$ \\
\hline Chlordane & ND & ND & ND \\
\hline pp-DDT,DDE,DDD & $\mathrm{ND}$ & $\mathrm{ND}$ & ND \\
\hline Dieldrin & $\mathrm{ND}$ & $\mathrm{ND}$ & ND \\
\hline Endosulfan I,II & ND & $\mathrm{ND}$ & ND \\
\hline Endosulfan sulfate & $\mathrm{ND}$ & $\mathrm{ND}$ & ND \\
\hline Endrin & $\mathrm{ND}$ & ND & ND \\
\hline Endrin aldehyde & $\mathrm{ND}$ & ND & ND \\
\hline Heptachlor & $\mathrm{ND}$ & $\mathrm{ND}$ & ND \\
\hline Heptachlor epoxide & $\mathrm{ND}$ & $\mathrm{ND}$ & ND \\
\hline Hexachlorocyclohexane (total) & ND & $\mathrm{ND}$ & ND \\
\hline Methoxychlor & ND & $\mathrm{ND}$ & ND \\
\hline Toxaphene & ND & ND & ND \\
\hline PCBs (ppb) & 56 & 23 & ND \\
\hline
\end{tabular}


Appendix A Table 6 (cont.)

\begin{tabular}{|c|c|c|c|}
\hline PAHs (ppm) & B1 & B2 & B3 \\
\hline \multicolumn{4}{|l|}{ Low Molecular Weight } \\
\hline Napthalene & $\mathrm{ND}$ & ND & ND \\
\hline 1-Methylnapthalene & $\mathrm{ND}$ & ND & ND \\
\hline 2-Methylnapthalene & ND & ND & ND \\
\hline Biphenyl & $\mathrm{ND}$ & ND & ND \\
\hline 2,6-Dimethylnapthalene & ND & ND & ND \\
\hline Acenapthene & 0.42 & ND & ND \\
\hline Acenapthylene & 0.40 & 0.11 & ND \\
\hline Fluorene & 0.24 & ND & ND \\
\hline Phenanthrene & 0.74 & 0.24 & ND \\
\hline 1-Methylphenanthrene & ND & ND & ND \\
\hline Anthracene & 5.39 & 1.66 & ND \\
\hline \multicolumn{4}{|l|}{ High Molecular Weight } \\
\hline Fluoranthene & 1.86 & 1.44 & 0.05 \\
\hline Pyrene & 11.20 & 7.02 & 0.23 \\
\hline Benzo(a)anthracene & 0.65 & 4.79 & ND \\
\hline Chrysene & 1.61 & 0.68 & 0.03 \\
\hline Benzo(b)fluoranthene & 11.40 & 5.05 & 0.44 \\
\hline Benzo(k)fluoranthene & 1.37 & 0.56 & 0.56 \\
\hline Benzo(a)pyrene & 1.57 & 0.54 & 0.04 \\
\hline Benzo(e)pyrene & ND & ND & ND \\
\hline Benzo(g,h,i)perylene & 4.88 & 0.60 & 0.05 \\
\hline Dibenzo(a,h)anthracene & 2.47 & 1.04 & ND \\
\hline Indeno(1,2,3-cd)pyrene & ND & ND & ND \\
\hline Perylene & ND & ND & ND \\
\hline
\end{tabular}




\section{Appendix A Table 7}

Sediment Chemistry Results (Dry Weight) for Wyatt Incorporated, New Haven Harbor 1993

\begin{tabular}{|c|c|c|c|c|c|c|c|c|}
\hline \multirow[t]{2}{*}{ WYATT INCORPORATED } & B11 & B2 & B3 & B4) & $\mathrm{B} 4-\mathrm{A}$ & B5 & B6 & A1 \\
\hline & \multicolumn{3}{|c|}{ Arco berth } & \multicolumn{4}{|c|}{ Pink Tank berth } & \\
\hline \% Gravel & 12.7 & 8.98 & 18.4 & 11.3 & 0.0 & 3.43 & 0.5 & 0.0 \\
\hline$\%$ Sand & 67.6 & 70.2 & 56.3 & 72.6 & 69.5 & 68.3 & 87.1 & 34.1 \\
\hline$\%$ Silt/clay & 19.3 & 21.6 & 26.9 & 16.9 & 30.8 & 28.3 & 12.3 & 65.9 \\
\hline \% TOC & 3.8 & 3.4 & 4.8 & 2.0 & 3.9 & 3.1 & 0.64 & $\overline{4.3}$ \\
\hline \multicolumn{9}{|l|}{ METALS (ppm) } \\
\hline As & ND & ND & ND & ND & ND & ND & ND & $\mathrm{ND}$ \\
\hline $\mathrm{Cd}$ & $\mathrm{ND}$ & ND & 2.54 & 2.18 & 3.51 & 2.87 & 0.596 & 1.2 \\
\hline $\mathrm{Cr}_{\mathrm{r}}$ & 89.1 & 44.8 & 87.0 & 64.7 & 101.0 & 77.2 & 23.5 & 10.9 \\
\hline $\mathrm{Cu}$ & 148.0 & 67.0 & 144.0 & 190.3 & 206.0 & 171.0 & 68.6 & ND \\
\hline $\mathrm{Pb}$ & 168.0 & 59.3 & 105.0 & 113.0 & 131.0 & 106.0 & 4.48 & 24.4 \\
\hline $\mathrm{Hg}$ & ND & ND & ND & ND & ND & ND & ND & ND \\
\hline $\mathrm{Ni}$ & 45.4 & 21.1 & 26.5 & 19.8 & 29.9 & 25.1 & 8.46 & 8.19 \\
\hline $\mathrm{Zn}$ & $\mathrm{ND}$ & 139.0 & 214.0 & 149.0 & 265.0 & 213.0 & 82.8 & 61.9 \\
\hline PESTICIDES (ppm) & & & & & - & & & \\
\hline Aldrin & ND & ND & ND & $\mathrm{ND}$ & ND & ND & ND & ND \\
\hline Chlordane & ND & ND & ND & ND & ND & ND & ND & ND \\
\hline pp-DDT,DDE,DDD & $\mathrm{ND}$ & ND & ND & ND & $\mathrm{ND}$ & ND & ND & ND \\
\hline Dieldrin & ND & ND & ND & ND & ND & ND & ND & ND \\
\hline Endosulfan 1,Il & ND & ND & ND & ND & ND & ND & ND & ND \\
\hline Endosulfan sulfate & ND & ND & ND & ND & ND & ND & ND & ND \\
\hline Endrin & ND & ND & ND & ND & ND & ND & ND & ND \\
\hline Endrin aldehyde & ND & ND & ND & ND & ND & ND & ND & ND \\
\hline Heptachlor & ND & ND & ND & ND & ND & ND & ND & ND \\
\hline Heptachlor epoxide & ND & ND & ND & ND & ND & ND & ND & ND \\
\hline Hexachlorocyclohexane (total) & ND & ND & ND & ND & ND & ND & ND & ND \\
\hline Methoxychlor & ND & ND & ND & ND & ND & ND & ND & ND \\
\hline Toxaphene & ND & ND & ND & ND & ND & ND & ND & ND \\
\hline PCBs (ppb) & 25 & 22 & 27 & 53 & 68 & 59 & 47 & 49 \\
\hline
\end{tabular}


Appendix A Table 7 (cont.)

\begin{tabular}{|c|c|c|c|c|c|c|c|c|}
\hline \multirow[t]{2}{*}{ PAHs (ppm) } & B1I & B21 & $\overline{\mathrm{B} 3}$ & B4 & B4-A & $\mathrm{B5}$ & B6] & $\mathrm{A} 1$ \\
\hline & Arco ber & & & \multicolumn{3}{|c|}{ Pink Tank berth } & & \\
\hline \multicolumn{9}{|l|}{ Low Molecular Weight } \\
\hline Napthalene & ND & ND & $\overline{\text { ND }}$ & ND & 0.41 & ND & ND & ND \\
\hline 1-Methylnapthalene & ND & ND & ND & ND & ND & ND & ND & ND \\
\hline Biphenyl & ND & ND & ND & ND & ND & ND & ND & ND \\
\hline 2,6-Dimethylnapthalene & ND & ND & ND & ND & ND & ND & ND & ND \\
\hline Acenapthene & ND & ND & ND & ND & ND & ND & ND & ND \\
\hline Acenapthylene & ND & ND & ND & ND & ND & ND & ND & ND \\
\hline Fluorene & ND & ND & ND & ND & ND & ND & ND & ND \\
\hline Phenanthrene & ND & 0.11 & 0.18 & 0.30 & 0.80 & 0.53 & ND & 0.16 \\
\hline 1-Methylphenanthrene & ND & ND & ND & ND & ND & ND & ND & ND \\
\hline Anthracene & $\mathrm{ND}$ & ND & 0.19 & ND & 0.07 & ND & ND & 0.06 \\
\hline \multicolumn{9}{|l|}{ High Molecular Weight } \\
\hline Fluoranthene & 1.31 & 0.54 & 1.09 & 2.87 & 8.70 & 3.22 & 1.44 & 1.35 \\
\hline Pyrene & ND & 0.51 & 0.97 & 2.51 & 6.95 & 2.69 & 1.21 & 6.51 \\
\hline Benzo(a)anthracene & ND & ND & 0.51 & 0.14 & 0.17 & 0.13 & 0.07 & 5.37 \\
\hline Chrysene & 1.44 & 0.34 & 0.52 & 1.68 & 2.88 & 2.29 & 0.97 & 0.77 \\
\hline Benzo(b)fluoranthene & 2.88 & 0.88 & 2.01 & 2.79 & 2.36 & 4.34 & 1.73 & 7.45 \\
\hline Benzo(k)fluoranthene & 3.71 & 0.08 & 2.58 & 0.29 & 0.17 & 0.35 & 0.18 & 0.56 \\
\hline Benzo(a)pyrene & ND & $\mathrm{ND}$ & 0.21 & 0.40 & 0.60 & 0.48 & 0.29 & 0.65 \\
\hline Benzo(e)pyrene & ND & $\mathrm{ND}$ & ND & ND & 0.30 & ND & ND & ND \\
\hline Benzo(g,h,i)perylene & ND & ND & ND & 0.31 & ND & 0.72 & 0.07 & 2.10 \\
\hline Dibenzo(a,h)anthracene & ND & ND & 0.43 & 0.54 & 0.84 & 0.70 & 0.34 & 0.87 \\
\hline Indeno(1,2,3-cd)pyrene & ND & ND & ND & ND & ND & ND & ND & ND \\
\hline Perylene & ND & ND & ND & ND & ND & ND & ND & ND \\
\hline
\end{tabular}





\section{APPENDIX B}

Disposal and Capping Operations 



\section{Appendix B Disposal and Capping Operations}

Appendix B Table 1. Summary of Disposal Operations of Contaminated Sediments Dredged from New Haven Harbor, October 1993 to January 1994 (Source: Great Lakes Dredging Company)

Appendix B Table 2. Summary of Capping Operations at the NHAV93 Mound, November 1993 to February 1994 (Source: Great Lakes Dredging Company) 


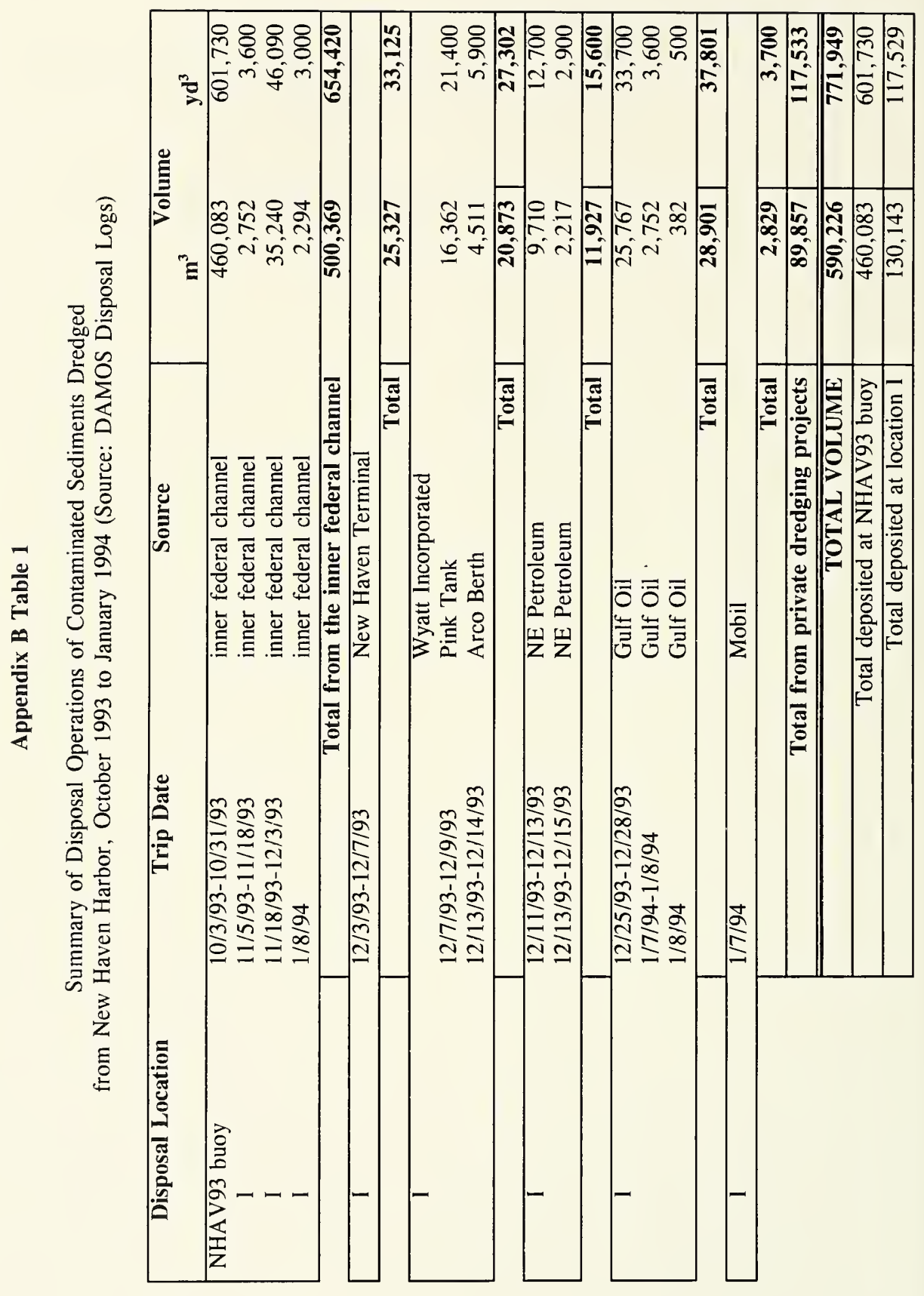




\begin{tabular}{|c|c|c|c|c|c|c|c|c|c|c|c|}
\hline \multirow{10}{*}{ 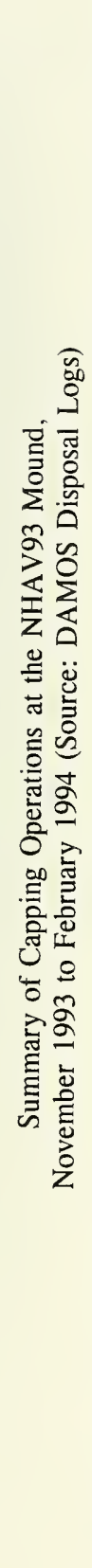 } & 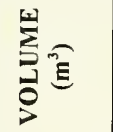 & $\begin{array}{l}0 \\
\overrightarrow{0} \\
m\end{array}$ & $\stackrel{\vec{m}}{\mathrm{~m}}$ & $\begin{array}{l}\vec{b} \\
0 \\
\text { ते }\end{array}$ & $\begin{array}{l}\frac{0}{n} \\
-5 \\
m\end{array}$ & $\begin{array}{l}\text { ले } \\
\text { हे }\end{array}$ & $\begin{array}{l}\stackrel{0}{m} \\
=\end{array}$ & $\begin{array}{l}\bar{\ddagger} \\
\bar{f} \\
\text { of }\end{array}$ & $\begin{array}{l}q \\
\dot{a} \\
\stackrel{0}{a}\end{array}$ & $\begin{array}{l}\tilde{o} \\
\stackrel{n}{2}\end{array}$ & 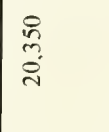 \\
\hline & 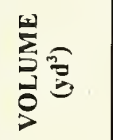 & $\begin{array}{l}\infty \\
\stackrel{\infty}{q} \\
q\end{array}$ & 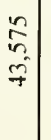 & $\begin{array}{c}8 \\
\vdots \\
\infty \\
\infty \\
0\end{array}$ & $\begin{array}{l}0 \\
+ \\
\text { के }\end{array}$ & $\begin{array}{l}\overrightarrow{8} \\
\text { : } \\
\text { in }\end{array}$ & 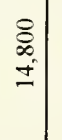 & $\begin{array}{l}8 \\
8 \\
8\end{array}$ & $\begin{array}{l}\stackrel{2}{2} \\
\underset{ \pm}{2}\end{array}$ & $\begin{array}{l}\text { 怘 } \\
\underline{\infty}\end{array}$ & $\begin{array}{l}\frac{n}{6} \\
\substack{0 \\
0}\end{array}$ \\
\hline & 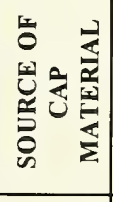 & 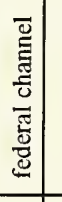 & 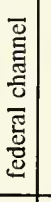 & 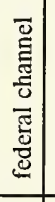 & 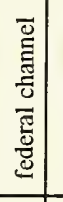 & 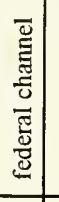 & 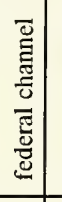 & 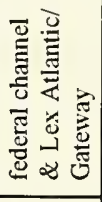 & 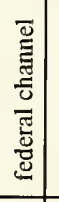 & 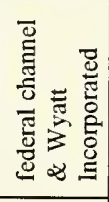 & 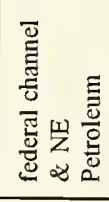 \\
\hline & 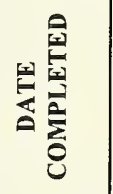 & $\stackrel{\substack{\hat{\infty} \\
ٍ}}{=}$ & 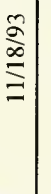 & $\begin{array}{l}\stackrel{2}{2} \\
\stackrel{\infty}{\Xi} \\
\vdots\end{array}$ & $\stackrel{\substack{\alpha \\
\infty}}{\Xi}$ & $\stackrel{\substack{\infty \\
\Xi}}{\Xi}$ & 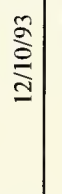 & 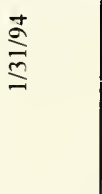 & 竞 & 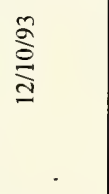 & 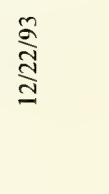 \\
\hline & 起畩 & 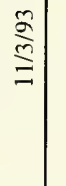 & 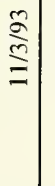 & $\stackrel{\substack{\mathcal{N} \\
ٍ}}{=}$ & 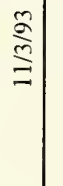 & 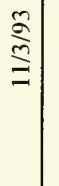 & $\stackrel{\substack{\mathcal{\infty} \\
\stackrel{\infty}{\Xi}}}{\stackrel{2}{2}}$ & $\stackrel{\substack{\alpha \\
ٍ \infty}}{=}$ & $\begin{array}{l}\stackrel{0}{2} \\
\stackrel{\infty}{\Xi} \\
=\end{array}$ & $\stackrel{\substack{\infty \\
ٍ}}{\stackrel{\infty}{\Xi}}$ & $\stackrel{\substack{\infty \\
ٍ}}{\leftrightarrows}$ \\
\hline & 㦴 & $\begin{array}{c}\tilde{q} \\
\tilde{w} \\
i\end{array}$ & $\begin{array}{c}\stackrel{m}{m} \\
\stackrel{m}{m}\end{array}$ & $\begin{array}{l}2 \\
m \\
m \\
\tilde{n}\end{array}$ & $\begin{array}{l}m \\
i \\
i\end{array}$ & $\begin{array}{l}\approx \\
\tilde{n} \\
\tilde{n}\end{array}$ & $\begin{array}{l}\overrightarrow{7} \\
\stackrel{n}{n}\end{array}$ & 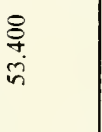 & $\begin{array}{l}\approx \\
\tilde{n} \\
\tilde{n}\end{array}$ & 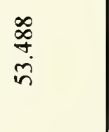 & 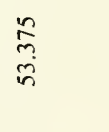 \\
\hline & בֵ & $\approx$ & $\approx$ & $\approx$ & $\approx$ & ה & $\approx$ & $\approx$ & $\approx$ & $\approx$ & $\approx$ \\
\hline & 0 & 壱 & 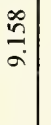 & $\begin{array}{c}\infty \\
\stackrel{\infty}{\sigma} \\
\sigma\end{array}$ & 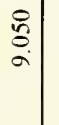 & $\Xi$ & $\frac{8}{2}$ & $\frac{8}{\circ}$ & \begin{tabular}{l}
7 \\
\multirow{a}{a}{} \\
$\sigma$
\end{tabular} & $\stackrel{\tilde{\sigma}}{\sigma}$ & $\stackrel{8}{\circ}$ \\
\hline & $\stackrel{5}{3}$ & $F$ & $\bar{F}$ & $\mp$ & $\mp$ & $F$ & $\bar{F}$ & $\bar{F}$ & $F$ & $F$ & $F$ \\
\hline & 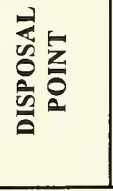 & $\begin{array}{l}\text { चै } \\
⿱ 亠 䒑 \\
\end{array}$ & |ֶّ & $\begin{array}{l}\text { Ũँ } \\
\text { Un }\end{array}$ & $\begin{array}{l}\text { गे } \\
\grave{i}\end{array}$ & 胥 & 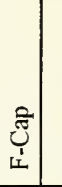 & 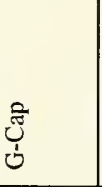 & 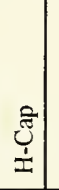 & త్ల & 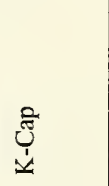 \\
\hline
\end{tabular}




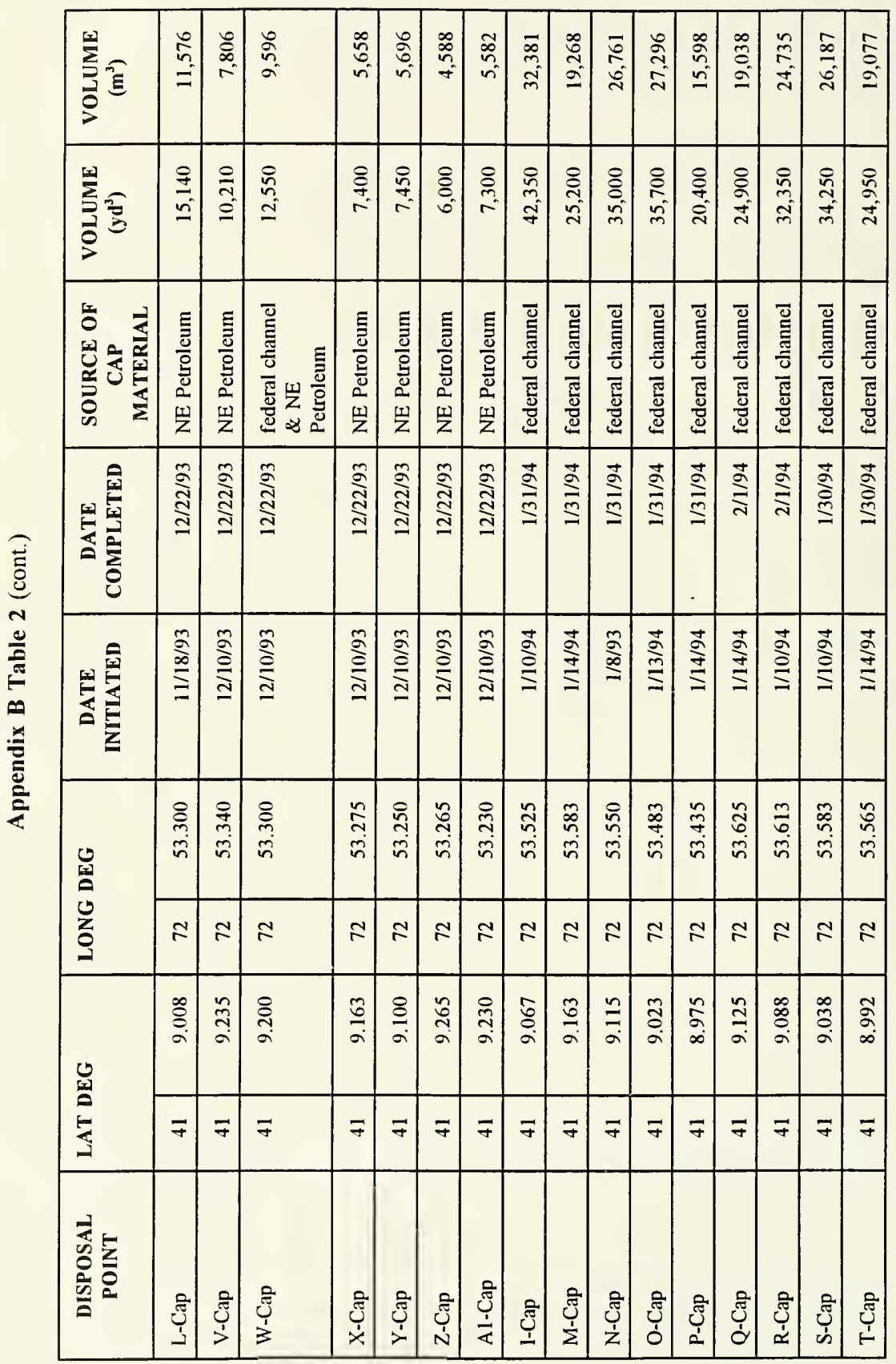




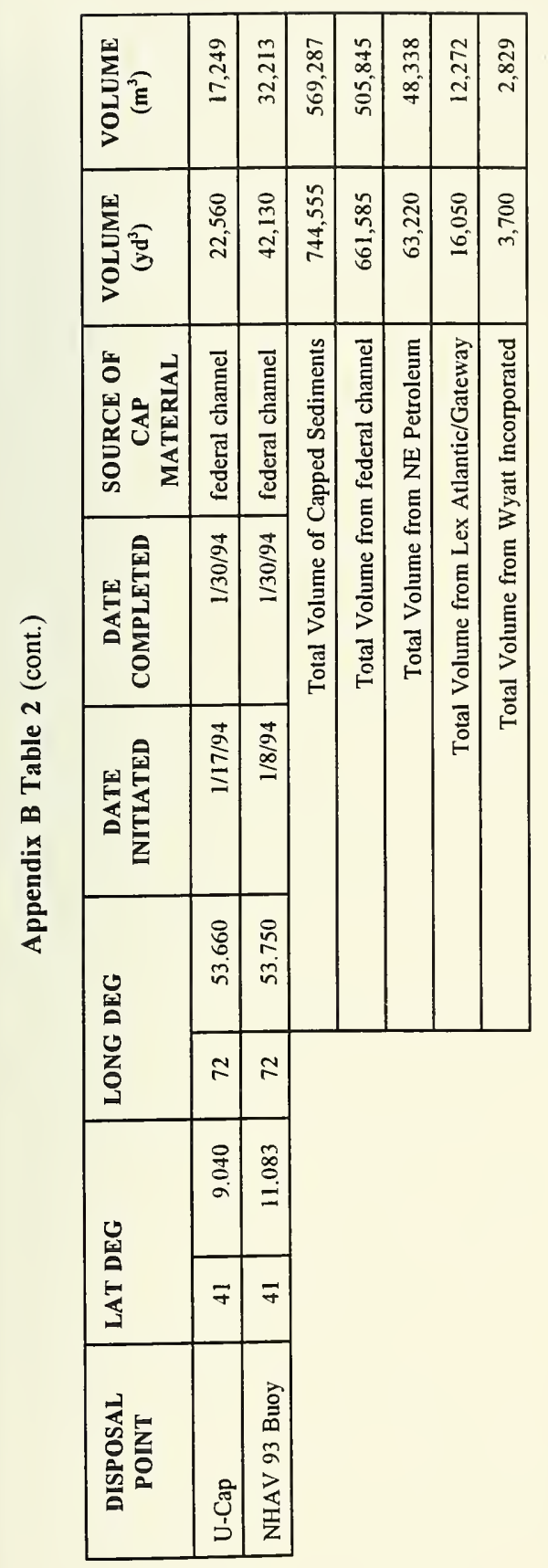



APPENDIX C

REMOTS ${ }^{\circledR}$ Sediment-Profile Surveys 



\section{Appendix C REMOTS ${ }^{\circledR}$ Sediment-Profile Surveys}

Appendix C Table 1. Station Locations and Results of the REMOTS ${ }^{\circledR}$ Baseline Survey Conducted in September 1993

Appendix C Table 2. $\quad$ Dredged Material Thickness from REMOTS ${ }^{\circledR}$ Precap Survey (34 November 1993)

Appendix C Table 3. Station Locations and Results of the REMOTS ${ }^{\circledR}$ Postdisposal Survey Conducted 4 November 1993 


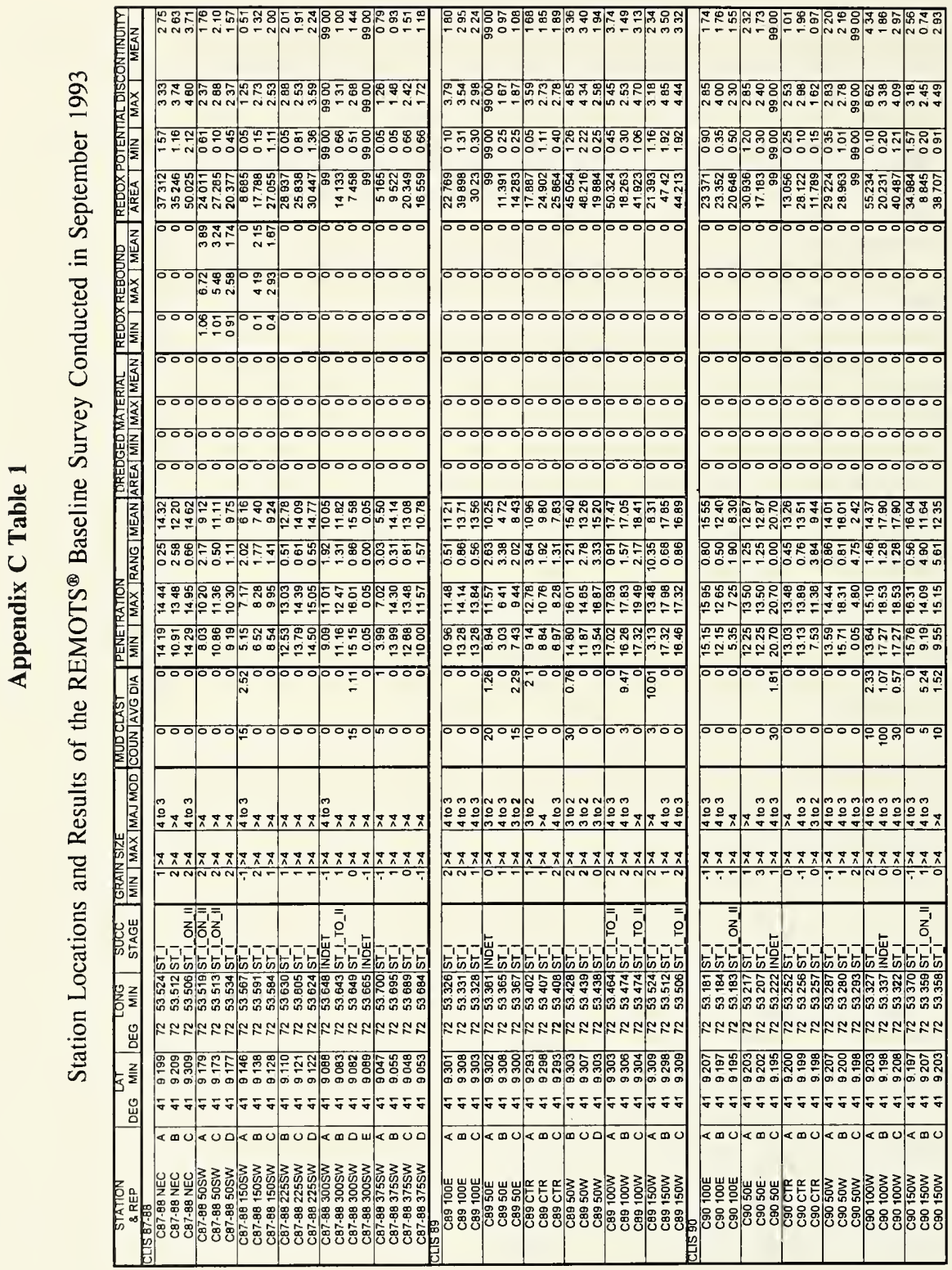




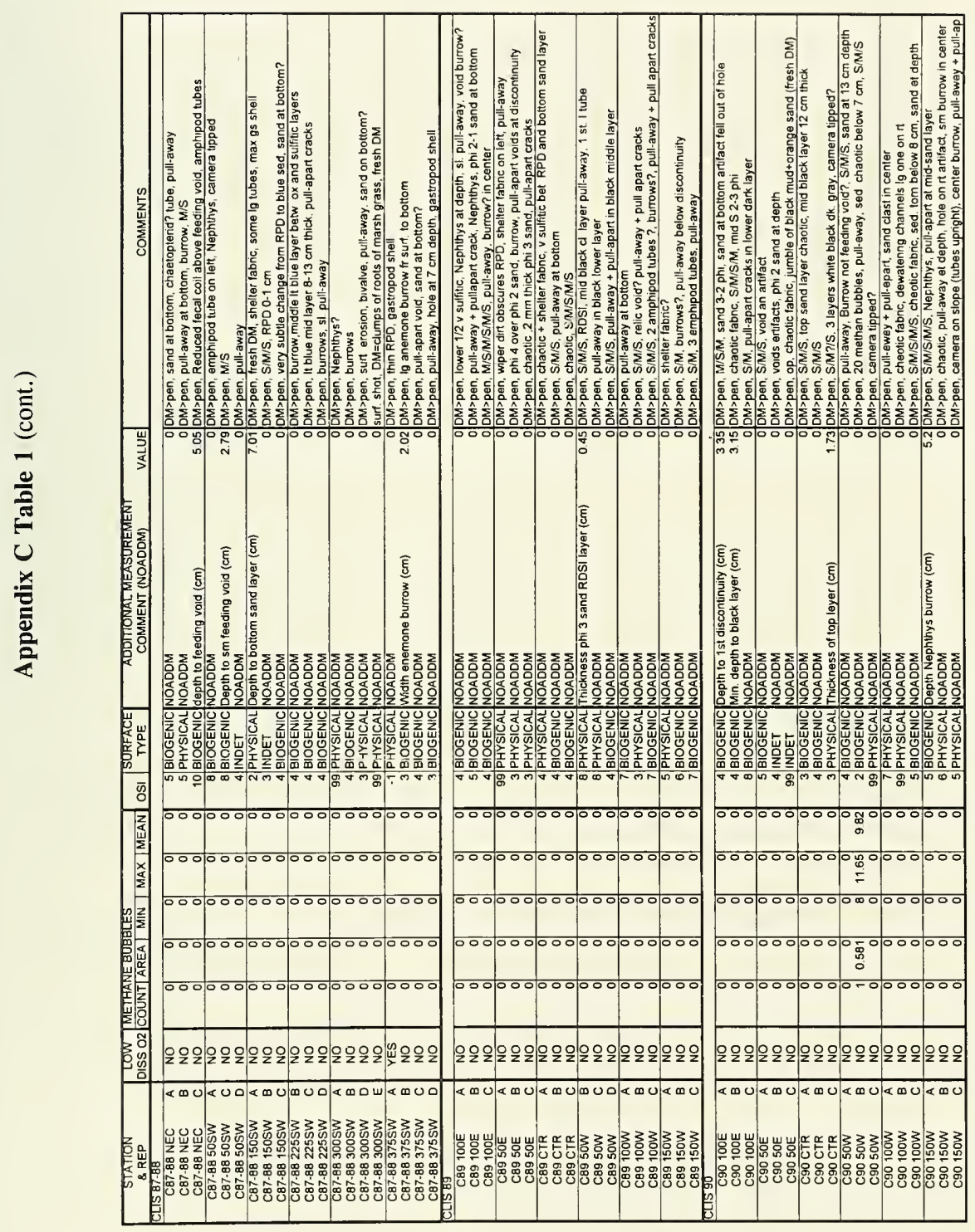




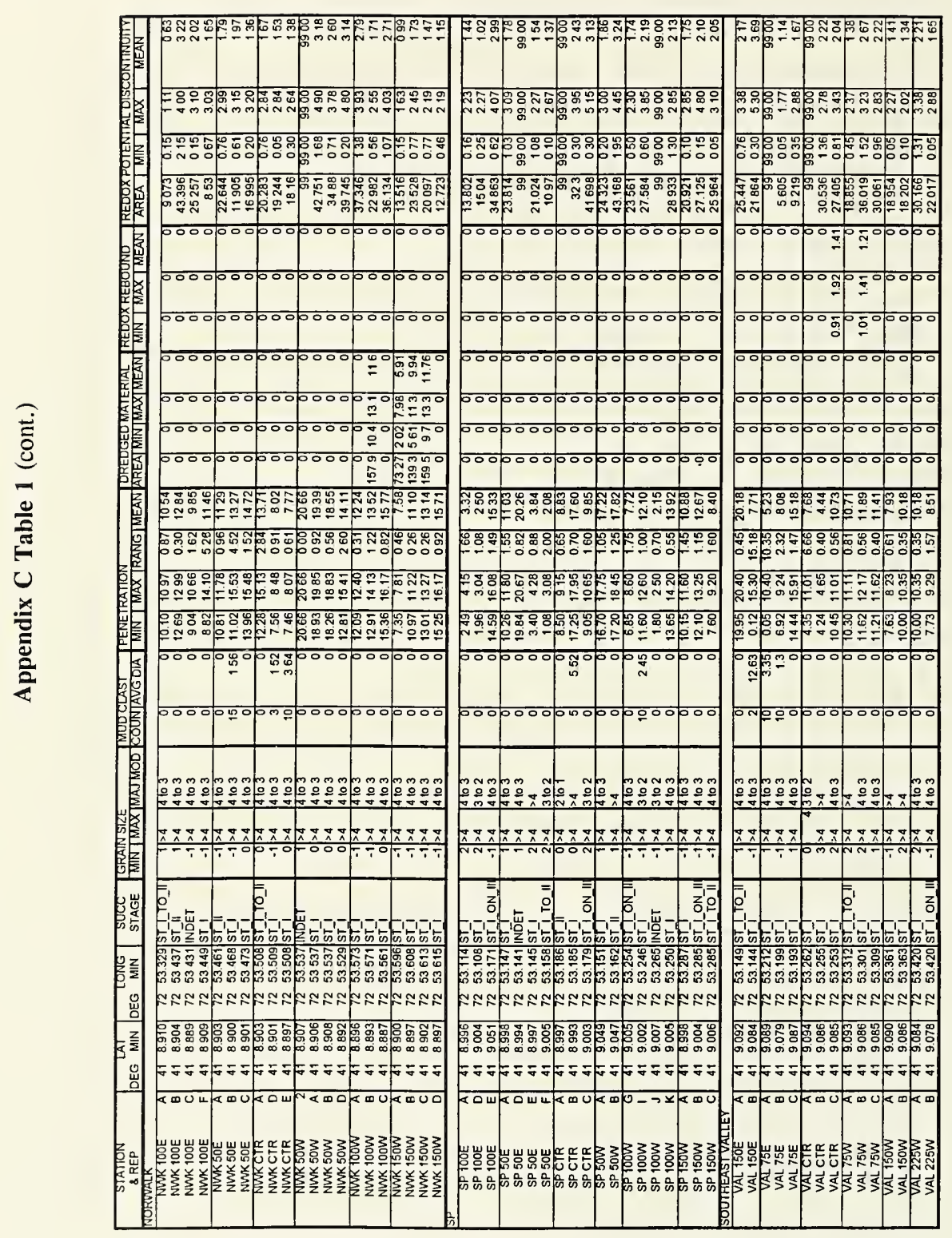




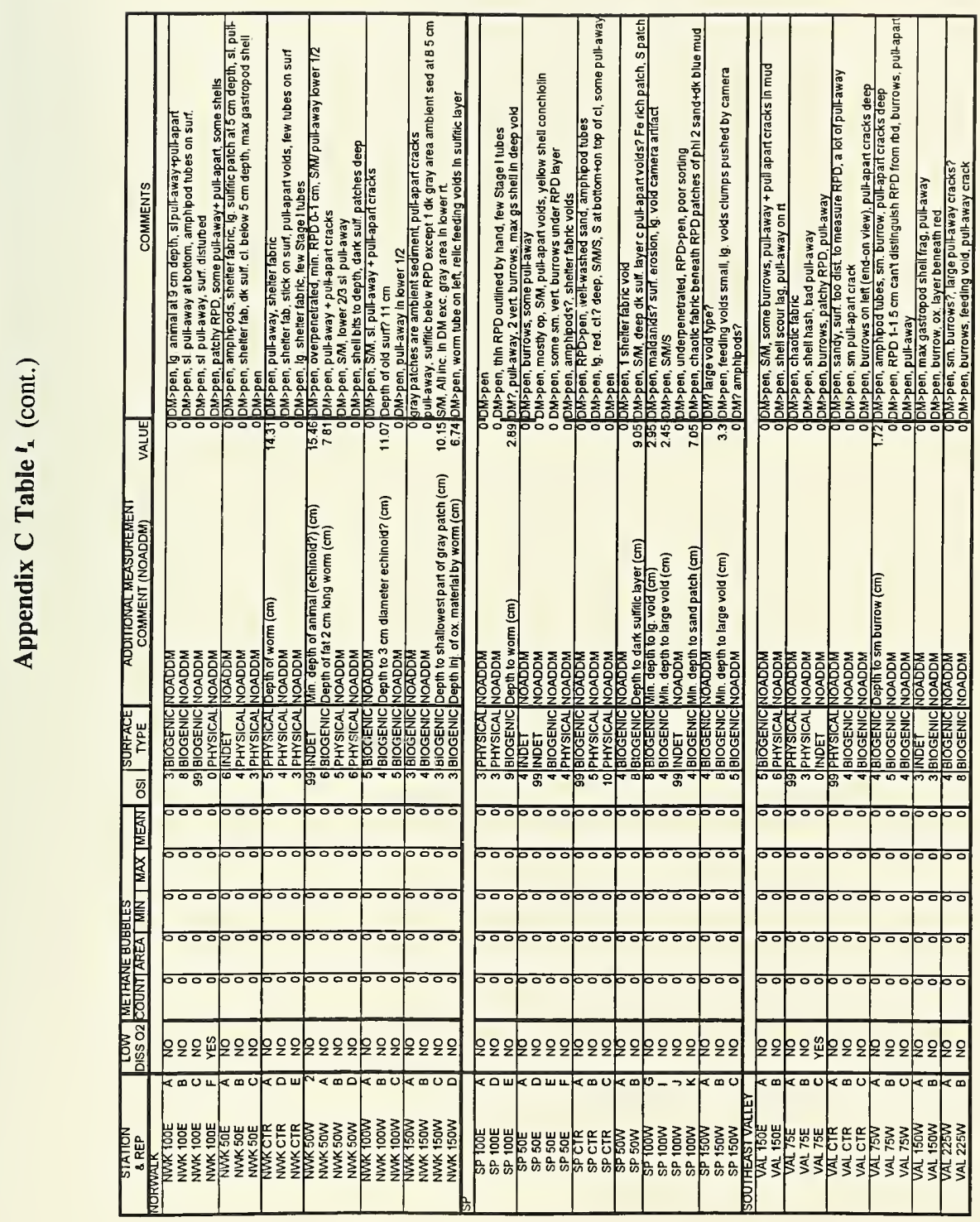




\section{Appendix C Table 2}

Dredged Material Thickness from REMOTS ${ }^{\circledR}$ Precap Survey (3-4 November 1993)

\begin{tabular}{|c|c|c|c|c|c|}
\hline Station & Rep & $\begin{array}{l}\text { at } \mathrm{N} \\
\mathrm{dg} \text { min }\end{array}$ & $\begin{array}{l}\text { Long W } \\
\mathrm{dg} \quad \text { min }\end{array}$ & $\begin{array}{l}\text { DMLAYER } \\
\text { (cm) }\end{array}$ & $\begin{array}{c}\text { Mean DM Layer } \\
(\mathrm{cm})\end{array}$ \\
\hline $550 \mathrm{E}$ & $\bar{A}$ & 419.093 & 77253.044 & ABSENT & \multirow{3}{*}{2.0} \\
\hline & $\mathrm{C}$ & 419.094 & 7253.050 & ABSENT & \\
\hline & D & 419.093 & 7253.042 & 6 & \\
\hline $475 E$ & $\bar{B}$ & $\begin{array}{|ll|}41 & 9.091 \\
\end{array}$ & $\begin{array}{|ll|}7253.103 \\
\end{array}$ & ABSENT & \multirow{3}{*}{3.3} \\
\hline & $\overline{\mathrm{D}}$ & $\begin{array}{|ll|}41 & 9.093 \\
\end{array}$ & 7253.100 & 3 & \\
\hline & $\bar{E}$ & 419.095 & 7253.095 & 7 & \\
\hline $400 E$ & $\mathrm{~A}$ & $\begin{array}{|ll|}41 & 9.095 \\
\end{array}$ & $\begin{array}{|ll|}72 & 53.157\end{array}$ & ABSENT & \multirow{3}{*}{9.7} \\
\hline & $\bar{B}$ & $\begin{array}{|ll|}41 & 9.092 \\
\end{array}$ & 7253.164 & 9 & \\
\hline & $\mathrm{C}$ & $\begin{array}{|ll|}41 & 9.094 \\
\end{array}$ & \begin{tabular}{|lll}
72 & 53.164 \\
\end{tabular} & 20 & \\
\hline $325 E$ & $\bar{A}$ & $\begin{array}{|ll|}41 & 9.091 \\
\end{array}$ & $72 \quad 53.215$ & 15 & \multirow{3}{*}{18.3} \\
\hline & $\mathrm{D}$ & $\begin{array}{|ll|}41 & 9.091 \\
\end{array}$ & $\begin{array}{|ll|}72 & 53.210 \\
\end{array}$ & 20 & \\
\hline & $\mathrm{E}$ & \begin{tabular}{|ll}
41 & 9.092 \\
\end{tabular} & 7253.207 & 20 & \\
\hline $325 \mathrm{~W}$ & $\bar{D}$ & $\begin{array}{|ll|}41 & 9.101 \\
\end{array}$ & $\begin{array}{|ll|}72 & 53.682 \\
\end{array}$ & 12 & \multirow{3}{*}{12.5} \\
\hline & $\bar{E}$ & $\begin{array}{|ll|}41 & 9.102 \\
\end{array}$ & 7253.685 & $\overline{13}$ & \\
\hline & $\mathrm{F}$ & \begin{tabular}{|ll}
41 & 9.103 \\
\end{tabular} & $\begin{array}{|ll|}72 & 53.687 \\
\end{array}$ & 12.5 & \\
\hline $400 \mathrm{~W}$ & $\mathrm{~A}$ & $\begin{array}{|ll|}41 & 9.095 \\
\end{array}$ & $\begin{array}{llll}72 & 53.727 \\
\end{array}$ & ABSENT & \multirow{4}{*}{8.2} \\
\hline & $\bar{B}$ & $\begin{array}{|ll|}41 & 9.092 \\
\end{array}$ & $\begin{array}{|lll|}72 & 53.723\end{array}$ & 6 & \\
\hline & $\bar{D}$ & $\begin{array}{|ll|}41 & 9.101 \\
\end{array}$ & 7253.736 & 9 & \\
\hline & $E$ & $\begin{array}{|ll|}41 & 9.106 \\
\end{array}$ & $\begin{array}{lll}72 & 53.738 \\
\end{array}$ & 9.5 & \\
\hline $475 \mathrm{~W}$ & $\bar{A}$ & $\begin{array}{|ll|}41 & 9.106 \\
\end{array}$ & 7253.789 & ABSENT & \multirow{4}{*}{4.3} \\
\hline & $B$ & $\begin{array}{|ll|}41 & 9.107 \\
\end{array}$ & 7253.789 & 1 & \\
\hline & $\mathrm{C}$ & $\begin{array}{|ll|}41 & 9.108 \\
\end{array}$ & $72 \quad 53.786$ & 1 & \\
\hline & $\bar{D}$ & 419.096 & $72 \quad 53.782$ & 11 & \\
\hline $550 \mathrm{~W}$ & $\bar{A}$ & $\begin{array}{|ll|}41 & 9.098 \\
\end{array}$ & $\begin{array}{llll}72 & 53.839\end{array}$ & ABSENT & \multirow{3}{*}{0.3} \\
\hline & B & 419.094 & $72 \quad 53.839$ & 1 & \\
\hline & C & $\begin{array}{|ll|}41 & 9.098 \\
\end{array}$ & $\begin{array}{|ll|}72 & 53.836\end{array}$ & ABSENT & \\
\hline $550 \mathrm{NE}$ & A & $\begin{array}{ll}41 & 9.302 \\
\end{array}$ & $72 \quad 53.167$ & ABSENT & \\
\hline & B & $\begin{array}{|ll|}41 & 9.302 \\
\end{array}$ & 7253.162 & ABSENT & \\
\hline & C & $\begin{array}{|ll|}41 & 9.309\end{array}$ & $\begin{array}{|ll|}72 & 53.162\end{array}$ & ABSENT & \\
\hline $475 \mathrm{NE}$ & $\mathrm{A}$ & $\begin{array}{|ll|}41 & 9.270 \\
\end{array}$ & $72 \quad 53.200$ & 10 & \multirow{3}{*}{9.7} \\
\hline & B & $\begin{array}{|ll|}41 & 9.278 \\
\end{array}$ & \begin{tabular}{|lll}
72 & 53.201 \\
\end{tabular} & 12 & \\
\hline & C & 419.282 & $\begin{array}{|ll|}72 & 53.198 \\
\end{array}$ & 7 & \\
\hline 400NE & $\bar{A}$ & $\begin{array}{|ll|}41 & 9.253 \\
\end{array}$ & $\begin{array}{lll}72 & 53.251 \\
\end{array}$ & 20 & \multirow{3}{*}{16.7} \\
\hline & B & $\begin{array}{|ll|}41 & 9.261 \\
\end{array}$ & 7253.236 & 15 & \\
\hline & C & $\begin{array}{|ll|}41 & 9.263 \\
\end{array}$ & 7253.236 & 15 & \\
\hline $325 \mathrm{NE}$ & $\mathrm{A}$ & $\begin{array}{|ll|}41 & 9.215 \\
\end{array}$ & $72 \quad 53.278$ & 20 & \multirow{5}{*}{19.4} \\
\hline & $B$ & $\begin{array}{|ll|}41 & 9.220 \\
\end{array}$ & 7253.276 & 20 & \\
\hline & C & $\begin{array}{|ll|}41 & 9.224 \\
\end{array}$ & 7253.269 & 17 & \\
\hline & $\mathrm{D}$ & $\begin{array}{|ll|}41 & 9.226 \\
\end{array}$ & 7253.276 & 20 & \\
\hline & $E$ & $\begin{array}{|ll|}41 & 9.227 \\
\end{array}$ & $72 \quad 53.278$ & 20 & \\
\hline $325 \mathrm{SW}$ & $\bar{A}$ & $\begin{array}{|ll|}41 & 8.969 \\
\end{array}$ & $\begin{array}{lll}72 & 53.604 \\
\end{array}$ & 11 & \multirow{4}{*}{15.5} \\
\hline & $\mathrm{B}$ & 418.975 & 7253.605 & 20 & \\
\hline & $\bar{C}$ & 418.979 & 7253.603 & 20 & \\
\hline & $\mathrm{D}$ & \begin{tabular}{|lll}
41 & 8.970 \\
\end{tabular} & 7253.605 & 11 & \\
\hline $400 \mathrm{SW}$ & $A$ & 418.948 & $72 \quad 53.644$ & 8.5 & \multirow{3}{*}{8.2} \\
\hline & $\mathrm{B}$ & 418.943 & 7253.630 & 7 & \\
\hline & C & 418.945 & 7253.637 & 9 & \\
\hline \multirow[t]{4}{*}{$475 S W$} & $\bar{A}$ & 418.912 & 7253.691 & ABSENT & \\
\hline & $\mathrm{B}$ & $41 \quad 8.912$ & 7253.685 & ABSENT & \\
\hline & $\mathrm{C}$ & 418.920 & 7253.683 & ABSENT & \\
\hline & D & $\begin{array}{|ll|}41 & 8.917 \\
\end{array}$ & 7253.682 & ABSENT & \\
\hline \multirow[t]{3}{*}{550 SW } & $\mathrm{A}$ & 418.888 & $72 \quad 53.717$ & ABSENT & \\
\hline & B & 418.890 & 7253.713 & CLUMP & \\
\hline & $C$ & 418.893 & 7253.710 & CLUMP & \\
\hline
\end{tabular}


Appendix C Table 2 (cont.)

\begin{tabular}{|c|c|c|c|c|c|c|c|}
\hline Station & Rep & $\begin{array}{l}\text { Lath } \\
d g\end{array}$ & $\min$ & $\begin{array}{l}\text { Long W } \\
\text { dg }\end{array}$ & $\min$ & $\begin{array}{l}\text { DMLAYER } \\
(\mathrm{cm})\end{array}$ & $\begin{array}{c}\text { Mean DM Layer } \\
\text { (cm) }\end{array}$ \\
\hline 550SE & A & 41 & 8.883 & 72 & 53.170 & ABSENI & \multirow{3}{*}{ 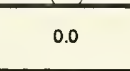 } \\
\hline & $B$ & 41 & 8.881 & 72 & 53.163 & ABSENT & \\
\hline & C & 41 & 8.888 & 72 & 53.163 & ABSENT & \\
\hline $475 \mathrm{SE}$ & A & 41 & 8.919 & 72 & 53.214 & ABSENT & \multirow{3}{*}{0.0} \\
\hline & $B$ & 41 & 8.922 & 72 & 53.210 & ABSENT & \\
\hline & C & 41 & 8.923 & 72 & 53.202 & ABSENT & \\
\hline $4005 E$ & $A$ & 41 & 8.952 & 72 & 53.244 & 8 & \multirow{3}{*}{8.0} \\
\hline & 8 & 41 & 8.954 & 72 & 53.239 & 8 & \\
\hline & C & 41 & 8.950 & 72 & 53.232 & 8 & \\
\hline $325 \mathrm{SE}$ & $\mathrm{A}$ & 41 & 8.977 & 72 & 53.280 & 17 & \multirow{3}{*}{13.0} \\
\hline & $B$ & 41 & 8.978 & 72 & 53.276 & 12 & \\
\hline & C & 41 & 8.974 & 72 & 53.264 & 10 & \\
\hline $325 \mathrm{NW}$ & A & 41 & 9.218 & 72 & 53.608 & 5.5 & \multirow{3}{*}{8.2} \\
\hline & 8 & 41 & 9.216 & 72 & 53.603 & 10 & \\
\hline & C & 41 & 9.215 & 72 & 53.600 & 9 & \\
\hline 400NW & $\bar{A}$ & 41 & 9.239 & 72 & $53 . \overline{4} 43$ & 4.5 & \multirow{3}{*}{4.7} \\
\hline & $B$ & 41 & 9.245 & 72 & 53.647 & 6.5 & \\
\hline & C & 41 & 9.249 & 72 & 53.646 & 3 & \\
\hline \multirow{3}{*}{$475 N W$} & A & 41 & 9.268 & 72 & 53.677 & $<1$ & \\
\hline & $\mathrm{B}$ & 41 & 9.276 & 72 & 53.685 & ABSENT & \\
\hline & C & 41 & 9.281 & 72 & 53.681 & ABSENT & \\
\hline \multirow[t]{3}{*}{$550 N W$} & $\bar{B}$ & 41 & 9.303 & 72 & 53.720 & ABSENT & \\
\hline & C & 41 & 9.310 & 72 & 53.719 & ABSENT & \\
\hline & $D$ & 41 & 9.252 & 72 & 53.722 & ABSENT & \\
\hline \multirow[t]{3}{*}{$500 N$} & $A$ & 41 & 9.393 & 72 & 53.440 & CLUMP & \\
\hline & $\bar{B}$ & 41 & 9.393 & 72 & 53.437 & CLUMP & \\
\hline & C & 41 & 9.393 & 72 & 53.435 & ABSENT & \\
\hline \multirow[t]{3}{*}{$475 \mathrm{~N}$} & $A$ & 41 & 9.351 & 72 & 53.444 & ABSENT & \\
\hline & $\bar{B}$ & 41 & 9.352 & 72 & 53.438 & PATCHY & \\
\hline & C & 41 & 9.352 & 72 & 53.435 & ABSENT & \\
\hline \multirow[t]{3}{*}{$400 N$} & $\bar{A}$ & 41 & 9.306 & 72 & 53.437 & 3 & \multirow{3}{*}{2.3} \\
\hline & $B$ & 41 & 9.311 & 72 & 53.435 & 2 & \\
\hline & C & 41 & 9.314 & 72 & 53.434 & 2 & \\
\hline \multirow[t]{3}{*}{$325 \mathrm{~N}$} & $\bar{A}$ & 41 & 9.272 & 72 & 53.441 & 4.5 & \multirow{3}{*}{6.2} \\
\hline & $B$ & 41 & 9.272 & 72 & 53.440 & 7 & \\
\hline & C & 41 & 9.271 & 72 & 53.440 & 7 & \\
\hline \multirow[t]{3}{*}{$325 \mathrm{~S}$} & $A$ & 41 & 8.915 & 72 & 53.436 & 11 & \multirow{3}{*}{7.2} \\
\hline & $B$ & 41 & 8.921 & 72 & 53.433 & 5.5 & \\
\hline & C & 41 & 8.922 & 72 & 53.435 & 5 & \\
\hline \multirow[t]{3}{*}{4005} & $\bar{A}$ & 41 & 8.878 & $\overline{72}$ & 53.441 & ABSENT & \\
\hline & $\bar{B}$ & 41 & 8.880 & 72 & 53.432 & 6 & 4.3 \\
\hline & C & 41 & 8.880 & 72 & 53.430 & 7 & \\
\hline 4755 & $\bar{A}$ & 41 & 8.834 & 72 & 53.438 & CLUMP & \\
\hline & B & 41 & 8.840 & 72 & 53.435 & ABSENT & \\
\hline & C & 41 & 8.842 & 72 & 53.437 & ABSENT & \\
\hline $550 \mathrm{~S}$ & $\bar{A}$ & 41 & 8.803 & 72 & 53.444 & ABSENT & \\
\hline & $B$ & 41 & $\begin{array}{l}8.802 \\
\end{array}$ & 72 & 53.441 & ABSENT & \\
\hline & C & 41 & 8.802 & 72 & 53.439 & ABSENT & \\
\hline 400WSW & $\bar{A}$ & 41 & 9.018 & 72 & 53.705 & 20 & \\
\hline & $\mathrm{B}$ & 41 & 9.021 & 72 & 53.709 & 20 & 20.0 \\
\hline & C & 41 & 9.021 & 72 & 53.699 & 20 & \\
\hline $400 S S W$ & $\bar{A}$ & 41 & 8.901 & 72 & 53.547 & ABSENT & \\
\hline & $\bar{B}$ & 41 & 8.901 & 72 & 53.543 & ABSENT & \\
\hline & C & 41 & 8.904 & 72 & 53.546 & ABSENT & \\
\hline
\end{tabular}




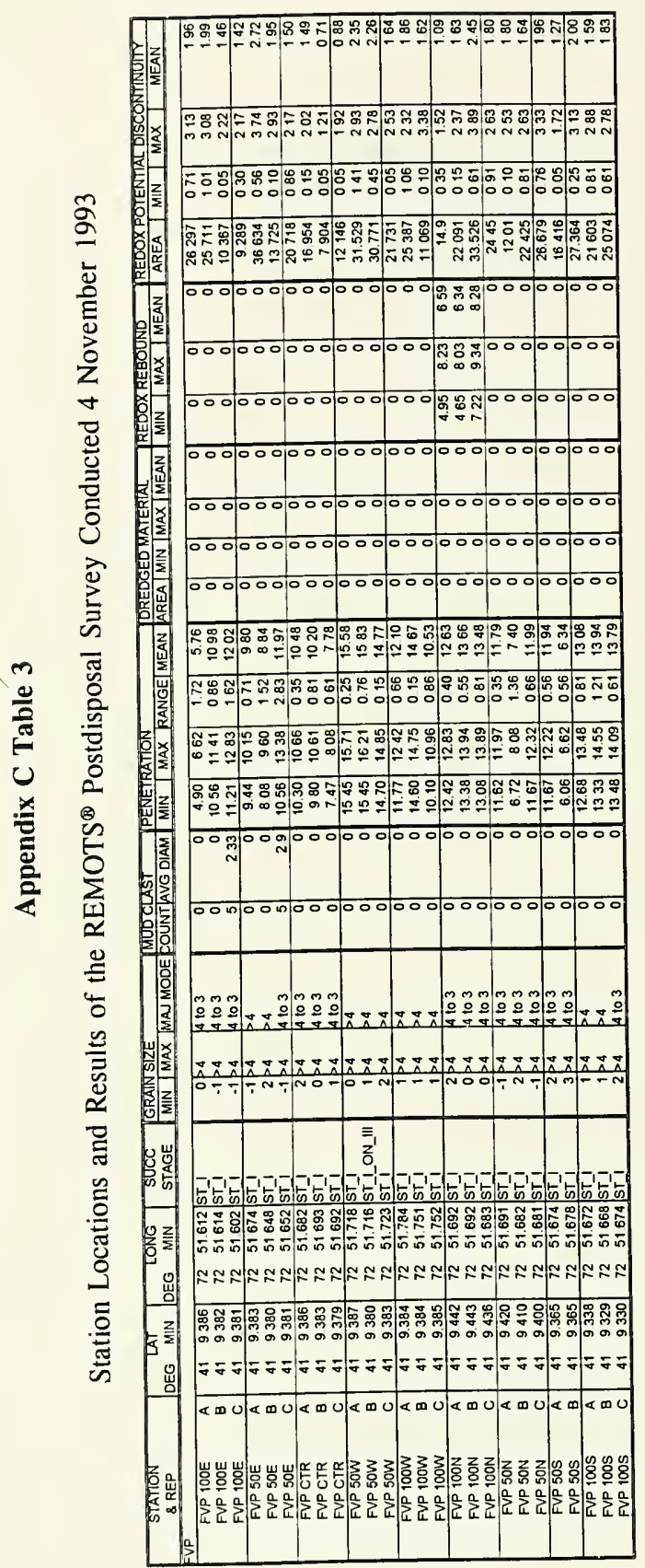




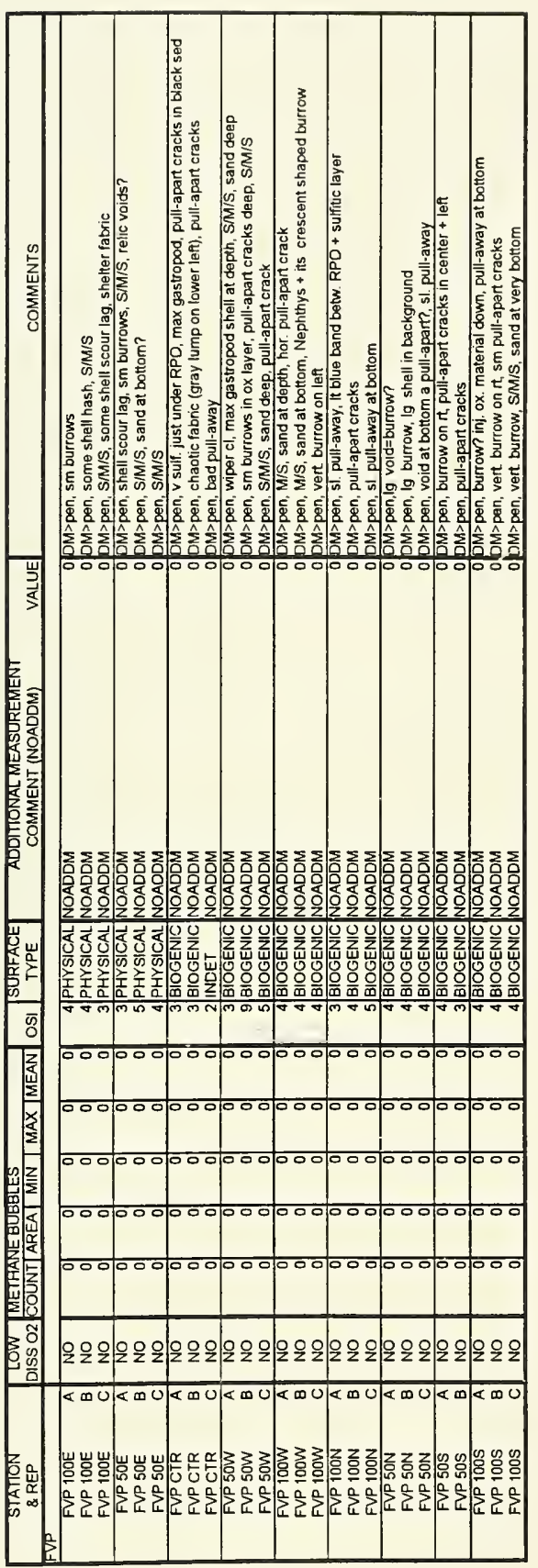



APPENDIX D

Sediment Cores and Grabs 



\section{Appendix D Sediment Cores and Grabs}

Appendix D Table 1.

Appendix D Table 2.

Appendix D Figure 1.

Appendix D Figure 2.

Appendix D Figure 3.

Appendix D Figure 4.

Appendix D Figure 5.

Appendix D Figure 6.

Appendix D Figure 7.

Appendix D Figure 8.

Appendix D Figure 9.
Location of Geotechnical Cores Collected for the New Haven Harbor Capping Project, September 1993 to March 1994

Location of Sediment Grab Samples Collected During the Interim Disposal and Interim Cap Surveys

Location of the geotechnical cores collected during the predisposal (baseline) survey, 21 September 1993

Location of geotechnical cores collected during the precap survey superimposed on the precap mound, 10 November 1993

Location of geotechnical cores collected during the postcap survey superimposed on the postcap mound, 15 March 1994

Time series of geotechnical cores collected in the southwest quadrant of the NHAV 93 mound .

Time series of geotechnical cores collected in the northeast quadrant of the NHAV 93 mound

Time series of geotechnical cores collected in the northwest quadrant of the NHAV 93 mound

Time series of geotechnical cores collected in the southeast quadrant of the NHAV 93 mound

Time series of geotechnical cores collected in the center of the NHAV 93 mound

Postcap geotechnical cores collected over the northeast and southwest flanks of the NHAV 93 mound 


\section{Appendix D Table 1}

Location of Geotechnical Cores Collected for the New Haven Harbor Capping Project, September 1993 to March 1994

\section{A. Predisposal Survey 21 September 1993}

\begin{tabular}{|llll|}
\hline Core & Latitude & Longitude & \\
\hline CLIS A & $41^{\circ} 09.091^{\prime} \mathrm{N}$ & $72^{\circ} 53.502^{\prime} \mathrm{W}$ & \\
CLIS B & $41^{\circ} 08.602^{\prime} \mathrm{N}$ & $72^{\circ} 53.923^{\prime} \mathrm{W}$ & $\begin{array}{c}* \text { located outside } \\
\text { the designated } \\
\text { work area }\end{array}$ \\
CLIS C & $41^{\circ} 09.181^{\prime} \mathrm{N}$ & $72^{\circ} 53.401^{\prime} \mathrm{W}$ & \\
CLIS D & $41^{\circ} 09.172^{\prime} \mathrm{N}$ & $72^{\circ} 53.534^{\prime} \mathrm{W}$ & \\
CLIS E & $41^{\circ} 09.081^{\prime} \mathrm{N}$ & $72^{\circ} 53.395^{\prime} \mathrm{W}$ & \\
CLIS F & $41^{\circ} 09.098^{\prime} \mathrm{N}$ & $72^{\circ} 53.442^{\prime} \mathrm{W}$ & $*$ unsuccessful, \\
& & & FF \\
CLIS FF & $41^{\circ} 09.142^{\prime} \mathrm{N}$ & $72^{\circ} 53.438^{\prime} \mathrm{W}$ & \\
\hline
\end{tabular}

B. Postdisposal/Precap Survey 10 November 1993

\begin{tabular}{|c|c|c|c|}
\hline Core & Latitude & Longitude & \\
\hline CLIS G & $41^{\circ} 09.086^{\prime} \mathrm{N}$ & $72^{\circ} 53.497^{\prime} \mathrm{W}$ & Replicate of Core A \\
\hline CLIS H & $41^{\circ} 08.607^{\prime} \mathrm{N}$ & $72^{\circ} 53.929^{\prime} \mathrm{W}$ & $\begin{array}{l}\text { Replicate of Core B } \\
\text { (outside designated } \\
\text { work area) }\end{array}$ \\
\hline CLIS I & $41^{\circ} 09.1785^{\prime} \mathrm{N}$ & $72^{\circ} 53.397^{\prime} \mathrm{W}$ & Replicate of Core C \\
\hline CLIS $\mathrm{J}$ & $41^{\circ} 09.168^{\prime} \mathrm{N}$ & $72^{\circ} 53.536^{\prime} \mathrm{W}$ & Replicate of Core D \\
\hline CLIS $\mathrm{K}$ & $41^{\circ} 09.080^{\prime} \mathrm{N}$ & $72^{\circ} 53.398^{\prime} \mathrm{W}$ & Replicate of Core E \\
\hline CLIS L & $41^{\circ} 09.132^{\prime} \mathrm{N}$ & $72^{\circ} 53.433^{\prime} \mathrm{W}$ & $\begin{array}{l}\text { Replicate of Core } \\
\text { FF }\end{array}$ \\
\hline CLIS II & $41^{\circ} 09.061^{\prime} \mathrm{N}$ & $72^{\circ} 53.520^{\prime} \mathrm{W}$ & $\begin{array}{l}\text { No replicate for } \\
\text { station }\end{array}$ \\
\hline
\end{tabular}




\section{Appendix D Table 2}

Location of Sediment Grab Samples Collected During the Interim Disposal and Interim Cap Surveys

A. Grabs Collected During the Interim Disposal Survey, October 25, 1993

\begin{tabular}{|lll|}
\hline $200 \mathrm{~W}$ & $41^{\circ} 09.165^{\prime} \mathrm{N}$ & $72^{\circ} 53.580^{\prime} \mathrm{W}$ \\
$100 \mathrm{~W}$ & $41^{\circ} 09.129^{\prime} \mathrm{N}$ & $72^{\circ} 53.511^{\prime} \mathrm{W}$ \\
$\mathrm{CTR}$ & $41^{\circ} 09.127^{\prime} \mathrm{N}$ & $72^{\circ} 53.454^{\prime} \mathrm{W}$ \\
$100 \mathrm{E}$ & $41^{\circ} 09.133^{\prime} \mathrm{N}$ & $72^{\circ} 53.379^{\prime} \mathrm{W}$ \\
$200 \mathrm{E}$ & $41^{\circ} 09.131^{\prime} \mathrm{N}$ & $72^{\circ} 53.304^{\prime} \mathrm{W}$ \\
$200 \mathrm{~N}$ & $41^{\circ} 09.238^{\prime} \mathrm{N}$ & $72^{\circ} 53.453^{\prime} \mathrm{W}$ \\
$100 \mathrm{~N}$ & $41^{\circ} 09.181^{\prime} \mathrm{N}$ & $72^{\circ} 53.452^{\prime} \mathrm{W}$ \\
$100 \mathrm{~S}$ & $41^{\circ} 09.079^{\prime} \mathrm{N}$ & $72^{\circ} 53.451^{\prime} \mathrm{W}$ \\
$200 \mathrm{~S}$ & $41^{\circ} 09.020^{\prime} \mathrm{N}$ & $72^{\circ} 53.451^{\prime} \mathrm{W}$ \\
\hline
\end{tabular}

B. Grabs Collected During the Interim Cap Survey, November 24, 1993

\begin{tabular}{|lll|}
\hline $200 \mathrm{~W}$ & $41^{\circ} 09.126^{\prime} \mathrm{N}$ & $72^{\circ} 53.585^{\prime} \mathrm{W}$ \\
$100 \mathrm{~W}$ & $41^{\circ} 09.136^{\prime} \mathrm{N}$ & $72^{\circ} 53.518^{\prime} \mathrm{W}$ \\
$\mathrm{CTR}$ & $41^{\circ} 09.132^{\prime} \mathrm{N}$ & $72^{\circ} 53.443^{\prime} \mathrm{W}$ \\
$100 \mathrm{E}$ & $41^{\circ} 09.117^{\prime} \mathrm{N}$ & $72^{\circ} 53.366^{\prime} \mathrm{W}$ \\
$200 \mathrm{E}$ & $-41^{\circ} 09.122^{\prime} \mathrm{N}$ & $72^{\circ} 53.284^{\prime} \mathrm{W}$ \\
$200 \mathrm{~N}$ & $41^{\circ} 09.229^{\prime} \mathrm{N}$ & $72^{\circ} 53.454^{\prime} \mathrm{W}$ \\
$100 \mathrm{~N}$ & $41^{\circ} 09.182^{\prime} \mathrm{N}$ & $72^{\circ} 53.436^{\prime} \mathrm{W}$ \\
$100 \mathrm{~S}$ & $41^{\circ} 09.067^{\prime} \mathrm{N}$ & $72^{\circ} 53.452^{\prime} \mathrm{W}$ \\
$200 \mathrm{~S}$ & $41^{\circ} 09.008^{\prime} \mathrm{N}$ & $72^{\circ} 53.437^{\prime} \mathrm{W}$ \\
\hline
\end{tabular}


Appendix D Table 1 (cont.)

C. Postcap Survey 15 March 1994

\begin{tabular}{|c|c|c|c|}
\hline Core & Latitude & Longitude & \\
\hline CLIS-MM & $41^{\circ} 09.173^{\prime} \mathrm{N}$ & $72^{\circ} 53.409^{\prime} \mathrm{W}$ & Close to CLIS-C, I \\
\hline CLIS-N & $41^{\circ} 09.141^{\prime} \mathrm{N}$ & $72^{\circ} 53.441^{\prime} \mathrm{W}$ & $\begin{array}{l}\text { Same location as } \\
\text { CLIS FF, L }\end{array}$ \\
\hline CLIS P & $41^{\circ} 09.070^{\prime} \mathrm{N}$ & $72^{\circ} 53.540^{\prime} \mathrm{W}$ & Close to CLIS-II \\
\hline CLIS Q & $41^{\circ} 08.990^{\prime} \mathrm{N}$ & $72^{\circ} 53.633^{\prime} \mathrm{W}$ & $\begin{array}{l}\text { SW flank of new } \\
\text { mound }\end{array}$ \\
\hline CLIS R & $41^{\circ} 09.254^{\prime} \mathrm{N}$ & $72^{\circ} 53.322^{\prime} \mathrm{W}$ & $\begin{array}{l}\text { NE flank of new } \\
\text { mound }\end{array}$ \\
\hline CLIS-SS & $41^{\circ} 09.093^{\prime} \mathrm{N}$ & $72^{\circ} 53.392^{\prime} \mathrm{W}$ & Close to CLIS-E, K \\
\hline CLIS-T & $41^{\circ} 09.177^{\prime} \mathrm{N}$ & $72^{\circ} 53.516^{\prime} \mathrm{W}$ & $\begin{array}{l}\text { Same location as } \\
\text { CLIS-J }\end{array}$ \\
\hline
\end{tabular}




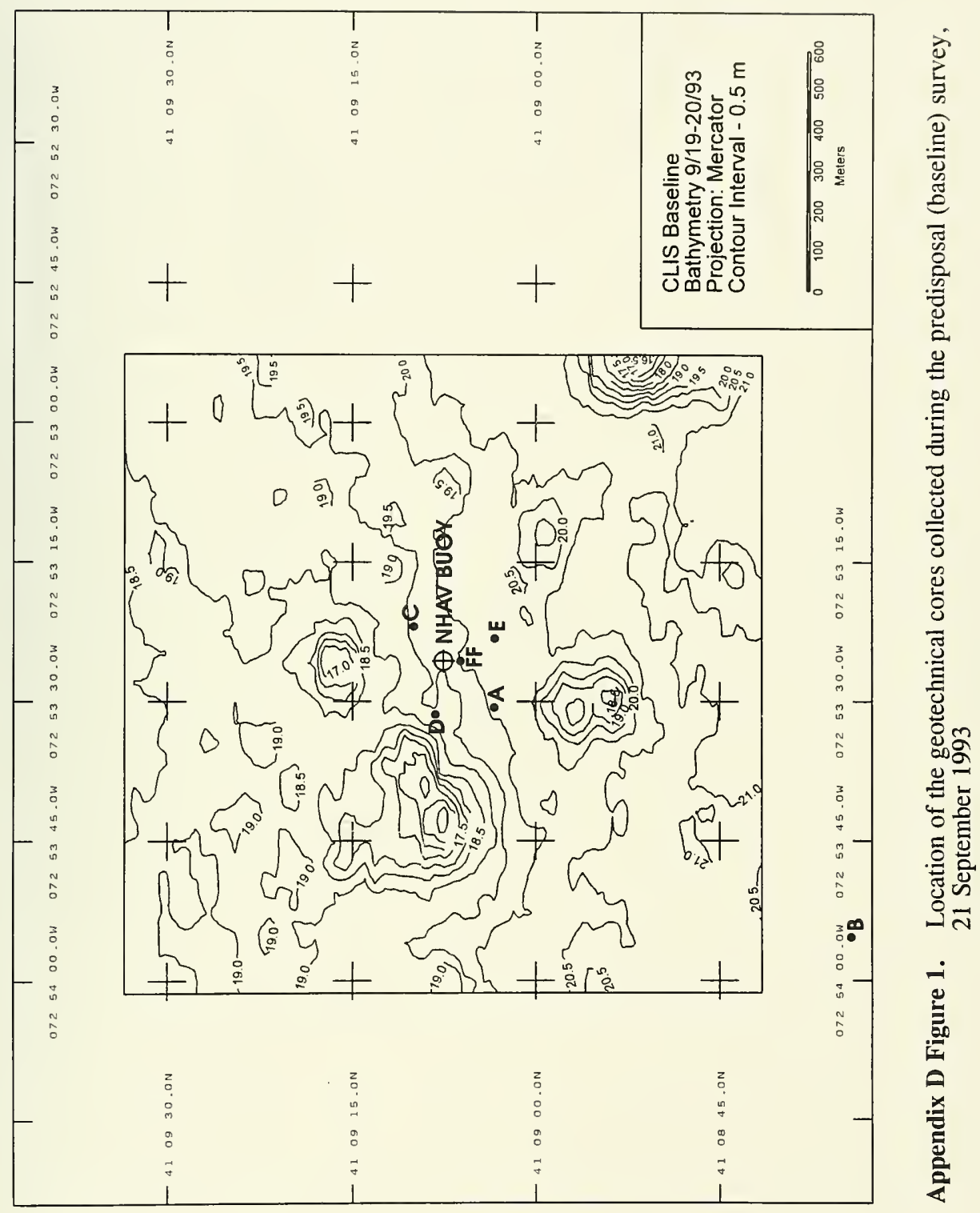




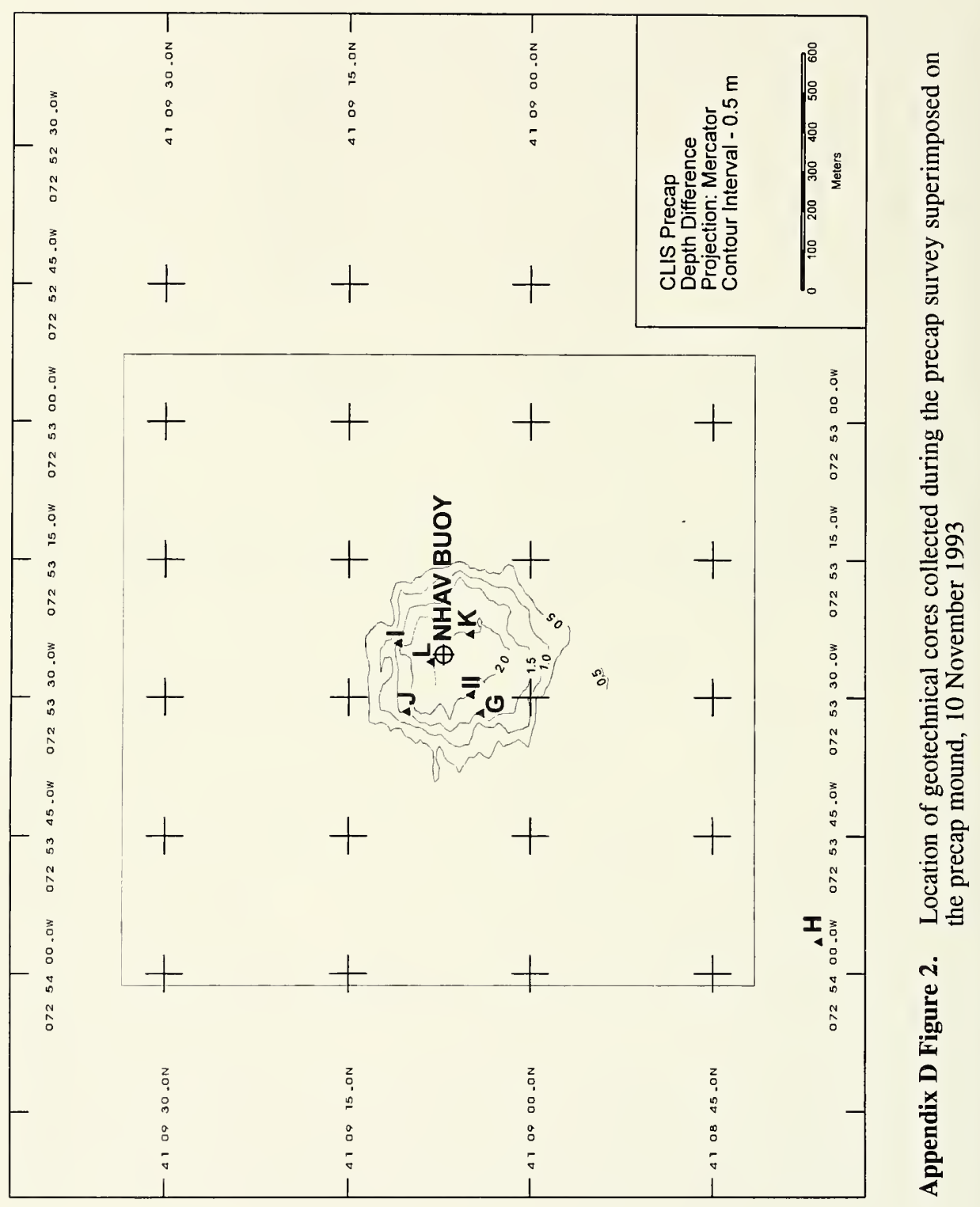




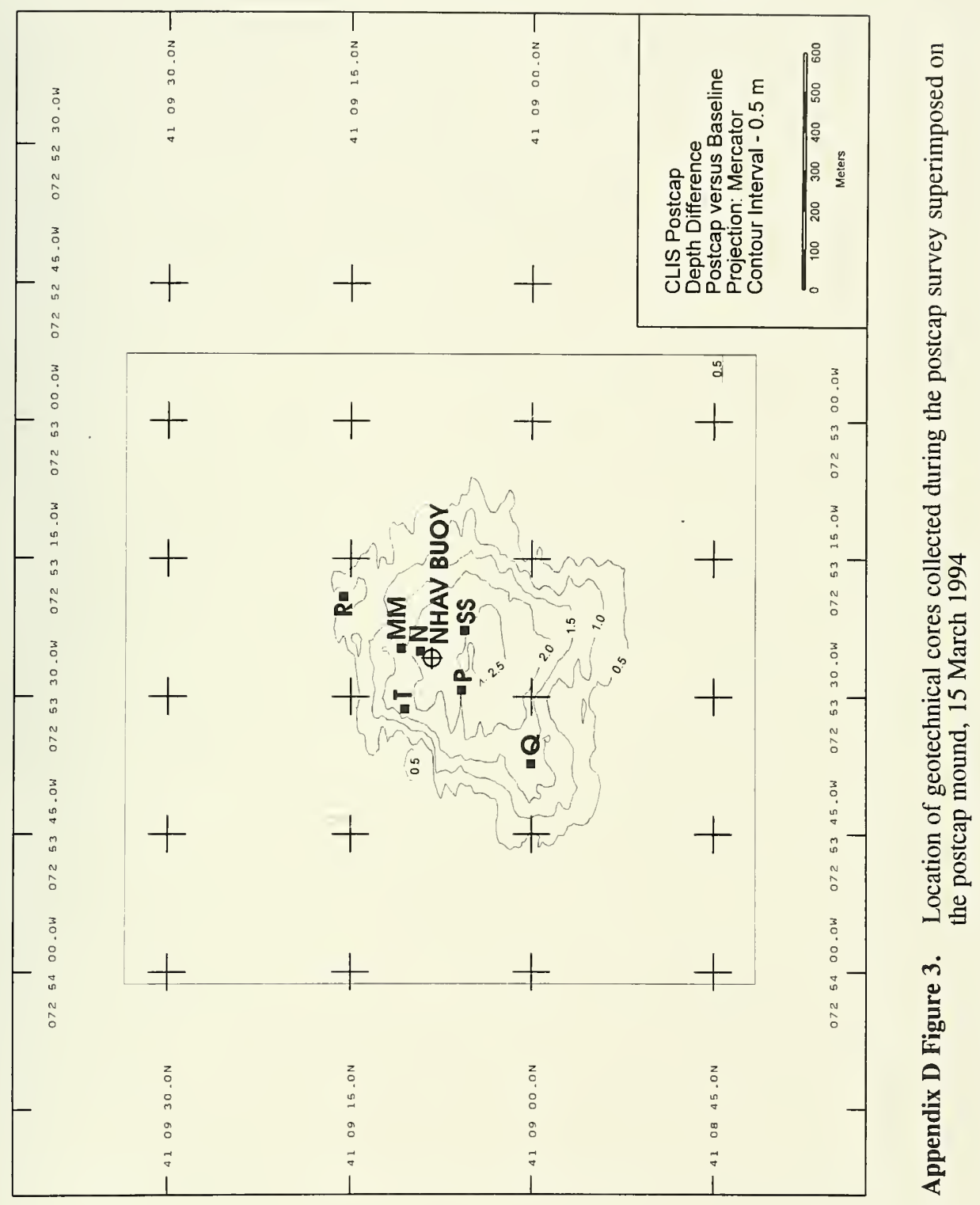




